\title{
THE LAW OF ONE PRICE OVER 700 YEARS
}

\author{
Kenneth A. Froot \\ Michael Kim \\ Kenneth Rogoff
}

Working Paper No. 5132

\section{NATIONAL BUREAU OF ECONOMIC RESEARCH 1050 Massachusetts Avenue \\ Cambridge, MA 02138 \\ May 1995}

The authors are grateful to David Backus, Hali Edison, Rudiger Dornbusch, Barry Eichengreen, Dick Marston, and Joel Mokyr for helpful comments, and to Katrien Hooyman and Arthur van Reil for assistance in constructing 19th century Dutch data. The authors are also grateful to the National Science Foundation, the Ford Foundation, and the Department of Research at Harvard Business School for financial support. Paul O'Connell provided superb research assistance. This paper is part of NBER's research programs in International Finance and Macroeconomics and International Trade and Investment. Any opinions expressed are those of the authors and not those of the National Bureau of Economic Research.

(C) 1995 by Kenneth A. Froot, Michael Kim and Kenneth Rogoff. All rights reserved. Short sections of text, not to exceed two paragraphs, may be quoted without explicit permission provided that full credit, including $\odot$ notice, is given to the source. 


\title{
THE LAW OF ONE PRICE \\ OVER 700 YEARS
}

\begin{abstract}
This paper examines annual commodity price data from England and Holland over a span of seven centuries. Our data set incorporates transactions prices on 8 commodities: barley, butter, cheese, eggs, oats, peas, silver, wheat as well as pound/shilling nominal exchange rates going back, in some cases, to 1273 . We find that the volatility and persistence of deviations from the law of one price have been remarkably stable over time. LOP deviations are highly correlated across commodities (especially at annual horizons) and, for most pairwise comparisons in most centuries, at least as volatile as relative prices across different goods within the same country. Our analysis challenges the conventional view that the modern floating exchange rate experience is exceptional in terms of the behavior of relative (exchange-rate adjusted) prices across countries.

Kenneth A. Froot

Harvard Business School

Soldiers Field

Boston, MA 02163

and NBER

Michael Kim

Department of Economics Pennsylvania State University 619 Kern Graduate Building University Park, PA 16802
\end{abstract}

Kenneth Rogoff

Woodrow Wilson School

Princeton University

Princeton, NJ 08544-1013

and NBER 


\section{Introduction}

One of the most striking empirical regularities in international finance is the volatility and persistence of deviations from the law of one price across relatively homogeneous classes of goods. Whereas goods market arbitrage may force virtually instantaneous international price equalization for precious metals such as gold and silver, price adjustment for most goods is relatively slow, with half lives for price deviations typically exceeding one year. For overall CPI and PPI indices, the half life of purchasing power parity deviations appears more on the order of three to four years. ${ }^{1}$

The general presumption among most international economists is that the volatility, if not the persistence, of international price and real exchange rate deviations is a relatively modern phenomenon, reflecting a combination of domestic price rigidities and high nominal exchange rate volatility. We show here that this is not the case; the volatility of deviations from the law of one price has been no larger in the twentieth century than in the fourteenth. Several alternative measures all suggest that with the possible exception of the late 19 th and early twentieth centuries, the volatility of law of one price deviations has generally been remarkably stable by century over the second millennium. Moreover, because our data also reveal a large common component in deviations from the law of one price across goods, they suggest that much of the volatility and persistence we document applies to real exchange rates computed on broad indexes and not just to cross-country relative prices of individual goods.

Our data set, which we describe in section 2, consists of annual price observations on a variety of agricultural commodities for Holland and England, going back in some cases to the 13 th century. The sheer length of the data set is, of course, interesting in its own right. With seven centuries of data, one can potentially say much more about low frequency characteristics of the data than is normally the case. Interestingly, we find that intra-country relative price trends among the various goods included in our data set are

\footnotetext{
${ }^{1}$ Isard (1977) finds large persistent deviations from the law of one price in seven-digit SITC categories; Giovannini (1988) finds similar results even for extremely homogenous categories of goods such as screws. Other recent papers documenting the size of law of one price deviations include Engel (1993), Rogers and Jenkins (1995) and Engel and Rogers (1994). For a survey of this literature and the broader literature on purchasing power parity, see Froot and Rogoff (1995).
} 
small, even for comparisons including silver. Cross-country trends in the relative price of the same goods (law of one price deviations) are insignificant over the full sample, but can be quite large within any given century. These century-long swings appear to be highly correlated across goods, regardless of their apparent tradability. That is, when the relative price of wheat is high in England relative to Holland, the relative price of eggs tends to be high as well. One rationale is that what we refer to as 'traded' goods often embody a substantial nontraded component by the time they are delivered to a purchaser.

Our data description in section 2 is supplemented by an appendix containing an annotated bibliography of the major references used in our data construction, as well as a detailed description of the data by commodity and by year. Section 3.1 gives a graphical depiction of the core series, and section 3.3 constructs various measures of trends. These measures differ depending on how one accounts for the host of wars and plagues that took place over this long historical time span. Section 3.4 contains our central results on volatility. We find that regardless of how one controls for plagues, wars and trends, the volatility of law of one price deviations is both remarkably high (typically on the order of $20 \%$ or more per year for most commodities in most centuries) and remarkably stable over time. We find, in fact, that the volatilities of law of one price deviations are generally at least as large, if not larger, than the volatilities of relative prices of different goods within the same country. ${ }^{2}$

To estimate the persistence of law of one price deviations, and to test for unit roots, it is necessary to confront the problem of missing observations. We deal with this problem in section 3.5 using a Kalman filter approach, simultaneously projecting the missing data and forming our time series estimates. The approach is discussed in the technical appendix. We find levels of persistence in price deviations over the time period to be very similar to those reported in the literature for the twentieth century and, indeed, we cannot reject the hypothesis that the degree of persistence has not changed in the twentieth century or after the start of the modern float in 1973.

In our conclusions, section 4 , we assess our main results and consider some possible extensions.

\footnotetext{
${ }^{2}$ Engel (1993) and Engel and Rogers (1994) have emphasized this fact for data from the modern (post-1973) float.
} 


\section{Data Description}

Our data set consists of annual wholesale prices for Holland and England for eight commodities, spanning the late 13th century to the present day. The commodities include three grains (wheats, oats and barley), three dairy products (butter, eggs and cheese), peas, and silver. Coverage varies somewhat over time and across commodities, as figure 1 illustrates. The grain and market silver price series are quite solid with very few missing observations. In contrast, the dairy price data for England generally begin only in the mid-sixteenth century (Dutch data begin earlier), with a number of missing observations thereafter.

\subsection{Data sources}

The core references for the pre-19th century data are two studies which grew out of the International Commission on Price History, a project headed by Lord William Beveridge (of Beveridge curve fame) that began in the 1930s. Beveridge's (1939) book on England mainly covers the mid-sixteenth century through the eighteenth century, whereas Posthumus's two books (1946, 1964) on Holland cover mainly the late fourteenth century through the early nineteenth century. Thanks in part to the coordinating efforts of the Commission, there is a significant correspondence in methodology across the two studies.

Although the Beveridge project volumes fill in several centuries of data, they still leave the earliest and most recent centuries of our sample period uncovered. The two main sources for early middle ages data are Thorgold Rogers (1866) for England, and Herman Van der Wee (1963) for Holland. As the first appendix details, for many commodities including especially the grains and silver, one can find multiple data sources even for the early years. The availability of multiple sources provides, of course, a helpful check on the data. The Beveridge and Posthumus books themselves provide duplicate price quotes for some commodities.

How do economic historians construct price data for the middle ages? In some cases, the prices are based on records from town markets or, for later periods, from organized exchanges. But by far the most important sources are the purchasing records of various institutions such as hospitals, colleges, orphanages, and the military. Though such data are not posted market 
prices, they are actual transactions prices paid by bulk purchasers. The first appendix lists many of the primary sources underlying the data, though of course the interested reader should turn to our various secondary sources for a more detailed data description.

The data for the past two hundred years come from a variety of sources, including back issues of The Economist, annual tables in the Journal of the Royal Statistical Society, Mitchell and Deane (1962), Mitchell and Jones (1971), and government statistical abstracts. Curiously, price data on nineteenthcentury Holland has, until recently, been extremely sparse. Fortunately, recent work by Knibbe (1993) and van Reil (1994) has filled in some of the major gaps. For the nineteenth and twentieth century, most of the data are wholesale market prices, though for nineteenth century Holland, some still comes from institutional transactions records.

\subsection{Caveats: location, averaging procedures, homo- geneity of goods}

Although the data seem reasonably reliable, the reader must be aware of a host of caveats when trying to interpret our later time series results. First, prices come from a variety of different locales within each country. For England, all prices are either from London or from institutions in nearby southeastern England. For Holland, the distances are greater. Amsterdam, of course, was not the major trading center until the 1500s. Before that, Utrecht was the commercial capital of Holland and some of our early price observations come from there. Dutch prices for the early middle ages are from Flanders and Brabant, which were economically integrated with Holland from the time of the Holy Roman Empire until Holland gained its independence from Spain at the end of the sixteenth century. After the 1500 s, virtually all of the data is from Amsterdam. Fortunately, the significant amount of overlapping data we have from the various markets suggests that price variation across markets within the same country are small compared to price variation we will later observe across commodities and countries (where differentials in excess of $20 \%$ are the norm).

Second, the annual data points for each commodity are actually averages of prices recorded throughout the year, with the method of averaging differing somewhat across studies. Not surprisingly, there is considerable controversy 
among historians on this issue. Beveridge criticizes Rogers for placing the same weight on individual transactions data as on price observations from town markets and large regular institutional purchasers. Rogers, in contrast, argues that any price that represents an arm's length transaction is a valuable piece of information.

Third, in addition to the problem of having shifting locales, one must recognize that none of the commodities we study are perfectly homogeneous. There are, for example, many different varieties of wheat. Posthumus provides prices for Konigsberg wheat, Polish wheat, red wheat, Warder wheat, Frisian wheat, and Zealand wheat. 'Barley' includes summer barley, winter barley, brewing barley and fudder barley. Beveridge notes that during bad harvest periods, the average quality of grains sold in town markets generally tends to drop. Again, our data suggest that the price variations across different kinds of the same commodity tend to be small relative to variations across different commodities and countries. Our general procedure for handling multiple data sources and commodity types was to take a simple average of the available data for any given commodity in any given year. (Sources for the raw data are listed in the first appendix.) Because the price variations across similar commodities and across intra-country data sources are relatively small, our main results appear fairly robust to the choice of averaging procedure.

\subsection{Other issues in data construction}

It should be noted that direct trade between Holland and England in the commodities listed here was quite limited over most of the period. Holland, for example, imported wheat from Germany, Austria, and Poland; see Posthumus (1946). Imports from England included mainly tin and lead, and exports to England included linens and spices. Thus any arbitrage to enforce the law of one price came mainly through third parties. ${ }^{3}$ Technology diffusion, of course, can also help equate relative prices, though over much longer periods.

\footnotetext{
${ }^{3}$ During the late 16 th to early 18 th centuries, the Netherlands served as a major entrepot port, with the Dutch being, by far, the dominant bulk carrier and merchant fleet. Thus, while direct trade between Holland and England in many commodities was limited, many international shipments of these goods transitted through Holland.
} 
Generally speaking, our tests for the law of one price involve converting nominal prices to silver prices within each country, and then comparing silver prices across countries. This approach is necessary as data on exchange rates is quite limited before the 1500 s, whereas local-currency prices for silver are relatively easily obtained. For the post- 1500 period where guilder-shilling exchange rates are available, deviations from the law of one price in silver for our data set appear to be extremely small (typically less than one percent). ${ }^{4}$ One could, of course, also use gold as the numeraire. In choosing silver, we follow the lead of the Beveridge Commission.

The prices we use are generally producer (wholesale) prices, inclusive of taxes. Beveridge and Posthumus provide enough information to remove taxes for some years for some series, but since the law of one price is generally tested inclusive of taxes we leave them in. There are other caveats. Beveridge, for example, notes that military purchasers were notoriously delinquent in making payments and no inflation or interest adjustment is made in the data to allow for this. It was not uncommon during the middle ages for the families of hospital patients to pay bills in kind with grains, so some (small) percentage of the prices drawn from early hospital records may not really represent arm's-length transactions, and the historians may not always have been successful in weeding out such cases.

Finally, we should mention that our choice of countries and commodities was largely dictated by our goal of putting together the longest possible time series for testing the law of one price. After silver and gold data, grain data is by far the deepest and most complete. Our decision to include dairy commodities such as eggs, where data become available only much later, was dictated by a desire to have a spectrum of tradeability across the different goods considered. Trade in eggs was presumably far more difficult than trade in wheat, at least prior to modern refrigeration and packing techniques. If one is willing to start from the late $1600 \mathrm{~s}$, it would be possible to test the law of one price across a much broader range of goods than we do here. Our view was that it was especially interesting to focus first on commodities for which really long time series are available.

In sum, a time series of this length must be spliced together from a vari-

\footnotetext{
${ }^{4}$ Even silver is not quite homogenous. Dutch prices tend to be quoted for fine silver versus standard silver for British prices. The relative price within each country between standard and fine silver was quite stable over the period, however, at .925 (see Jastram (1981)), so all prices were converted to standard silver.
} 
ety of sources encompassing a range of market locales and subtle variations in commodity types. We will argue, though, that these imperfections are generally second-order compared to the huge swings one observes over time for relative prices of distinct commodities, and for price differentials across different countries for the same commodity.

\subsection{Wars and Plagues}

Over such a long sample period, there are a plethora of major events one might want to control for in forming inferences about law of one price deviations. England and Holland fought countless wars over the sample period, sometimes independently, sometimes as allies, sometimes as enemies. Clearly wars are special events that might disrupt integration; this is certainly the case in the modern era. One also has to consider the effects of the scores of plagues that ravaged Europe during the middle ages, more than once eliminating sizable fractions of England and Holland's populations. Again, sometimes plagues occurred concurrently in the two countries, sometimes not. It is, of course, not obvious how plagues would affect price deviations. Did they have a greater effect on demand or supply? Our approach to dealing with plagues and wars is agnostic. We use dummy variables to control for war/plague effects, and to test the robustness of our results. (The notes to tables A1 and A2 at the end of the paper list the various major war and plague episodes.)

\section{Testing and Results}

Our approach to analyzing the data proceeds in increasing order of manipulation. First, we present graphs for a variety of relative prices. Because of the unusually extensive time span covered here, these graphs prove quite revealing. Second, we explore a number of measures of conditional price trends across alternative relative prices and sample periods. Third, we look at simple measures of the volatility of prices, conditioning only on trends, constants, and plague/war dummies. Finally, we look at some simple timeseries specifications for the behavior of relative prices over the full sample period as well as a number of sub-periods.

In order to conserve space, many of the results below focus on barley, 
butter, oats, silver, and wheat. We mention important differences across the omitted commodities where appropriate.

\subsection{Graphical results}

Figures 2 and 3 show the (log) prices of barley, oats, and butter relative to silver in England and Holland, respectively. In the graphs, an upward movement denotes a rise in the value of the good relative to silver. Not surprisingly, the two figures reveal clear evidence of a large common lowfrequency component, both across goods and countries. For example, the logs of goods prices relative to silver rose by about 1.50 (or about $450 \%$ ) from 1525 to about 1600 . After that, there is no clear trend until the 18 th century.

Historians have articulated two primary causes for this century-long surge in prices relative to silver. ${ }^{5}$ The first main cause was the discovery of massive silver deposits in the Americas, including especially the 1545 Potosi discovery in modern-day Peru. Combined with improved mining techniques, these new lodes produced a sharp increase in European silver stocks, with growth peaking during the 1590s. The second cause was the rapidity of population growth after the Black Plague of the mid-15th century. As additional lower quality lands had to be farmed to meet increased demand, prices of agricultural products rose. ${ }^{6}$

Prices in terms of silver grew by a similar amount in the late 19 th and early 20 th centuries as private silver stocks grew again, this time due largely to the discovery of the Comstock lode in Nevada in 1859 and the progressive demonetization of silver during the latter part of the century.

It is interesting to note that, while the value of silver in terms of agricultural goods has risen sharply since World War II, it has fallen over much of the past millennium. Today, barley, oats, and wheat are worth on average about 4.5 times as much silver as they were in 1273 . Of course, over seven hundred years, this amounts to only 21 basis points per year. Long-term rel-

\footnotetext{
${ }^{5}$ For good overviews of European history during much of this period, see Garraty and Gay (1972), Palmer and Colton (1978), and Cameron (1993).

${ }^{6}$ One problem with this hypothesis is that, holding silver stocks constant, the per capita supply of silver falls with increases in population. This effect would tend to lower the prices of grains relative to silver, and it is unclear whether the supply of grains was sufficiently inelastic to dominate it.
} 
ative price movements among the various agricultural goods is even smaller. One might conclude from the constancy of relative prices over very long horizons that there is a substantial degree of convergence in productivity across different commodities. If so, this would provide support for the view that technological innovation responds endogenously to price differentials, if only sporadically and only over very long time periods.

Figures 4 and 5 show the value of barley and oats relative to wheat (in logs) within each country. Our main interest in intra-country relative prices (across different goods) will be as a frame of reference for evaluating crossborder deviations in prices across similar goods. Both figures again show impressive amounts of both high- and low-frequency variability, although the low-frequency fluctuations appear to be smaller when wheat is the numeraire than when the numeraire is silver as in figures 2 and 3 . This is to be expected if agricultural goods face common low-frequency shocks to supply and demand (e.g., population growth, changes in eating habits, productivity, etc.)

We next use the data to examine deviations from the law of one price (henceforth LOP) over the sample. Figures 6-8 show the disparity between British and Dutch prices (in logs) for barley, oats, and butter, respectively. Here an upward movement in the graph denotes a rise in British relative to Dutch prices (after converting both sets of prices to a common numeraire.) As we have already discussed, our interpretation of these prices assumes that the law of one price holds for silver (since our data set does not include exchange rates for the early middle ages), but this appears to be a very good approximation over the period from the 1500 s on where exchange rate data is available.

The most remarkable characteristic of figures 6-8 is the volatility of LOP deviations. This volatility is very large - a simple year-to-year standard deviation of 0.25 in logs is not unusual in the earlier part of the sample. Casual inspection of the figures suggests that there are no large trends in LOP deviations over the full period. However, there do appear to be lowfrequency movements at one- to two- century time intervals.

A comparison of the three figures suggests that the relative price movements are highly correlated across the three goods, at least at frequencies of one or two centuries. (The figures are less useful for discerning whether there are high frequency correlations. We investigate later the presence of year-to-year deviations from the law of one price which are common across 
goods.) When the relative price of oats is persistently high in England, English prices of other goods tend to be persistently high as well. What kind of model might explain these LOP deviation correlations across goods at low frequencies?

The Balassa-Samuelson model (see Froot and Rogoff (1995)) posits that the relative prices of nontraded goods will tend to rise in the country with faster income growth. Indeed, the fluctuations evident in figures 6-8 accord well with relative GNP growth movements across the two countries. Specifically, the rise of Amsterdam as a major commercial center culminates around 1609, when under the 12 Year Truce between Spain and Holland, the port of Antwerp was effectively cut-off. This rise might explain the (slight) negative relative price trends to 1609 . After that, Holland's fortunes fell relative to those of the English. By 1713, Holland had basically exhausted herself fighting wars against France, allowing Great Britain to build herself into the world's main naval power. Holland was still a major financial and trade center and an important source of foreign capital but its relative position declined as Great Britain developed rapidly. The industrial revolution in England started somewhat later, circa 1760 (e.g., James Watt invented his steam engine in 1769). Interestingly, our data show that the industrial revolution had less of an effect on deviations from the LOP than did England's earlier commercial and political ascendancy. Figures 6-8 also suggest that English-to-Dutch prices fell from about 1825 on. At that time, Britain had become the richest country in the world, but its growth began to be eclipsed by other European countries. It is interesting to note in figures 6-8 that low-frequency deviations from the law of one price appear on a one-or-two century basis, but that these deviations appear to revert over the long run. ${ }^{7}$

One problem in interpreting the graphs as providing support for BalassaSamuelson is the cross-sectional evidence. Specifically, one typically would assume that the grains are more tradable than the dairy products, yet the figures suggest that deviations from the law of one price behave similarly across goods. One partial explanation of this phenomenon is that all the goods, once delivered to the local purchaser, embody substantial nontraded

\footnotetext{
${ }^{7}$ Trend long-run law of one price deviations are possible across goods containing a nontraded component, but only if there are trend productivity differentials between the two countries (see Froot and Rogoff (1995)). Given that Holland and England had roughly similar cumulative growth rates over the full sample, the long-run price convergence is perhaps not surprising.
} 
components in the form of storage, transport, etc.

Our data also provide some perspective on the Baumol-Bowen (1966) effect, which relates the evolution of relative prices to differences in productivity growth (i.e., more rapid productivity growth results in secular price declines). Baumol and Bowen argued that as a rule, productivity growth is slower in more labor intensive goods. Figures 9 and 10 depict the behavior of the log price of wheat relative to butter, cheese, and eggs. These log relative prices have risen by a factor 1.2 during the sample, an increase of $330 \%$ in the relative price levels since the 15 th century. Assuming that dairy production is more labor intensive than grain production, this price rise is broadly consistent with the Baumol-Bowen view. (Recently, this trend has reversed, partly due to the increased mechanization of dairy farming.)

A final interesting issue is the extent to which deviations from LOP are associated with nominal exchange rate fluctuations as opposed to fluctuations in local currency prices (holding constant for the moment any covariance between the two). Figure 11 compares the nominal shilling-guilder exchange rate with the ratio of English-to-Dutch local prices of wheat. This later ratio can be interpreted as the shilling-guilder exchange rate implied by the LOP in wheat.

From figure 11, we see that for the nominal exchange rate the early period prior to about 1600 was quite turbulent, ${ }^{8}$ that the period between approximately 1600 and 1930 was relatively quiescent, and that the post-1930 period became turbulent again, with the post-Bretton-Woods period being extremely so. Interestingly, from 1600 until the late 20 th century, the variability in local-currency prices was very large, accounting for the majority of deviations in the law of one price. However, beginning in the mid 19th century, and carrying over to today (and especially through the 1973-91 floatingrate period), the variability of local-currency prices has fallen dramatically, and the variability of the nominal exchange rate has increased dramatically. In other words, today more than ever before, nominal local-currency prices appear sticky and currency movements are large. To the extent that localcurrency prices are sticky (as has been argued by Engel (1993) and Engel and Rogers (1994)), such stickiness appears to have emerged only in the last

\footnotetext{
${ }^{8}$ The guilder was introduced in 1544, replacing the Flemish groat (at 40 groats per guilder), whose metal content had for some time experienced considerable instability (see Van Der Wee (1963) and Posthumus (1964)). Prior to 1544, our nominal exchange rate series uses the silver content of the groat.
} 
century or so.

Thus, while the volatility of deviations from LOP has not changed conspicuously from century to century over the last 700 years, the composition of these deviations has changed very dramatically. Note also, that if anything, LOP deviations appear less volatile over the past twenty years than over the bulk of the sample, despite the volatility of nominal exchange rates.

This is about as far as one can go using visual metrics. The next section attempts to characterize some basic statistical properties of the data.

\subsection{Methodology}

We next turn to looking at simple measures of trends and volatilities. Obviously, a data set of this length allows one to contemplate implementing the most extravagant time series techniques, but it seemed to us that in a first pass at the data, it would be useful to focus first on relatively transparent statistics. The first difficult issue, mentioned in section 2.4 , is how to deal with plagues and wars.

Though it would be interesting to study the effects of plagues and wars themselves, for our purposes they are nuisance effects. Our primary interest lies in providing robust estimates of price trends, variability, and dynamics in the absence of such events. However, it is not at all apparent a priori whether our base specification should control for wars and plagues and, if so, how. The presence of so many plausible potential dummy variables is an invitation to a specification search. We therefore pursue a strategy similar to that suggested by Leamer (1983), which avoids overemphasizing the results from a single specification, and helps illustrate the robustness of our main results. We consider a few simple methods of handling the multitude of plagues and wars, including the use of transitory and permanent dummies. The latter represent a crude attempt to capture dynamics in the effects of scourges, one that obviously serves as a better device in our century-long regressions than in our regressions over the entire time period. However, rather than present a filtered or iterated version of our results across these different plague/war specifications (which is the standard procedure), we report averaged results across the full universe of specifications we considered. Thus we report: $a v-$ erage coefficient estimates (e.g., trend, volatility, etc.) across the universe of trial specifications, average GLS standard errors of these coefficients, and the empirical standard deviation of the coefficient estimates across specifi- 
cations within the universe. These latter two statistics provide a sense of statistical significance both across all specifications and for individual specifications drawn at random. This procedure seemed to us a way of presenting a large amount of information without either detailing the copious results for our entire universe or committing to any single specification for treating nuisance effects. Generally speaking, our main results concerning volatility and persistence appear quite robust to the alternative treatments we considered of wars and plagues.

In notes to the tables reported below, we label as 'transitory' those dummies that are nonzero only during a plague or war event period. By contrast, what we call 'permanent' dummies become nonzero when a plague or war commences, but then remain nonzero for the rest of the sample. The permanent dummies better pick up persistent effects that major plagues and war are likely to exhibit.

To avoid identification problems (many plagues and war overlap one another), we combined transitory dummies into single 'plague' and 'war' dummies. Each of these takes on the value of 1 or -1 during the occurrence. The sign for each plague or war was determined in a prior stage in which we regressed of prices on transitory dummies for individual wars and plagues and observed the sign of the estimated dummy coefficient. Again the volatility and persistence results appear quite robust to this procedure. Fundamentally, plagues do not appear to have any obvious systematic effect on deviations from the LOP, and wars only appear to have a striking effect beginning with the Napoleonic wars in the early 19 th century. $^{9}$

\subsection{Trends in Relative Prices}

We look at trends both over the entire sweep of the data sample, and over individual centuries. Trend increases over different subsamples are important because they reveal something about low frequency fluctuations in the data. Of course, being able to detect low-frequency movements in the data is one of the great benefits to having 700 annual observations.

For the purposes of estimating trends, our universe of specifications consists of regressions of relative prices on: i) a constant and time trend; ii)

\footnotetext{
${ }^{9}$ Rogers (1994) presents evidence that in more modern times, wars do affect the time series behavior of relative prices. Specifically, he finds that PPP deviations die out at different rates during war and non-war years.
} 
a constant, transitory war and plague dummies, and time trend; and iii) a constant, transitory war and plague dummies, permanent war and plague dummies, and time trend. Tables $A 1$ and A2 in the second appendix report the war and plague dummy dates, as well as average coefficient estimates on each.

\subsubsection{Results}

Table 1 lays out the basic format for most of the Tables, showing the number of data points for each relative price by century. Each Table reports estimates obtained from the full sample (1273-1991), as well as century-long subperiods (1273-1399, 1400-1499, etc.). We also report estimates from the 1973-91 subperiod, which helps us examine the effects of floating exchange rates.

The variable $\ln \left(P_{i}^{U K} / P_{i}^{H o l}\right)$ is the (log) relative price of the $i$ th British good relative to the same Dutch good. This is the category of relative prices we use to examine the performance of LOP. Obviously, data coverage is less than for either of the corresponding individual-country series, since to test LOP one must have prices for both countries. The category marked $\ln \left(P_{i}^{U K} / P_{W h e a t}^{U K}\right)$ denotes the price of various goods in England relative to wheat; the category marked $\ln \left(P_{i}^{\text {Hol }} / P_{\text {Wheat }}^{\text {Hol }}\right)$ is defined analogously. Finally, the categories marked $\ln \left(P_{i}^{U K}\right)$ and $\ln \left(P_{i}^{H \circ l}\right)$ denote the prices of goods relative to silver in Britain and Holland, respectively.

The Tables also include a few simple relative price indexes. 'Traded' goods include (somewhat arbitrarily) grains and peas, and nontraded goods include butter and cheese. Naturally the tradeability of these goods changes over time; during wars tradeability of all goods declines, tradeability of butter and cheese also increases during the winter months each year as well as over the 700-year sample. We did not include eggs in these tables because of the larger number of missing observations.

Turning to the estimates, Table 2 presents a simple calculation of the average annual price change in each series (times 100), whereas Table 3 gives the average estimated trend coefficient across our full universe of specifications. Table 4 reports the average of the estimated standard errors of the trend coefficients. These standard errors are calculated using GLS, allowing for AR(1) residuals. Table 5 presents the empirical standard deviation across trend coefficients. These are intended as a measure of the robustness of our estimates to the treatment of plague and war dummies. Table 6 reports the 
estimated first-order autocorrelations from the GLS estimation.

Generally, the trends in Tables 2 and 3 are not large relative to the estimated standard errors. There are few cases where the average estimated coefficient is two or more times the estimated standard error of the trend coefficients. These results for average coefficients generally mirror the individual regression results. Ignoring the imprecision of the estimates, century-long trends tend to be large and variable. As Table 3 indicates, average trend movements of half a percent per year are not uncommon over many centurylong intervals, even for LOP deviations. For example, the point estimates in Table 3 show the relative price of English-to-Dutch barley falling until 1600, at which point it began to grow at $1.40 \%$ per year during $1600-99$, only to decline again in the following century at an average annual rate of $1.10 \%$. The former is not quite statistically significant though the estimate for the $1700 \mathrm{~s}$ is, if one goes by the standard errors reported in Table 4. Table 5 suggests specification choice (the choice of whether and how to include plague and war dummies) has a relatively minor effect on the estimated trend.

Over the entire sample, there is little evidence of any trend in crosscountry relative prices. Table 3 shows that the six commodity prices fell on average in England relative to Holland, but by an average of less than 10 basis point per year. However, in spite of having over 700 years of data (ignoring missing observations), the average time-series standard error for this point estimate is almost 11 basis points, so the long-term trend does not appear strongly significant.

The second point made by Tables $2-5$ is that century-long trends in deviations from the LOP are correlated across commodities. That is, within the $P_{i}^{U K} / P_{i}^{H o l}$ category, the trend estimates tend to cluster around similar values for each century, yet they differ considerably across centuries. To quantify this, the last line in the $P_{i}^{U K} / P_{i}^{H o l}$ group records the mean trend estimate for each century. Note that these mean trends - see Table 2 for example, seem to change sign almost every other century (positive in the 1273-1399, 1500-1599, 1700-1799, and 1973-1991 subperiods, and negative elsewhere).

In addition to the means, we report the standard deviation of the means, in order to gauge how different average trends were from zero and from each other. Several of the mean trends are different from zero, and a number are different from one another (particularly toward the end of the sample). Indeed it appears that the dispersion of trends across goods within each century is small relative to the dispersion of trends over the broader sample, suggest- 
ing that there is correlation in low frequency movements across deviations from LOP, as suggested by the graphs above.

The results for relative prices of agricultural and dairy goods within countries, given by the results for the $P_{i}^{U K} / P_{W h \text { heat }}^{U K}$ and $P_{i}^{H o l} / P_{W h \text { heat }}^{H o l}$ categories, are broadly similar. There are large changes in trends century by century, with considerable correlation across trends for various goods within the same century. The century-long trend estimates are roughly similar in magnitude to the trends in deviations from the LOP. Note, however, that the estimated full-sample trends are often much larger in absolute value than are the fullsample LOP trends. For example English and Dutch butter increased in price relative to local wheat by an annual average of 41 and 36 basis points, respectively, over the full sample, whereas the price trend in English relative to Dutch wheat was only -7 basis points. The estimates for other prices suggest similar results.

Note, finally, that Table 6 suggests that the residuals from these regressions have become more serially correlated over time. Many of the point estimates for 1273-1399 and 1500-1599 show some negative autocorrelations. These estimates are in almost every case higher during the latter centuries, particularly the 20 th.

\subsection{Volatility of Relative Prices}

In this subsection we focus on higher-frequency price movements, looking at volatility much as we did conditional trends above. Table 7 gives the simplest measure of volatility, the standard deviation of the log of British prices (in terms of silver) minus the log of Dutch prices, i.e., the standard deviation of absolute deviations from LOP. The series are extremely volatile by this measure, with standard deviations for annual movements generally in excess of thirty percent. Even more remarkably, none of the commodity price series show any obvious trend in volatility over the centuries; volatility of absolute deviations from LOP are actually lower under the post-1973 float despite the high volatility of nominal exchange rates. Table 8 reports average conditional volatility across a variety of specifications allowing for constants, trends, and both temporary and permanent plague/war dummies. While somewhat lower than the volatility estimates given in Table 7 , the standard deviations for LOP deviations in Table 8 remain quite large, generally in excess of $20 \%$ per year. (By comparison, the annual standard deviation of the S\&P 500 stock 
index since the mid-1920s has only been roughly $19 \%$ per year.) As in Table 7 , there is no obvious tendency for the volatility of LOP deviations to rise or fall over time. The volatilities in the 20 th century are roughly the same as in the fourteenth. As Table 8 demonstrates, the estimated conditional volatility is quite similar across the various specifications.

Table 8 also presents measures of volatility of within-country prices relative to wheat. Note that the volatility of within-country prices of different goods is generally of the same order of magnitude, if not larger, than the volatility of price differentials for the same good in different countries. Also, as in the case of LOP deviations, within-country relative price volatilities are generally quite stable across time.

The final point to take from Tables 7 and 8 is that deviations from LOP appear to exhibit strong common country components. The final two lines under the $P_{i}^{U K} / P_{i}^{H o l}$ category in these two tables show: a) the average pairwise off-diagonal correlations across LOP deviations, and b) the standard deviation of this average. The century-by-century correlations and covariances are all strongly positive, averaging about 0.55 and about $5 \%$, respectively. (Including the six diagonal elements, the average correlation rises to 0.55 to $\frac{.55(6-1)+1}{6}=0.625$.)

What can one learn about the implied magnitude of real exchange rate fluctuations from these numbers? Suppose for a moment that there are $N$ equally-weighted goods in the geometrically-weighted CPI in each country. Then the variance of the log real exchange rate around PPP is just the average covariance of deviations from the LOP across goods:

$$
\operatorname{Var}(R)=\frac{\sum \sum \rho_{i, j} \sigma_{i} \sigma_{j}}{N^{2}}
$$

where $\rho_{i, j} \sigma_{i} \sigma_{j} \equiv \operatorname{Cov}\left(\ln \left(P_{i}^{U K} / P_{i}^{H o l}\right), \ln \left(P_{j}^{U K} / P_{j}^{H o l}\right)\right)$.

Suppose next that the cross-country relative price of the $i$ th $\operatorname{good}, \ln \left(P_{i}^{U K} / P_{i}^{H o l}\right)$, is comprised of two orthogonal components, a country-wide shock to the relative price of pure non-traded goods and an idiosyncratic disturbance, $\ln \left(P_{i, t}^{U K} / P_{i, t}^{H o l}\right)=\alpha_{i} \ln \left(P_{n t, t}^{U K} / P_{n t, t}^{H o l}\right)+\theta_{i} \varepsilon_{i, t}$, where $\alpha_{i}$ and $\theta_{i}$ are parameters, and $\varepsilon_{i, t} \sim N(0,1) \forall i, t$; and $E\left(\varepsilon_{i, t} \varepsilon_{j, t}\right)=0, \forall t, i \neq j$. If we assume that $\alpha_{i}=1$, then the variance of the real exchange rate is equal to the variance of shocks to pure non-traded goods, $\operatorname{Var}\left(\ln \left(P_{n t, t}^{U K} / P_{n t, t}^{H o l}\right)\right)$, and can be estimated by the average cross-covariance. In our data the average cross-covariance is 
about $5 \%$, which implies an average annual real-exchange-rate volatility of $22 \%$.

Alternatively, we might assume $\alpha_{i}=\theta_{i}$, which implies that correlation (rather than the covariance) across goods is fixed. In this case, equation (1) can be rewritten as:

$$
\operatorname{Var}(R)=\left(\frac{\sum \sum \rho_{i, j}}{N^{2}}\right)\left(\frac{\sum \sum \sigma_{i} \sigma_{j}}{N^{2}}\right)=\left(\frac{\sum \sum \rho_{i, j}}{N^{2}}\right)\left(\frac{\sum \sigma_{i}}{N}\right)^{2}
$$

The rightmost expression is just the product of the average correlation (including diagonal elements) and the square of the average own-price volatility. Assuming an average volatility of $25 \%$ for deviations from the law of one price, the data suggest that the average annual variance of the real exchange rate during our sample is approximately, $0.625(0.25)^{2}=3.9 \%$, which corresponds to a volatility of approximately $20 \% .{ }^{10}$ Both of these numbers are actually greater than the real exchange rate volatility witnessed under floating exchange rates (about 10\%).

Of course, the large magnitude of real exchange rate fluctuations during the float has occupied many international economists (some of whom argue that investor irrationality is to blame). What is striking here is that, over the longer time frame, the recent variability of real exchange rates is normal, and perhaps even relatively low. Thus, the puzzle of why real exchange rates are so volatile applies to pre- 1850 prices as well as to those of the recent floating-rate period.

\subsection{Relative Price Dynamics}

Until now, we have restricted ourselves to examining very straightforward characteristics of the data, with the only complication being how to deal with plague and war dummies. Now we turn to looking at some of the dynamic properties of the data, to get some perspective on the rate of damping of LOP changes. We begin by testing whether LOP deviations are nonstationary, and then we go on to estimate simple ARMA specifications.

\footnotetext{
${ }^{10}$ This number declines to $14.8 \%$ if the number of goods becomes large, as the average correlation falls to 0.55 .
} 


\subsubsection{Estimation Issues}

Normally estimation and testing of ARMA models is a straightforward exercise. However, here things are complicated considerably by the large number of missing data points, especially for the dairy price series. To compute ARMA statistics and to test properly, we must implement a full-information estimation method, such as the Kalman filter. By working with state-space representations, we can estimate ARIMA specifications while keeping track of unobservable state variables.

The specific algorithm we use is similar to that developed by Gardner, Harvey, and Phillips (1992). ${ }^{11}$ This algorithm allows us to compute an exact likelihood function which can be maximized iteratively using numerical optimization techniques. See the technical appendix for a discussion of our approach.

While this approach is needed to obtain consistent estimates, its complexity makes it difficult and time consuming to add many parameters. As a result, in the tables below we stick with highly parsimonious representations, including constant terms, but leaving out the plague and war dummies.

\subsubsection{Tests for Unit Roots}

Table 10 presents estimates of augmented Dickey-Fuller (ADF) tests of the hypothesis that the prices contain unit roots. We report these tests for only a subset of the data, since the other series yield very similar results. The tests are performed first on our full sample of annual data. However, because we have such long series, and because we are not as interested in the highfrequency variability for these tests, we also tested applied our ADF tests a 5 -yearly data series constructed from every fifth observation. The tests are performed both with and without trend terms.

The results from Table 10 accord well with the previous findings. First, we find that deviations from the LOP appear strongly stationary. In both our 1-year and 5-year data, we reject strongly the hypothesis that the relative price of both barley and wheat contain unit roots. Butter also rejects, although more weakly. In spite of the rejections, the point estimates for the autocorrelation coefficients are generally quite high, suggesting a relatively

\footnotetext{
${ }^{11}$ On state-space procedures for estimating ARMA models with missing observations, see also Jones (1980) and Harvey and Pierce (1984).
} 
long half life for LOP deviations. ${ }^{12}$

For relative within country prices (prices of goods relative to wheat), one can also reject nonstationarity in virtually every case. For within-country prices measured in silver, this is not always true. This is particularly the case in the 5-year data, which sometimes show highly nonstationary point estimates.

\subsubsection{Chow Tests on ARMA Specifications}

In Table 11, we present the results for a simple AR(1) specification. The first column represents estimates for the full sample taken at five year intervals, whereas the second column gives the full sample estimates for the annual data. The third column gives the estimates for a dummy slope coefficient for the twentieth century, and the fourth column gives estimates for a dummy slope coefficient for the post-1973 period. T-tests of these dummy slope coefficients against zero are equivalent to Chow tests of the hypothesis that there is no change in persistence across the subsamples.

Viewing the results for the full sample, the AR coefficients $\left(\rho_{1}\right.$ in Table 11) for barley, butter and wheat are $.84, .89$ and .78 respectively. These estimates imply half lives for LOP deviations of $3.9,6.2$ and 2.8 years. These estimates are remarkably similar in magnitude to typical estimates on modern floating data for the half lives of deviations from purchasing power parity. ${ }^{13}$ Deviations from LOP, even in these relatively homogenous and highly traded commodities, is remarkably slow. The rate of convergence during the twentieth century does not appear to be significantly different from that in earlier centuries: $\rho_{2}$ is small and insignificant for all three commodities. Nor is there any evidence of change in serial correlation after the advent of modern floating exchange rates; $\rho_{3}$ is also insignificant for all three commodities. This last result accords with the results of Lothian and Taylor (1995) who use 200 years of consumer price index data and find no significant evidence that PPP deviations die out any faster or slower since the advent of floating. ${ }^{14}$

\footnotetext{
${ }^{12}$ Since the augmented Dickey-Fuller tests allow for richer dynamics than simply an $A R(1)$ specification, one cannot read the half lives directly off the AR coefficients; we will turn to discussing half lives in more detail below.

${ }^{13}$ Froot and Rogoff (1995) note that there is a remarkable consensus in the recent PPP literature on a half life for PPP deviations of roughly 3-5 years (for exchange rates across industrialized countries.)

${ }^{14}$ Our failure to reject the hypothesis of a change in persistence suggests that the in-
} 
Interestingly, the estimates of $\rho_{1}$ for prices of barley and butter relative to wheat $\left(P_{i}^{U K} / P_{W h e a t}^{U K}\right.$ and $\left.P_{i}^{H o l} / P_{W h e a t}^{H o l}\right)$ suggest that shocks to relative prices of different goods within the same country die out faster than deviations from LOP; estimates range from .46 to .74. The rates of convergence appear to have slowed during the twentieth century as the estimate for $\rho_{2}$ is positive in four cases, and significantly different from zero in three.

In addition to the AR(1) models reported above, we estimated a number of simple alternative ARMA specifications. In most instances, adding higher order autoregressive and moving average terms had little effect on the firstorder coefficients and led to only a marginal improvement in overall $R^{2} s$. Thus, we do not report other ARMA specifications here.

creased persistence documented in Table 6 is not important when comparing the entire sample with the 20 th century. 


\section{Conclusions}

It is difficult to do more than scratch the surface of potential possibilities for the data set developed here. With the exception of our Kalman filter estimates in section 3.5 , we have generally restricted our analysis to simple descriptions of the data. Nevertheless, some striking findings emerge. Most notably, we find that the magnitude and persistence of deviations from the law of one price are not dramatically different today than they were during the middle ages.

Obviously, despite our best efforts to construct the data carefully, one cannot reject the hypothesis that our results are explained by various offsetting forces. Given, however, that one would expect both greater measurement error and more impediments to trade for the early period, it is surprising that measured volatility for the middle ages is not higher. To the extent that measurement error is more important in the earlier data, and to the extent that shocks to relative prices have become more persistent since the 16 th century, then volatility has actually increased since these earlier times. In line with recent results on the modern floating-rate period, we find that deviations from the law of one price across countries are at least as large and volatile as relative prices of different goods within the same country. The law of one price deviations do not show any dramatic long-term trends, but, in keeping with the Balassa-Samuelson hypothesis, there is some evidence of shorter (century-long) trends, which appear correlated across commodities.

The data set admits a host of possibilities for further research, including allowing for richer time series dynamics, and a more complete investigation of the effects of wars and plagues. One can also expand the range of countries and commodities considered if one is willing to be content with time series that go back merely to the late seventeenth century. 


\section{Bibliography}

\section{References}

[1] Baumol, W. and W. Bowen, 1966, Performing Arts: The Economic Dilemma (The Twentieth Century Fund, New York).

[2] Cameron, Rondo, A Concise Economic History of the World, Oxford University Press, 1993, 2nd edition.

[3] Engel, C., 1993, 'Is Real Exchange Rate Variability Caused by Relative Price Changes? An Empirical Investigation,' Journal of Monetary Economics 32, 35-50.

[4] Engel, C. and J. Rogers, 1994, 'How Wide is the Border?' National Bureau of Economic Research Working Paper No. 4829.

[5] Froot, Kenneth A. and Kenneth Rogoff, 'Perspectives on PPP and LongRun Real Exchange Rates,' Harvard Business School Working Paper no. 95038, and forthcoming, Handbook of International Economics, G. Grossman and K. Rogoff, editors, Elsevier Science Publishers, B.V., North Holland Press, 1995.

[6] Gardner, G., A.C. Harvey, and G.D.A. Phillips, 'An Algorithm for Exact Maximum Likelihood Estimation of Autoregressive-Moving Average Models by Means of Kalman Filtering,' Applied Statistics, (1992), 311321.

[7] Garraty, John, and Peter Gay, editors, Columbia History of the World, Harpers Row, 1972.

[8] Giovannini, A., 1988, 'Exchange Rates and Traded Goods Prices,' Journal of International Economics 24, 45-68.

[9] Harvey, A.C., and R.G. Pierce, 'Estimating Missing Observations in Economic Time Series,' Journal of the American Statistical Association, 79, March 1984, 125-131.

[10] Isard, P., 1977, 'How Far Can We Push the Law of One Price?' American Economic Review 67, 942-948. 
[11] Jones, Richard, 'Maximum Likelihood Fitting of ARMA Models to Time Series with Missing Observations,' Technometrics, 22, August 1980, 389395.

[12] Leamer, Edward, 'Model Choice and Specification Analyses,' in Zvi Griliches and Michael Intriligator (eds.) Handbook of Econometrics, vol. I, Amsterdam: North Holland, 1983.

[13] Lothian, J. and M. Taylor, 1994, 'Real Exchange Rate Behavior: The Recent Float from the Perspective of the Past Two Centuries' (International Monetary Fund, Washington DC), forthcoming Journal of Political Economy.

[14] Palmer, R.R., and Joel Colton, A History of the Modern World, Alfred Knopf, 1978.

[15] Rogers, John, 1994, 'Real Shocks and Real Exchange Rates in Really Long-Term Data,' mimeo, Pennsylvania State University.

[16] Rogers, John, and M.A. Jenkins, 'Haircuts or Hysteresis: Sources of Movements in Real Exchange Rates,' forthcoming Journal of International Economics, 1995. 


\section{APPENDIX 1: An Annotated Bibliogra- phy of Data Sources}

\subsection{England}

\section{References}

[1] Beveridge, Sir William. Prices and Wages in England from the Twelfth to the Nineteenth Century, vol. I. London: Longmans, Green and Co., 1939. (BEV) During the 1930s, Lord Beveridge headed the International Scientific Committee on Price History, which produced two of the key references used in our study (the Beveridge book for England and the Posthumus book for Holland). The Beveridge contains data on a variety of commodity prices for Southeastern England (London and nearby vicinity), covering the early sixteenth century to the late eighteenth century. The data were largely constructed from the purchasing records of various institutions, including colleges and hospitals, and the Royal Navy ("Navy Victualling"). In addition, some prices are based on records kept by "the Lord Steward's Department" which (under the monarchy) purchased the provisions for the various Royal Palaces around London.

[2] Board of Trade. Report of Wholesale and Retail Prices, London: 1903. (BOT) The Report, published at the request of Parliament, contains commodity prices encompassing the 19 th century.

[3] The Economist. (ECO) During the 19th and early 20th century, The Economist published weekly statistics on wholesale prices of various commodities.

[4] Jastram, Roy W. Silver: The Restless Metal. New York: John Wiley \& Sons, 1981. (JAS) The book examines the development of silver in the United Kingdom and the United States. Tables at the end of the book provide a long (1273-1977) time series on the price of silver in England.

[5] Ministry of Agriculture and Fisheries. Index Numbers of Agricultural Prices. 1930. (IND) A report providing wholesale prices of agricultural products for the 1920s. 
[6] Journal of the Royal Statistical Society. (JRSS) Over the period 18951938 , the Journal annually published a table of wholesale commodity prices.

[7] Mitchell, B.R. and Deane, P. Abstract of British Historical Statistics. Cambridge: Cambridge University Press, 1962. (MITI) Both Mitchell and Dean, and Mitchell and Jones (below) contain a wide variety of time series encompassing a wide range of socio-economic issues.

[8] Mitchell, B.R. British Historical Statistics. Cambridge: Cambridge University Press, 1988. (MITII)

[9] Rogers, J.E. Thorgold. A History of Agriculture and Prices in England vol. I, IV, and V. Oxford: Clarendon Press, 1866. (ROG) Includes annual average tables, constructed by taking the average of all the prices available for a given year. Most of the disaggregated series comes from various institutions, large estates and town markets.

[10] Statistical Abstract of Great Britain. (SAGB) Statistical Office of the European Communities. Agricultural Price Statistics. (APS)

[11] Stratton, J.M. and Brown, J.H. Agricultural Records. London: John Baker Limited, 1978. (AR) This book contains price tables in the appendix, drawn largely from secondary sources, including the Rogers book (above) or various government statistics.

\subsection{Holland}

\section{References}

[1] Bieleman, Jan, Boeren Op Het Drentie Zand 1600-1910. Utrecht: Hes Vitgevers, 1987. (BIE) Contains a table of annual wheat and rye prices.

[2] Knibbe, Merijn. Agriculture in the Netherlands: 1851-1950. Amsterdam: NEHA, 1993. (KNI) Contains tables of annual wholesale agricultural prices.

[3] Jaarcijfers (Statistical Abstract of the Netherlands). (JAA) 
[4] Central Bureau of Statistics. Negentig Jaren In Tydreeksevl 1899-1988. 1989. (NEG) Commodity price tables for the 20th century, based on government sources.

[5] Posthumus, N.W. Inquiry Into the History of Prices in Holland, vol.1. Leiden: E.J. Brill, 1946. (POSH) The two Posthumus volumes, which grew out of Beveridge's International Scientific Committee on Price History, are the most important source of data for pre-nineteenth century Holland. Volume I contains wholesale prices from the Amsterdam Exchange covering the 17th through 19 th centuries. This volume also contains extensive time series on silver prices in Holland and market foreign exchange rates.

[6] Posthumus, N.W. Inquiry Into the History of Prices in Holland, vol. II. Leiden: E.J. Brill, 1964. (POSII) Volume II contains commodity prices from various institutions, such as hospitals and orphanages, in Utrecht, Leyden and Amsterdam. The methodological approach is akin to Beveridge. Overall, the data encompass from the middle 14th century to 1914 .

[7] Statistiek van Nederland. Marktprijzen van Granen te Arnhem, 1903. (SVN) A government publication giving annual prices in Arnhem for various grains from the late 16th century to 1901 .

[8] Van Der Wee, Herman. The Growth of the Antwerp Market and the European Economy Vol. I. The Hague: Martinus Nijhoff, 1963. (WEEI) Contains various price tables for commodities in various cities in Flanders and Brabant. (These areas were economically integrated with Holland from the time of the Holy Roman Empire until the late 16th century when Holland gained its independence.) The prices here are from institutional sources, mainly hospitals, cited in the Flemish silver groat; which equalled $1 / 40$ of one Dutch guilder in 1575.

[9] Van Reil, Arthur. Prices and Economic Development in the Netherlands, 1800-1913. (University of Utrecht, 1995 forthcoming). (VR) Contains annual prices on basic commodities drawn from provincial annual reports and archive records of market prices for various cities in Holland, including Amsterdam and Utrecht. 


\section{Data Coverage by Commodity/Year/Country}

Below, for each commodity, we list the years covered by each source, including some information on the underlying primary sources.

\subsection{England}

\section{Barley}

I) ROG: 1259-60, 1262-64, 1266-1504, 1506-11, 1513-42, 1545-49, 1552-53, $1555-69,1571-74,1578,1580,1583-95,1597-1649,1652-57,1662-63$, $1671,1681-82,1685-86,1696,1699,1701$.

II) BEV:

A) Lord Steward's Department:

a) Pearl Barley, 1660-62, 1665, 1669-1830.

III) MITII: Average Wholesale Price for United Kingdom, 1771-1797, 17931980.

IV) BOT: Mid-Lothian Scotland Wholesale Price, 1801-1902.

V) SAGB: Price Received by Producer, 1981-1991.

\section{Butter}

\section{I) BEV:}

A) St. Bartholomew's Hospital (Sandwich), 1573, 1575, 1577-79, 1582, $1586-88,1596-98,1601-12,1614,1616,1618-19,1621-26,1628$, $1630,1637,1644-45,1652-53,1656,1658-65,1667-68,1670-74$, $1676,1678-80,1684-1700,1704-06,1718-43,1745-48,1750-66$.

B) Lord Steward's Department, 1659-66, 1669-82, 1684-88, 1690-94, 1698-1830.

C) Navy Victualling London, 1683-84, 1686, 1688-98, 1700-23, 1725$46,1749-61,1763-1826$. 
D) Westminster School (Westminster), 1688-90, 1692-96, 1699, 170809, 1713, 1716-22, 1729-36, 1738-84.

E) Chelsea Hospital, 1702-12, 1714-95.

II) ROG: 1583-1609, 1611-24, 1626-27, 1629, 1631, 1633-51, 1653-57, 1663, 1671-79, 1681-1701.

III) BOT:

A) Royal Hospital (Greenwich), 1805-68, 1873-1902.

B) Bethlehem Royal Hospital (London) 1815-1902.

IV) JRSS: Wholesale Price, 1895-1938.

V) SAGB: Price Received by Producers, 1920-1956.

VI) APS: Price Received by Producers, 1969-1982.

\section{Cheese}

I) BEV:

A) St. Bartholomew's Hospital (Sandwich):

a) Suffolk Cheese, 1572-73, 1575, 1577-79, 1582-83, 1586-87, 1596, $1598,1602-04,1606,1612,1614,1618-21,1624-30,1633-35$, $1637-38,1641-42,1644-45,1652-53,1656,1658-65,1667-68$, $1670-74,1676,1678-80,1682,1685-1700,1704-06,1718-27$, $1734-46,1748-51$.

b) Cheshire Cheese, 1652-53, 1656-65, 1667-68, 1670-73, 1676, 1678-80, 1684, 1691-92, 1698, 1704-05, 1718-30, 1734-52, 1759, 1761-66.

B) Navy Victualling London:

a) Suffolk Cheese, 1683-84, 1686, 1688-90, 1692-98, 1700-23, 1725$40,1742-46,1748,1750-57$.

b) Cheshire Cheese, 1758-61, 1763-1826. 
C) Westminster School (Westminster), 1688-90, 1692-96, 1700-03, 1708$09,1712,1716-23,1729-36,1738-84$.

D) Chelsea Hospital, 1702-12, 1714-95.

E) Greenwich Hospital (Greenwich), 1712-1823.

II) BOT: Bethlehem Royal Hospital (London), 1815-1902.

III) ECO: Wholesale Price

A) Edam Cheese, 1903-1915.

B) Cheddar Cheese, 1915-1917.

IV) SAGB: Wholesale Price Cheddar Cheese, 1920-1944.

V) IND: Farmhouse Cheese Fairs Price, 1927-1937.

VI) APS: Cheddar Cheese Price Received by Producer, 1969-1980.

\section{Eggs}

I) ROG: 1583, 1585, 1587-1600,1602-03, 1605-09, 1611-24, 1627, 1629, $1631,1634-36,1639-45$.

II) BEV:

A) Lord Steward's Department, 1669-82, 1684-88, 1690-95, 1698-1741, 1743-1830.

B) Westminster School (Westminster), 1688-89, 1693-97, 1699-1702, 1708-09, 1716-18, 1720-23, 1728, 1730-35, 1737-77, 1780, 1783-84.

III) BOT: Retail Price in London, 1858-1872, 1886-1902.

IV) ECO: Wholesale Price, 1860-1871, 1899-1917.

V) SAGB: Price Received by Producer, 1920-1991.

VI) APS: Price Received by Producer, 1950-68, 1972-81. 
Oats

I) ROG: 1259-65, 1267-69, 1272-1504, 1506-11, 1514-16, 1518-55, 1557-68, 1570-81, 1583-1702.

II) BEV: Winchester College (Winchester), 1630-1817.

III) MITII: Average Wholesale Price for England and Wales, 1771-1980.

IV) BOT: Mid-Lothian Scotland Wholesale Price, 1801-1902.

V) SAGB: Price Received by Producer, 1981-1991.

\section{Peas}

I) ROG: 1263-68, 1270-1463, 1465-69, 1471-76, 1479-87, 1489, 1491, 1495$96,1498,1500,1505-11,1513-16,1518-19,1524-30,1532-33,1535,1541$, $1547,1554-57,1560,1563-90,1592-1678,1680-84,1687-89,1692-94$, 1696-97, 1701-02.

\section{II) BEV:}

A) Navy Victualling:

a) London, 1683-1761, 1763-90, 1792-99, 1801-03, 1805-26.

b) Portsmouth, 1683-89, 1691-95, 1698, 1700-09, 1711-23, 1722$35,1737-39,1741,1743-46,1754-55,1757-58,1767,1775-77$, 1780-82, 1786, 1789, 1795, 1804-09, 1811.

c) Plymouth, 1683-89, 1692-96, 1698-1709, 1711-13, 1715-16, 1718 $19,1721,1726,1729,1731,1734-35,1737,1739-41,1744$, $1746,1777,1780-82,1787-88,1790,1792,1797,1806,1811-12$.

B) Greenwich Hospital (Greenwich), 1712-1823.

\section{III) BOT:}

A) Market Price, $1810-1859$.

B) Retail Price (London), 1870-1902.

IV) ECO: Wholesale Price 1860-1869. 
V) SAGB: Price Received by Producer, 1927-1956.

VI) APS: Price Received by Producer, 1969-1982.

\section{Silver}

I) JAS:
A) Mint Price (Official Value) 1273-1730, 1800, 1806, 1808-10.
B) Market Price 1731-99, 1801-05, 1807, 1810-1991.

\section{Wheat}

I) ROG: 1259-1504, 1506-1702.

II) AR: 1585-88, 1594-1789.

III) MITI:
A) Exeter College, 1316-37, 1340-1464, 1466-1501, 1503-05, 1507, 1509, $1511-28,1532-57,1559-69,1571-75,1577,1581-82,1584-1601$, $1505-11,1514-15,1518,1520-1703,1705-27,1731-1820$.
B) Eton College, 1594-1641, 1644-1820.

IV) BEV:
A) Winchester College (Winchester), 1630-1817.
B) Navy Victualling:
a) London, 1683-1748, 1751-1801.
b) Portsmouth, 1743-44, 1746-61, 1763-1826.

V) MITII: Average Wholesale Price in Great Britain, 1771-1980.

VI) BOT: Mid-Lothian Scotland Wholesale Price, 1801-1902.

VII) SAGB: Price Received by Farmers, 1981-1991 . 


\subsection{Holland}

\section{Barley}

I) WEEI: Antwerp Institutional Prices, 1367-71, 1373-74, 1376, 1378, 13801580.

II) POSII:

A) St. Bartholomew's Hospital (Utrecht), 1462, 1464-65, 1466-69, 1473-76, 1482-86, 1488-1564, 1566-72, 1575-81, 1589-93.

B) St. Catherine's Hospital (Leyden), 1392, 1394, 1396-98, 1400-02, 1404-05, 1411, 1414-16, 1418-20, 1422-27, 1432, 1434-36, 1438-40, $1445,1448-50,1452-54,1456,1458-59,1461,1466-67,1470,1475$, $1477,1480-1588,1590,1593,1595-1660,1668,1709-10$.

III) POSI:

A) Winter Barley, 1609, 1624, 1626, 1628, 1630-33, 1635-38, 1640$43,1645-46,1648-54,1665,1669,1671-72,1674,1676-77,1679$, 1681-82, 1686, 1688-90, 1692, 1701, 1703, 1705-06, 1708-10, 1718, $1722,1728,1731-48,1750-58,1760-82,1784-1807,1810-12,1818-$ $21,1824-61,1863-64$.

B) Groningen and Oldmbt Winter Barley, 1681, 1690, 1692, 1701, $1703,1705,1706,1708-09,1718,1722,1728,1731-48,1750-58$, 1760-82, 1784-85, 1789, 1791-92, 1795-1807, 1810-12.

IV) JAA: Average Market Quotation Price
A) Summer Barley, 1875-99, 1901-09, 1913-36.
B) Winter Barley, 1875-1936.
C) Barley, 1945-1977.
D) Brewing Barley, 1973, 1976-85.
E) Fudder Barley, 1973, 1976-85. 


\section{Butter}

I) WEEI: Brussels, 1385-1422, 1423-77, 1479-1580.

\section{II) POSII:}

A) St. Catherine's Hospital (Leyden), 1411, 1414-27, 1432, 1434-36, $1439-41,1445,1448-50,1452-54,1456,1458-59,1461,1466-67$, $1470,1475,1477,1480-94,1501-02,1504-09,1512-29,1531-70$, $1572-74,1583,1585-87,1589,1591-1677,1680,1684,1690-1731$, 1733.

B) St. Bartholomew's Hospital (Utrecht), 1464-68, 1470-77, 1482-84, $1486,1488-1564,1566-83,1585-1604,1606-08,1610-19,1621-27$, $1630,1632-51,1653-85,1687-1770,1772-96,1798-1801,1803-08$, 1810-1914.

C) Municipal Orphanage (Amsterdam), 1585-88, 1596, 1612-13, 1620, $1628,1634,1637,1639,1641-42,1644,1646-57,1659-60,1662-$ $68,1670,1672-80,1682-96,1698,1701,1706,1713-15,1717-21$, $1726-28,1749,1779,1782-1795$.

III) POSI: Frisian Butter, 1816-24, 1829-35, 1841-43.

IV) KNI: 1851-1950.

V) JAA:

A) Merengberg Insane Asylum, 1857-1929.

B) Average Market Price, 1875-83.

C) Auction Price, 1887-1930.

D) Average Market Price (Delft), 1875-1900.

E) Average Market Price (Leeuwarden), 1875-1900, 1903-17, 1920-39.

F) Average Market Price (Maastricht), 1901-39.

VI) NEG: Consumer Prices, 1935-1988. Converted to wholesale price by dividing by 1.19. This number was the average ratio of this price to the price listed in (VII).

VII) APS: Price Received by Producer 1969-1982. 


\section{Cheese}

I) WEEI: Antwerp Price at St. Bavo's Fair
A) Flemish Cheese, 1385-1560.
B) Dutch Cheese, 1522-1551.

\section{II) POSII:}

A) St. Bartholomew's Hospital (Utrecht), 1532-44, 1546-78, 1575$83,1585-1608,1612-15,1617-19,1621,1623-24,1629-37,1640-$ $41,1649,1651-95,1697-1770,1772-73,1775,1778-1810,1812-13$, 1815-1914.

B) Municipal Orphanage (Amsterdam)

a) Cheese, $1566,1586,1594,1621-31,1637-40,1642-47,1649-50$, $1652-57,1659,1661-63,1665,1667,1670-1704,1706-08,1711-$ $15,1717-20,1722,1724,1728,1731-38,1741$.

b) Leyden Cheese, 1563, 1591-1613, 1615-17, 1620, 1631, 1635, $1637,1640,1643,1645-51,1653,1655-56,1658-59,1661-72$, $1674,1676,1680,1682,1785-91,1794$.

c) Edam Cheese, $1649,1666,1671-72,1676-78,1680-82,1684-$ $87,1689,1691-93,1697-99,1702,1704-09,1711-12,1716-17$, $1762,1784-1800$.

C) St. Catherine's Hospital (Leyden), 1575-86, 1588-93, 1595-97, 1599, $1601,1603-12,1615-16,1618-20,1651-53,1655-66,1669-73,1677$, $1685-88,1690-1700,1702-04,1715,1719-22,1727-35,1737,1738$, $1743,1746-47,1749-50,1755-60,1763-64,1767-93$.

D) Holy Ghost Hospital and Children's Home (Leyden), 1621-74, 1676$77,1679,1683-88,1694,1710-25,1728-70,1773-88,1790-92,1794$, $1795,1797$.

III) KNI: Market Quotation, 1851-1950.

IV) JAA:

A) Average Market Price 

a) Friesche Cheese, 1875-1900.
b) Edammer Cheese, 1875-1900.
c) Goudsche Cheese, 1875-96, 1898-1900.

B) Average Market Price
a) Bodegraven, 1911-17, 1919-39.
b) Utrecht, 1911-16.
c) Purmerend, 1911-39.
d) Delft, 1911-16.
e) Leyden, 1911-39.

C) Price Received by Producer, 1978-1987.

V) NEG: Consumer Prices Belegen Goudse Cheese, 1935-1988. Price converted to wholesale price by dividing by 1.77 . This number was the average ratio of this series to (VII).

VI) APS: Price Received by Producer Goudse Cheese, 1969-1989.

\section{Eggs}

I) WEEI: Brussels, 1390-1406, 1408-22, 1455, 1459-60, 1462, 1464, 1470-99, $1505-13,1516,1522,1526-1600$.

\section{II) POSII:}

A) Holy Ghost Hospital and Children's Home (Leyden), 1621-23, 1636$46,1650-56,1664-65,1667,1669,1672-74,1680-82,1685-86,1688-$ 90, 1721-24, 1726-30, 1734, 1736, 1738-39, 1743-47, 1751, 1753-54, $1756,1760,1762-66,1773-76,1778-83,1785-94,1796-98$.

B) Municipal Orphanage (Amsterdam), 1636, 1639-41, 1643-46, 1648$52,1663$.

III) KNI: Market Quotations 1851-1950.

\section{IV) JAA:}

A) Average Market Price 

a) Assen, 1901-02, 1905-09.
b) Rotterdam, 1901-1910.
c) Maastricht, 1901-15, 1917, 1919-20.
d) Zutphen, 1911-20.
e) Roermond, 1911-39.
f) Eschede, 1920-39.
g) Arnhem, 1920-30.
h) Oostberg, 1920-39.

B) Price Received by Producer, 1955-87.

V) NEG: Price Received by Producer, 1949-80.

VI) VR:
A) Drenthe, 1813-1908.
B) Overijssel, 1856-1913.

\section{Oats}

I) WEEI: Antwerp, 1366-92, 1394-1423, 1425-1580.

\section{II) POSII:}

A) Chapter of Oldminster (Utrecht)

a) Price on St. Martin's Day, 1371-73, 1376-98, 1401-11, 1372-74, 1377-99, 1402, 1404-12, 1427, 1429-31, 1434, 1436, 1439, 1441, $1461-63,1465-66,1469-70,1472,1474,1476,1478,1481-83$, 1485-91, 1494-96.

b) Price on St. Peter's Day, 1372-74, 1376-98, 1401-11, remaining dates same as on St. Martin's Day (a).

B) Cathedral Chapter (Utrecht), 1394, 1401-21, 1423-25, 1427-33, 1435$48,1450-55,1457,1459-1618,1620-50,1653-55,1659-60,1665$.

C) St. Catherine's Hospital (Leyden), 1394, 1396-98, 1401-02, 140506, 1414-24, 1426-27, 1432, 1434-36, 1439-41, 1445, 1448-50, 1452$59,1456,1458-59,1461,1466-67,1470,1475,1477,1480-1563$, 1566-67, 1570-91, 1594, 1597-1602, 1604, 1606, 1615, 1623-24. 
D) St. Bartholomew's Hospital (Utrecht), 1462, 1464, 1466-68, 1471$73,1476-77,1482-83,1485-88,1490-92,1495-1506,1508-14,1516$ $64,1566-72,1576,1579,1581-83,1586,1588$.

\section{III) POSI:}

A) Brew Oats, 1669, 1671-72, 1674-77, 1679, 1683, 1685-89, 1691, $1694,1701,1703,1705-06,1708-10,1718-19,1722,1728,1731-48$, $1750-58,1760-82,1784-1808,1810-12$.

B) Forage Oats, same years as Brew Oats plus 1816-85, 1828-56.

\section{IV) JAA:}

A) Average Market Price, 1875-1939.

B) Price Received by Farmers, 1947-1987.

\section{Peas}

I) WEEI: Malines, 1367-69, 1373-76, 1381-82, 1385, 1400, 1405-08, 1419, 1421-22, 1427-92, 1494-1504, 1506-70, 1572-1580.

\section{II) POSII:}

A) St. Catherine's Hospital (Leyden):

a) Green Peas, 1392, 1401-03, 1419, 1424, 1448-50, 1452-54, 1456 $58,1466-67,1470,1480,1518-29,1575,1584,1599,1601$ 02, 1608-09, 1611, 1615-16, 1618, 1620-21, 1623-24, 1626-34, 1636-37, 1639-46, 1648-56, 1658-62, 1664, 1671-72, 1674-75, 1680-81, 1684, 1689, 1697-99, 1705, 1709.

B) St. Bartholomew's Hospital (Utrecht):

a) Green Peas, 1524-30, 1532-37, 1539-61, 1563-65, 1567-68, 1571$72,1574-75,1577,1579,1582,1585-91,1594-1604,1610-16$, $1618,1621,1623-25,1627-35,1671-74,1676,1684-86,1688$ $92,1695-96,1698,1702-03,1705,1707-11,1713,1717-24$, $1726,1728,1730-31,1733-36,1741,1743-44,1746-74,1778-$ 84, 1786-87, 1789-1801, 1803-09, 1811-21, 1823-41, 1843-49, $1852,1854-59,1862-1914$. 
C) Holy Ghost Hospital and Children's Home (Leyden):

a) Green Peas, 1604-20, 1622-25, 1627-28, 1630-31, 1633, 1637-39, 1641-42, 1644, 1646-47, 1649-51, 1653-54, 1657-58, 1660-63, $1666-68,1669,1721,1723-26,1728,1731-33,1749-53,1755-$ $56,1758,1760-71,1773-74,1779-82,1784,1786-90,1792-95$, 1797-1800.

D) Municipal Orphanage (Amsterdam)

a) Green Peas, 1562, 1565, 1569, 1585, 1588-91, 1597, 1599, 1602, $1625,1632-34,1638-39,1645,1648-50,1652,1654-56,1658-$ $59,1661,1695-99,1701,1703,1705,1707,1709-12,1714-16$, $1719,1721,1723$.

III) JAA:
A) Average Market Price, 1875-1939.
B) Merengberg Insane Asylum, 1857-1910.
C) Price for Various Institutions, 1881-1930.
D) Prices Received by Producers, 1947-1987.

Silver [Dutch prices are quoted in fine silver, and were converted to standard silver prices (to correspond to British series) by multiplying prices by .925 . This conversion ratio is taken from JAS.]

I) WEEI: Silver content of Flemish Groat (40 Groats $=1$ Guilder), 13651574 .

\section{II) POSI:}

A) Silver Content of Guilder, 1575-1730.

B) Marker (Market) Price of Silver, 1730-1914.

III) JAS: 1915-1991. Series constructed by assuming law of one price for silver, and using Guilder-Pound Sterling Exchange Rate to convert British pound price to guilders. (JAA) 


\section{Wheat}

\section{I) POSII:}

A) Cathedral Chapter (Utrecht):

a) $1394-96,1400-01,1403-12,1414-20,1422-25,1427-31,1435-36$, $1438,1440-48,1450,1460-1513,1515-1655,1659-60$.

b) First Marketday in September, 1501-04, 1507-08, 1535-1625, 1628.

B) St. Catherine's Hospital (Leyden), 1394, 1396-98, 1401-03, 1405$06,1411,1414-27,1432,1434-36,1439-41,1445,1448-50,1452-54$, $1459,1458-59,1461,1467,1470,1475,1477,1480-1539,1545-60$, $1562-77,1579-1615,1617-21,1623-66,1668,1670,1672-77,1680$, $1682,1686-88,1691-92,1694,1696-97,1701-11,1714-21,1723-24$, $1726,1740-41,1767-87,1789-90,1792$.

C) Market Prices in Utrecht:

a) Red Wheat, 1402-12, 1414-17, 1760-1814.

b) White and New Wheat, 1787-1851.

D) St. Bartholomew's Hospital (Utrecht), 1462-69, 1471-77, 1482$1572,1575-83,1585-1604,1606,1608,1610-16,1618-19,1621$ $27,1630,1632-38,1640-41,1649,1664-65,1668-1770,1772-1801$, 1804-1819, 1821.

E) Municipal Orphanage (Amsterdam), 1562, 1565, 1567, 1569, 1587$1632,1634,1636,1638-39,1647-68,1670-71,1673-89,1691-92$, $1694-97,1699-1702,1704-11,1713-23,1726-32,1735-40,1742-43$, $1745,1747-53,1755,1757-96,1798-1800$.

F) Holy Ghost Hospital and Children's Home Zealand Wheat (Leyden), 1604-10, 1612-13, 1615, 1618, 1620, 1623-24, 1629, 1631-65, 1668-71, 1685, 1688-89, 1724-25, 1730, 1732-33, 1735-36, 1738-40, $1742-43,1746-60,1762-71,1773-77,1779-86,1788-89,1791-1800$.

II) WEEI: Lier, 1427-69, 1479-95, 1497-1580.

III) POSI: 
A) Konigsberg Wheat, $1628,1630,1633-34,1638,1640-43,1645-46$, $1648-50,1653-54,1669,1671,1674-75,1679,1681-83,1686,1688-$ $92,1694,1701,1703,1705-06,1708-10,1713,1718-19,1722,1728$, $1731-45,1747-48,1750-58,1760-1808,1818-21,1824,1828-54$, 1858.

B) Polish Wheat, 1671-72, 1674-77, 1679, 1681-83, 1689, 1688-92, $1694,1701,1703,1705-06,1708-10,1718-19,1722,1728,1731-58$, 1760-1808, 1818-21, 1824-26, 1828-75, 1879-80.

C) Warder Wheat, 1648-54, 1669, 1671-72, 1679, 1681-83, 1686, 1688$92,1694,1701,1703,1705-06,1708-10,1718-19,1722,1728,1731$ $45,1747-58,1760-1791$.

D) Frisian Wheat, 1722, 1728, 1731-42, 1748, 1750-58, 1760, 1762-63, 1765-81, 1784-86, 1788-95, 1797-1808, 1810-12, 1818-21, 1824-25, 1828-1867.

E) Zealand Wheat, $1732-58,1760-82,1784-1808,1810-12,1816-24$, 1828-57, 1860, 1872.

F) For Future Delivery (3-month), 1873-1900.

IV) JAA:

A) Average Market Price, 1875-1931, 1933-39.

B) Middenprijzen, 1875-1886, 1888-1896.

V) NEG: Price Received by Producers, 1946-1988. 


\section{APPENDIX 2: Plague and War Dummies}

See Tables A1 and A2 for definitions and estimates of plague and war dummies.

\section{APPENDIX 3: Time-Series Methodology}

We wish to accomplish two objectives using time series methods: to test for stationarity, and to estimate ARMA specifications for relative prices. Because of the presence of missing observations, straightforward application of standard tests using linear estimation techniques is precluded. To handle missing observations properly in this context, it is necessary to employ a full-information method of estimation, one which involves simultaneously estimating missing observations and computing parameters. We employ the Kalman filter as a way of doing this.

Consider first the Dickey-Fuller specification. We wish to test the null hypothesis that the data are generated by a unit root autoregression with drift, using the augmented Dickey-Fuller regression

$$
y_{t}=\zeta_{1} \Delta y_{t-1}+\zeta_{2} \Delta y_{t-2}+\rho y_{t-1}+\delta_{0}+\delta_{1} t+\varepsilon_{t}
$$

Under the null hypothesis, $\rho=1$. With no missing observations, the $t$ statistic from OLS estimation of equation (3) can be compared directly to the critical values tabulated in Fuller (1976). ${ }^{15}$

Let $\left\{\alpha_{t}\right\}_{t=1}^{T}$ be the full series of observed data-if we had no missings then $\left\{\alpha_{t}\right\}_{t=1}^{T} \equiv\left\{y_{t}\right\}_{t=1}^{T}$. Whenever we observe $y_{t}, \alpha_{t}$ is observed with certainty. However, whenever $y_{t}$ is not observed, then an estimate of $\alpha_{t}$ can be obtained using the Kalman filter.

Replacing $y_{t}$ in equation (3) with $\alpha_{t}$ and rearranging, we have

$$
\alpha_{t}-\mu=\zeta_{1} \Delta \alpha_{t-1}+\zeta_{2} \Delta \alpha_{t-2}+\rho\left(\alpha_{t-1}-\mu\right)+\delta_{1} t+\varepsilon_{t},
$$

where $\mu=\frac{\delta_{0}}{1-\rho}$. Under the hypothesis that $\rho=1,\left(\alpha_{t}-\mu\right)$ is a zero-drift unit root autoregression. Equation (4) can be cast in the following state space form:

\footnotetext{
${ }^{15}$ Clearly, equation (3) can be used to estimate a simple AR(1) specification by setting $\zeta_{1}, \zeta_{2}$, and $\delta_{1}$ to be zero. In what follows, we present our Kalman filter methodology for equation (3); the results for the AR(1) estimation can be seen easily as a special case.
} 


\section{State Equation}

$$
\xi_{t+1}=\mathbf{F} \xi_{t}+\mathbf{v}_{t+1}
$$

Observation Equation

$$
\mathbf{y}_{t}=\mathbf{A}^{\prime} \mathbf{x}_{t}+\mathbf{H}^{\prime} \xi_{t}
$$

where

$$
\begin{gathered}
\xi_{t}=\left[\begin{array}{c}
\alpha_{t}-\mu \\
\Delta \alpha_{t} \\
\Delta \alpha_{t-1}
\end{array}\right] \\
\mathbf{F}_{t}=\left[\begin{array}{ccc}
\rho & \zeta_{1} & \zeta_{2} \\
\rho-1 & \zeta_{1} & \zeta_{2} \\
0 & 1 & 0
\end{array}\right] \\
\mathbf{v}_{t}=\left[\begin{array}{c}
\varepsilon_{t} \\
0 \\
0
\end{array}\right] \\
\mathbf{A}^{\prime}=\left[\begin{array}{ll}
\mu & \delta_{1}
\end{array}\right] \\
\mathbf{x}_{t}=\left[\begin{array}{l}
1 \\
t
\end{array}\right] \\
\mathbf{H}^{\prime}=\left[\begin{array}{lll}
1 & 0 & 0
\end{array}\right]
\end{gathered}
$$

and where $\varepsilon_{t}$ is assumed to be Gaussian white noise, with $E\left(\varepsilon_{t} \varepsilon_{t}\right)=\sigma^{2}$.

Under the null hypothesis, the process for the state vector is nonstationary. The Kalman filter is therefore initialized with a diffuse prior. Accordingly, $\hat{\xi}_{1 \mid 0}$, the conditional forecast of the state vector in period 1 conditional on no observations of $y$, is chosen to be

$$
\hat{\xi}_{1 \mid 0}=\left[\begin{array}{l}
0 \\
0 \\
0
\end{array}\right],
$$

while $\mathbf{P}_{1 \mid 0}$, the mean squared error associated with $\hat{\xi}$, is chosen to be

$$
\mathbf{P}_{1 \mid 0}=\lambda\left[\begin{array}{lll}
1 & 0 & 0 \\
0 & 1 & 0 \\
0 & 0 & 1
\end{array}\right],
$$


where $\lambda$ is some large number. These starting values are then updated on the basis of observations on $y$ using the formula for updating a linear projection, yielding

$$
\hat{\xi}_{t \mid t}=\hat{\xi}_{t \mid t-1}+\mathbf{P}_{t \mid t-1} \mathbf{H}\left(\mathbf{H}^{\prime} \mathbf{P}_{t \mid t-1}^{-1} \mathbf{H}\right)\left(y_{t}-\mathbf{A}^{\prime} \mathbf{x}_{t}-\mathbf{H}^{\prime} \hat{\xi}_{t \mid t-1}\right)
$$

and

$$
\mathbf{P}_{t \mid t}=\mathbf{P}_{t \mid t-1}-\mathbf{P}_{t \mid t-1} \mathbf{H}\left(\mathbf{H}^{\prime} \mathbf{P}_{t \mid t-1} \mathbf{H}\right)^{-1} \mathbf{H}^{\prime} \mathbf{P}_{t \mid t-1} .
$$

The state equation is then used to predict the first and second moments of the state in period $t+1$, conditional on all observations up to and including $t$ :

$$
\begin{gathered}
\hat{\xi}_{t+1 \mid t}=\mathbf{F} \hat{\xi}_{t \mid t} \\
\mathbf{P}_{t+1 \mid t}=\mathbf{F P}_{t \mid t} \mathbf{F}^{\prime}+\mathbf{Q}
\end{gathered}
$$

where

$$
Q=\left[\begin{array}{ccc}
\sigma^{2} & 0 & 0 \\
0 & 0 & 0 \\
0 & 0 & 0
\end{array}\right]
$$

On the assumption that both $\varepsilon_{t}$ and the initial state are Gaussian, the forecast of $\hat{\xi}_{t+1 \mid t}$ and hence $\hat{y}_{t+1 \mid t}$ are optimal among any functions of past observations of $y$. In particular, we have

$$
y_{t} \mid \mathbf{x}_{t}, y_{1}, \ldots, y_{t-1} \sim N\left(\left(\mathbf{A}^{\prime} \mathbf{x}_{t}+\mathbf{H}^{\prime} \hat{\xi}_{t \mid t-1}\right),\left(\mathbf{H}^{\prime} \mathbf{P}_{t \mid t-1} \mathbf{H}\right)\right) .
$$

Comparing each forecast with the observed value of $y_{t+1}$ generates a series of prediction errors and associated mean squared errors which can be used to construct the likelihood function from the prediction error decomposition. If $y_{t}$ is not observed in a given period, we omit the prediction error for that period from the likelihood function. The updating equations are skipped for this observation, but the prediction equations are still used to generate an optimal forecast and associated mean squared error for the subsequent period. 
Table 1: English and Dutch commodity prices 1273-1991: Number of years of data available in each period

\begin{tabular}{|c|c|c|c|c|c|c|c|c|c|c|}
\hline Category & Index & $1273-1991$ & $1273-1399$ & $1400-1499$ & $1500-1599$ & $1600-1699$ & $1700-1799$ & $1800-1899$ & $1900-1991$ & $1973-1901$ \\
\hline \multirow{8}{*}{$\ln \left(P_{i} U K / P_{i}{ }^{H o l}\right)$} & Barley & 520 & 29 & 100 & 85 & 72 & 76 & 80 & 78 & 13 \\
\hline & Butter & 386 & . & . & 22 & 99 & 100 & 98 & 67 & 10 \\
\hline & Cheese & 330 & . & . & 11 & 68 & 100 & 98 & 53 & 10 \\
\hline & Oats & 531 & 34 & 100 & 93 & 70 & 77 & 76 & 81 & 15 \\
\hline & Peas & 455 & 11 & 74 & 62 & 89 & 86 & $\mathbf{9 3}$ & 40 & 10 \\
\hline & Wheal & 583 & 5 & 99 & 99 & 100 & 98 & 100 & 82 & 16 \\
\hline & Traded & 352 & . & 74 & 50 & 61 & 66 & 65 & 36 & 10 \\
\hline & Nontrad. & 164 & . & . & 4 & 15 & 51 & 41 & 53 & 10 \\
\hline \multirow{6}{*}{$\ln \left(P_{i}^{U K} / P_{W h \text { eat }}^{U K}\right)$} & Barley & 696 & 127 & 100 & 85 & 92 & 100 & 100 & 92 & 19 \\
\hline & Butter & 392 & . & . & 22 & 99 & 100 & 100 & 71 & 10 \\
\hline & Cheese & 336 & . & . & 11 & 68 & 100 & 100 & 57 & 10 \\
\hline & Oats & 711 & 127 & 100 & 92 & 100 & 100 & 100 & 92 & 19 \\
\hline & Peas & 629 & 127 & 89 & 67 & 99 & 100 & 100 & 47 & 10 \\
\hline & Silver & 718 & 127 & 100 & 99 & 100 & 100 & 100 & 92 & 19 \\
\hline \multirow{6}{*}{$\ln \left(P_{i} H_{0 l} / P\right.$ Wheat $)$} & Barley & 512 & 5 & 99 & 99 & 77 & 76 & 80 & 76 & 13 \\
\hline & Butter & 580 & 5 & 98 & 99 & 100 & 98 & 98 & 82 & 16 \\
\hline & Cheese & 580 & 5 & 99 & 98 & 100 & 98 & 98 & 82 & 16 \\
\hline & Oats & 507 & 5 & 89 & 100 & 70 & 77 & 76 & 80 & 15 \\
\hline & Peas & 524 & . & 84 & 94 & 89 & 84 & 93 & 80 & 15 \\
\hline & Silver & 584 & 5 & 99 & 100 & 100 & 98 & 100 & 82 & 16 \\
\hline \multirow[t]{6}{*}{$\ln \left(P_{i}^{U K}\right)$} & Barley & 697 & 127 & 100 & 86 & 92 & 100 & 100 & 92 & 19 \\
\hline & Butter & 393 & . & . & 23 & 99 & 100 & 100 & 71 & 10 \\
\hline & Cheese & 337 & . & . & 12 & 68 & 100 & 100 & 57 & 10 \\
\hline & Oats & 712 & 127 & 100 & 93 & 100 & 100 & 100 & 92 & 19 \\
\hline & Pens & 630 & 127 & 89 & 68 & 99 & 100 & 100 & 47 & 10 \\
\hline & Wheat & 718 & 127 & 100 & 99 & 100 & 100 & 100 & 92 & 19 \\
\hline \multirow[t]{6}{*}{$\ln \left(P_{i} H o l\right)$} & Barley & 539 & 29 & 100 & 99 & 77 & 76 & 80 & 78 & 13 \\
\hline & Butter & 596 & 15 & 99 & 99 & 100 & 100 & 98 & 85 & 16 \\
\hline & Cheese & 596 & 15 & 100 & 98 & 100 & 100 & 98 & 85 & 16 \\
\hline & Oats & 538 & 34 & 100 & 100 & 70 & 77 & 76 & 81 & 15 \\
\hline & Peas & 538 & 11 & 84 & 94 & 89 & 86 & 93 & 81 & 15 \\
\hline & Wheat & 584 & 5 & 99 & 100 & 100 & 98 & 100 & 82 & 16 \\
\hline
\end{tabular}


Table 2: English and Dutch commodity prices 1273-1991: Average yearly relative price change in series times 100

\begin{tabular}{|c|c|c|c|c|c|c|c|c|c|c|}
\hline Category & Index & $1273-1991$ & $1273-1399$ & $1400-1499$ & $1500-1599$ & $1600-1699$ & $1700-1799$ & $1800-1899$ & $1900-1991$ & $1973-1991$ \\
\hline \multirow{10}{*}{$\ln \left(P_{i} U K^{\prime} / P_{i}{ }^{H o l}\right)$} & Barley & 0.04 & 1.26 & -0.35 & 0.14 & 0.60 & -0.48 & -0.30 & -0.29 & 2.26 \\
\hline & Butter & 0.02 & 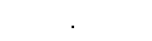 & . & 0.52 & 0.20 & 0.12 & -0.44 & 0.20 & 9.58 \\
\hline & Cheese & -0.10 & & . & 3.92 & -1.48 & 0.18 & -0.28 & 0.21 & 6.08 \\
\hline & Oats & -0.02 & 0.12 & 0.10 & -0.06 & -0.20 & -0.31 & -0.30 & -0.50 & 0.62 \\
\hline & Peas & 0.19 & 0.05 & -0.46 & -0.75 & -0.34 & 1.05 & -0.38 & 0.37 & 6.74 \\
\hline & Wheat & 0.05 & 2.09 & -0.15 & -0.82 & -0.05 & 0.85 & -0.56 & -0.06 & 0.08 \\
\hline & Mean' & {$[(0.64)]$} & $(0.88)$ & $(-0.25)$ & $(0.35)$ & $(-0.15)$ & $(0.27)$ & $(-0.38)$ & $(-0.00)$ & $(4.24)$ \\
\hline & S.D.• & {$[(0.29)]$} & $(0.57)$ & $(0.11)^{\prime}$ & $(0.67)$ & $(0.27)^{\prime}$ & $(0.23)$ & $(0.04)$ & $(0.12)$ & $(1.42)$ \\
\hline & Traded & -0.01 & . & -0.40 & -0.51 & 0.23 & 0.51 & -0.41 & 0.05 & 4.29 \\
\hline & Nontrad. & 0.10 & . & & 3.33 & 0.80 & 1.12 & -1.34 & -0.03 & 4.35 \\
\hline \multirow{8}{*}{$\ln \left(P_{i} U K / P \underset{\text { Wheal }}{U K}\right)$} & Barley & 0.00 & -0.28 & -0.35 & 0.36 & 0.03 & -1.19 & 0.85 & -0.23 & 0.11 \\
\hline & Butter & 0.25 & . & . & -0.31 & 0.19 & -0.48 & 1.39 & 0.19 & 8.40 \\
\hline & Cheese & 0.15 & . & & 0.45 & -1.46 & -0.22 & 1.47 & 0.85 & 6.65 \\
\hline & Oats & 0.04 & -0.22 & 0.04 & 0.30 & -0.17 & -0.26 & 0.82 & -0.23 & 0.84 \\
\hline & Peas & 0.13 & -0.38 & 0.24 & 0.08 & 0.25 & 0.08 & 0.91 & 0.14 & -1.00 \\
\hline & Mean" & {$[(0.50)]$} & $(-0.29)$ & $(-0.02)$ & $(0.18)$ & $(-0.23)$ & $(-0.41)$ & $(1.09)$ & $(0.14)$ & $(3.00)$ \\
\hline & S.D.* & {$[(0.31)]$} & $(0.06)$ & $(0.21)$ & $(0.15)$ & $(0.35)$ & $(0.24)$ & $(0.16)$ & $(0.22)$ & (2.11) \\
\hline & Silver & -0.20 & -0.01 & 0.66 & -0.89 & -0.29 & -1.09 & 0.80 & -0.11 & -0.27 \\
\hline \multirow{8}{*}{$\ln \left(P_{i} H o l / P P_{W h \text { eat }}^{H o l}\right)$} & Barley & 0.04 & -4.17 & -0.15 & -0.60 & 0.16 & 0.25 & 0.59 & 0.15 & -0.86 \\
\hline & Butter & 0.13 & -3.43 & -0.27 & -0.68 & -0.06 & 0.24 & 1.27 & 0.23 & 1.18 \\
\hline & Cheese & 0.28 & -11.75 & -0.15 & -0.48 & 0.15 & 0.45 & 1.19 & 1.09 & 3.72 \\
\hline & Oats & 0.08 & -7.58 & -0.21 & -0.46 & 0.22 & 0.68 & 0.56 & 0.29 & 1.08 \\
\hline & Peas & 0.11 & & -0.23 & 0.01 & 0.54 & -0.35 & 0.73 & -0.07 & -3.58 \\
\hline & Mean" & {$[(-0.52)]$} & $(-6.73)$ & $(-0.20)$ & $(-0.44)$ & $(0.20)$ & $(0.25)$ & $(0.87)$ & $(0.34)$ & $(0.31)$ \\
\hline & S.D.* & {$[(0.42)]$} & $(2.20)$ & $(0.03)$ & $(0.13)$ & $(0.11)$ & $(0.19)$ & $(0.17)$ & $(0.22)$ & $(1.36)$ \\
\hline & Silver & -0.19 & -6.10 & 0.50 & -1.71 & -0.34 & -0.24 & 0.23 & 0.48 & 3.60 \\
\hline \multirow[t]{2}{*}{$\ln \left(P_{i} U K^{i}\right)$} & Mean* & {$[(0.07)]$} & $(-0.21)$ & $(-0.66)$ & $(1.37)$ & $(0.12)$ & $(0.74)$ & $(0.11)$ & $(-0.20)$ & $(-1.05)$ \\
\hline & S.D.* & {$[(0.23)]$} & $(0.09)$ & $(0.15)$ & $(0.49)$ & $(0.26)$ & $(0.21)$ & $(0.24)$ & $(0.14)$ & $(1.63)$ \\
\hline \multirow{2}{*}{$\ln \left(P_{i}^{H o l}\right)$} & Mean ${ }^{*}$ & {$[(-0.36)]$} & $(-0.41)$ & $(-0.67)$ & $(1.34)$ & $(0.27)$ & $(0.58)$ & $(0.49)$ & $(-0.28)$ & $(-4.14)$ \\
\hline & S.D. & {$[(0.32)]$} & $(1.53)$ & $(0.04)$ & $(0.13)$ & $(0.19)$ & $(0.17)$ & $(0.21)$ & $(0.21)$ & $(1.42)$ \\
\hline
\end{tabular}

Average yearly change in series, $\left(P_{T}-P_{0}\right) / T$, times 100

- Single-bracketed figures in the rows labelled "Mean" and "S.D." give the sample mean and accompanying standard error of trend estimates for relative prices in that category and century (i.e. barley, butter, cheese, oats, peas and wheat in the category $\ln \left(P_{i} U K / P_{i} H o l\right)$. The double-bracketed figures given for Mean and S.D. in the column labeled 1273-1991 represent the mean and associated standard error of trend estimates across all seven century long periods and commodities in a given category. 
Table 3: English and Dutch commodity prices 1273-1991: Average trend times 100

\begin{tabular}{|c|c|c|c|c|c|c|c|c|c|}
\hline Category & Index & $1273-1991$ & $1273-1399$ & $1400-1499$ & $1500-1599$ & $1600-1699$ & $1700-1799$ & $1800-1899$ & $1900-1991$ \\
\hline \multirow{10}{*}{$\ln \left(H_{i}^{U K} / P_{i}{ }^{H o l}\right)$} & Barley & -0.11 & -1.44 & -0.32 & -0.25 & 1.40 & -1.10 & -0.17 & -0.67 \\
\hline & Butter & -0.17 & . & . & 1.15 & 0.26 & 0.30 & -0.83 & -0.67 \\
\hline & Clieese & -0.21 & . & . & 3.79 & -0.93 & 0.22 & -0.54 & -0.69 \\
\hline & Oats & -0.07 & -1.11 & -0.70 & 0.49 & 0.30 & -0.26 & -0.39 & -0.21 \\
\hline & Peas & 0.14 & -3.16 & 0.37 & -1.48 & 0.67 & 0.18 & 0.23 & -0.68 \\
\hline & Wheat & -0.07 & -8.98 & -0.33 & -1.21 & 0.29 & -0.01 & -0.50 & 0.14 \\
\hline & Mean* & {$[(0.12)]$} & $(-3.67)$ & $(-0.23)$ & $(0.19)$ & $(0.46)$ & $(-0.13)$ & $(-0.34)$ & $(-0.54)$ \\
\hline & S.D.* & {$[(0.34)]$} & $(2.11)$ & $(0.19)$ & $(0.76)$ & $(0.31)$ & $(0.20)$ & $(0.14)$ & $(0.15)$ \\
\hline & Traded & -0.01 & . & -0.19 & -1.16 & 1.13 & -0.22 & -0.18 & -0.97 \\
\hline & Nontrad. & -0.52 & . & . & 1.21 & 1.97 & 0.42 & -2.00 & -0.73 \\
\hline \multirow{8}{*}{$\ln \left(P_{i} U K / P \underset{W h e a l}{U K}\right)$} & Barley & 0.08 & -0.13 & 0.11 & 0.79 & 0.64 & -0.85 & 0.72 & -0.44 \\
\hline & Butter & 0.41 & . & . & -2.21 & 0.13 & -0.07 & 1.02 & -0.07 \\
\hline & Cheese & 0.45 & . & . & -2.16 & -0.96 & 0.10 & 0.86 & 0.44 \\
\hline & Oats & 0.15 & -0.04 & -0.08 & 1.27 & 0.14 & -0.14 & 0.72 & -0.18 \\
\hline & Peas & 0.28 & -0.20 & 0.39 & -0.26 & 0.66 & 0.02 & 1.28 & -0.65 \\
\hline & Mean ${ }^{*}$ & {$[(0.31)]$} & $(-0.12)$ & $(0.14)$ & $(-0.51)$ & $(0.12)$ & $(-0.19)$ & $(0.92)$ & $(-0.18)$ \\
\hline & S.D.* & {$[(0.32)\}$} & $(0.06)$ & $(0.17)$ & $(0.81)$ & $(0.33)$ & $(0.19)$ & $(0.12)$ & $(0.21)$ \\
\hline & Silver & -0.14 & 0.17 & 0.46 & -0.40 & -0.18 & -0.63 & 0.44 & 1.79 \\
\hline \multirow{8}{*}{$\ln \left(P_{i}{ }^{H a l} / P_{\text {Wheat }}^{H o l}\right)$} & Barley & 0.15 & -11.13 & 0.13 & -0.33 & 0.71 & -0.10 & 0.42 & -0.18 \\
\hline & Butter & 0.36 & -7.47 & -0.28 & -0.55 & 0.16 & -0.36 & 1.38 & 0.29 \\
\hline & Cheese & 0.41 & -11.83 & -0.03 & -0.12 & 0.35 & -0.10 & 0.92 & 1.10 \\
\hline & Oats & 0.22 & -20.68 & 0.22 & -0.74 & 0.74 & -0.02 & 0.76 & 0.00 \\
\hline & Peas & 0.23 & . & 0.12 & -0.23 & 0.31 & -0.18 & 0.53 & -0.12 \\
\hline & Mean* & {$[(-1.05)]$} & $(-12.78)$ & $(0.03)$ & $(-0.39)$ & $(0.45)$ & $(-0.15)$ & $(0.80)$ & $(0.22)$ \\
\hline & S.D.* & {$[(0,71)]$} & $(3.24)$ & $(0.10)$ & $(0.13)$ & $(0.13)$ & $(0.06)$ & $(0.19)$ & $(0.26)$ \\
\hline & Silver & -0.25 & -14.75 & 0.19 & -1.47 & -0.01 & -0.59 & -0.03 & 1.74 \\
\hline \multirow{2}{*}{$\ln \left(P_{i}^{U K}\right)$} & Mean" & {$[(-0.03)]$} & $(-0.28)$ & $(-0.27)$ & $(0.92)$ & $(0.37)$ & $(0.46)$ & $(0.34)$ & $(-2.39)$ \\
\hline & S.D.* & {$[(0.35)]$} & $(0.06)$ & $(0.14)$ & $(0.30)$ & $(0.24)$ & $(0.16)$ & $(0.20)$ & $(0.37)$ \\
\hline \multirow{2}{*}{$\ln \left(P_{i} / I^{\circ}\right)$} & Mean* & {$[(0.40)]$} & $(2.36)$ & $(-0.06)$ & $(1.14)$ & $(0.14)$ & $(0.56)$ & $(0.76)$ & $(-1.57)$ \\
\hline & S.D.* & {$[(0.39)]$} & $(2.75)$ & $(0.09)$ & $(0.11)$ & $(0.06)$ & $(0.10)$ & $(0.22)$ & $(0.21)$ \\
\hline
\end{tabular}

Average trend across three regression specifications: (a) constant and time trend; (b) constant, transitory war dumny, transitory filague dun trend; and (c) constant, transitory war dummy, transitory plague dummy, permanent war and plague dummies, and time trend. These estima estimates obtained using a single Cochrane-Orcutt iteration. The first-order autocorrelation coeflicient of the OI.S residuals was used to mak

"Single-bracketed figures in the rows labelled "Mean" and "S.D." give the sample mean and accompanying standard error of trend estimates prices in that eategory and century (i.e. barley, butter, cheese, oats, peas and wheat in the category In( $\left.P_{i} U K / P_{i} H o l\right)$. 'The double bracketed for Mean and $S$, D. in the column Jabeled 1273-1991 represent the mean and associated standard crror of trend estinates across all seven cent periods and commodities in a given cutegory. 
Table 4: English and Dutch commodity prices 1273-1991: Average standard error of trend coefficients, times 100

\begin{tabular}{|c|c|c|c|c|c|c|c|c|c|c|}
\hline Calegory & lndex & $1273-1991$ & $1273-1399$ & $1400-1499$ & $1500-1599$ & $1600-1699$ & $1700-1799$ & $1800-1899$ & $1900-1991$ & $1973-1991$ \\
\hline \multirow{8}{*}{$\ln \left(P_{i} U K / P_{i} H o l\right)$} & Barley & 0.10 & 1.67 & 0.70 & 0.89 & 0.92 & 0.49 & 0.37 & 0.88 & 4.93 \\
\hline & Butter & 0.14 & . & . & 0.83 & 0.44 & 0.28 & 0.31 & 0.84 & 5.13 \\
\hline & Cheese & 0.13 & & . & 2.32 & 0.76 & 0.44 & 0.33 & 0.70 & 9.50 \\
\hline & Oats & 0.08 & 1.98 & 0.62 & 0.79 & 0.78 & 0.35 & 0.46 & 0.57 & 4.30 \\
\hline & Peas & 0.09 & $\mathbf{3 . 3 3}$ & 0.81 & 1.13 & 0.69 & 0.41 & 0.41 & 0.72 & 6.01 \\
\hline & Wheat & 0.10 & 9.66 & 0.85 & 0.94 & 0.51 & 0.27 & 0.40 & 0.82 & 3.19 \\
\hline & Traded & 0.08 & . & 0.65 & 0.91 & 0.80 & 0.35 & 0.25 & 0.77 & 4.18 \\
\hline & Nontrad. & 0.26 & . & . & 1.77 & 1.18 & 0.36 & 0.78 & 0.59 & 10.28 \\
\hline \multirow{6}{*}{$\ln \left(P_{i}^{U K} / P \underset{\text { Wheal }}{U K}\right)$} & Barley & 0.07 & 0.15 & 0.52 & 0.89 & 0.50 & 0.52 & 0.22 & 0.68 & 1.21 \\
\hline & Butter & 0.12 & . & . & 2.17 & 0.56 & 0.46 & 0.36 & 0.81 & 3.96 \\
\hline & Cheese & 0.14 & . & . & 2.60 & 0.95 & 0.33 & 0.31 & 0.60 & 3.06 \\
\hline & Onts & 0.06 & 0.19 & 0.57 & 0.76 & 0.50 & 0.34 & 0.26 & 0.36 & 1.03 \\
\hline & Peas & 0.09 & 0.19 & 0.68 & 0.91 & 0.54 & 0.31 & 0.64 & 0.63 & 3.48 \\
\hline & Silver & 0.12 & 0.39 & 0.72 & 0.98 & 0.67 & 0.45 & 0.34 & 0.98 & 4.65 \\
\hline \multirow{6}{*}{$\ln \left(P_{i}{ }^{H o l} / P\right.$ Wheal $)$} & Barley & 0.07 & 8.79 & 0.58 & 0.60 & 0.56 & 0.27 & 0.26 & 0.72 & 4.25 \\
\hline & Butter & 0.12 & 2.98 & 0.75 & 0.81 & 0.58 & 0.36 & 0.49 & 0.56 & 1.90 \\
\hline & Cheese & 0.11 & 5.69 & 0.64 & 0.88 & 0.53 & 0.38 & 0.44 & 0.92 & 2.87 \\
\hline & Onts & 0.07 & 13.45 & 0.60 & 0.63 & 0.65 & 0.38 & 0.24 & 0.50 & 1.44 \\
\hline & Peas & 0.08 & . & 0.77 & 0.72 & 0.53 & 0.41 & 0.47 & 0.70 & 5.24 \\
\hline & Silver & 0.14 & 11.46 & 0.93 & 0.81 & 0.77 & 0.44 & 0.52 & 1.18 & 6.13 \\
\hline
\end{tabular}

A verage of GLS standard errors on the trend coefficient across three regression specifications: (a) constant and time trend; (b) constant, transitory war dummy, transitory plague dummy and time trend; and (c) constant, transitory war dummy, transitory plague dummy, permanent war and plague dummies, and time trend. Figure shown is 100 times the average. 
Table 5: English and Dutch commodity prices 1273-1991: Dispersion of average trend times 100

\begin{tabular}{|c|c|c|c|c|c|c|c|c|c|}
\hline Category & Index & $1273-1991$ & 1273-1399 & $1400-1499$ & $1500-1599$ & $1600-1699$ & $1700-1799$ & $1800-1899$ & $1900-1991$ \\
\hline \multirow{8}{*}{$\ln \left(P_{i} U K / P_{i} H_{0 l}\right)$} & Barley & 0.23 & 0.79 & 0.52 & 0.16 & 0.40 & 0.13 & 0.08 & 0.28 \\
\hline & Butter & 0.17 & . & . & . & 0.24 & 0.13 & 0.02 & 0.09 \\
\hline & Cheese & 0.18 & . & & & 0.24 & 0.06 & 0.06 & 0.18 \\
\hline & Oats & 0.20 & 1.85 & 0.69 & 0.11 & 0.36 & 0.03 & 0.05 & 0.20 \\
\hline & Peas & 0.05 & 0.22 & 0.28 & 1.60 & 0.50 & 0.22 & 0.07 & 0.20 \\
\hline & Wheat & 0.20 & . & 0.75 & 1.86 & 0.09 & 0.06 & 0.08 & 0.23 \\
\hline & Traded & 0.18. & . & 0.38 & 1.64 & 0.67 & 0.15 & 0.05 & 0.49 \\
\hline & Nontrad. & 0.19 & . & • & & 0.84 & 0.00 & 0.05 & 0.08 \\
\hline \multirow{6}{*}{$\ln \left(P_{i}^{U K} / P \underset{W h \text { eat }}{U K}\right)$} & Barley & 0.07 & 0.02 & 0.15 & 1.30 & 0.13 & 0.07 & 0.03 & 0.21 \\
\hline & Butter & 0.20 & . & . & . & 0.35 & 0.15 & 0.10 & 0.16 \\
\hline & Cheese & 0.11 & & . & . & 0.05 & 0.08 & 0.02 & 0.23 \\
\hline & Oats & 0.14 & 0.00 & 0.12 & 1.65 & 0.02 & 0.04 & 0.03 & 0.08 \\
\hline & Peas & 0.18 & 0.02 & 0.47 & 0.13 & 0.38 & 0.06 & 0.07 & 0.12 \\
\hline & Silver & 0.23 & 0.04 & 0.04 & 1.20 & 0.21 & 0.12 & 0.03 & 0.53 \\
\hline \multirow{6}{*}{$\ln \left(P_{i}^{H o l} / P P_{W h \text { cat }}^{H o l}\right)$} & Barley & 0.11 & . & 0.01 & 0.54 & 0.53 & 0.03 & 0.01 & 0.31 \\
\hline & Butter & 0.25 & . & 0.08 & 0.65 & 0.01 & 0.05 & 0.09 & 0.18 \\
\hline & Cheese & 0.24 & . & 0.10 & 0.44 & 0.26 & 0.04 & 0.04 & 0.16 \\
\hline & Oats & 0.18 & . & 0.01 & 0.57 & 0.31 & 0.10 & 0.02 & 0.17 \\
\hline & Peas & 0.15 & . & 0.21 & 0.43 & 0.03 & 0.10 & 0.04 & 0.06 \\
\hline & Silver & 0.06 & . & 0.64 & 0.47 & 0.16 & 0.07 & 0.04 & 0.26 \\
\hline
\end{tabular}

"Dispersion" of average trend across three regression specifications: (a) constant and time trend; (b) constant, transitory war dummy, transitory plague dummy and time trend; and (c) constant, transitory war dummy, transitory plague dummy, permanent war and plague dummies, and tirne trend. Dispersion is measured as the simple standard deviation of the three coefficients, times 100. 
Table 6: English and Dutch commodity prices 1273-1991: Average first order autocorrelation coefficient of OLS residuals

\begin{tabular}{|c|c|c|c|c|c|c|c|c|c|c|}
\hline Category & Index & $1273-1991$ & $1273-1399$ & $1400-1499$ & $1500-1599$ & $1600-1699$ & $1700-1799$ & $1800-1899$ & $1900-1991$ & $1973-1991$ \\
\hline \multirow{8}{*}{$\ln \left(P_{i} U K^{\prime} / P_{i}{ }^{H o l}\right)$} & Barley & 0.62 & -0.16 & 0.38 & 0.09 & 0.36 & 0.63 & 0.55 & 0.70 & 0.63 \\
\hline & Butter & 0.75 & . & 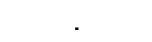 & -0.26 & 0.41 & 0.48 & 0.77 & 0.66 & 0.51 \\
\hline & Cheese & 0.65 & . & . & -0.11 & 0.43 & 0.64 & 0.70 & 0.60 & 0.62 \\
\hline & Oats & 0.54 & 0.21 & 0.20 & 0.21 & 0.27 & 0.31 & 0.67 & 0.67 & 0.54 \\
\hline & Peas & 0.43 & 0.08 & 0.08 & 0.18 & 0.34 & 0.39 & 0.60 & 0.24 & 0.28 \\
\hline & Wheat & 0.64 & -0.26 & 0.49 & 0.36 & 0.41 & 0.32 & 0.66 & 0.72 & 0.44 \\
\hline & Traded & 0.46 & . & 0.14 & 0.14 & 0.39 & 0.26 & 0.38 & 0.41 & 0.25 \\
\hline & Nontrad. & 0.81 & . & . & -0.61 & 0.15 & 0.31 & 0.81 & 0.62 & 0.67 \\
\hline \multirow{6}{*}{$\ln \left(P_{i} U K / P \underset{W h \text { eat }}{U K}\right)$} & Barley & 0.58 & 0.19 & 0.18 & 0.03 & 0.38 & 0.73 & 0.58 & 0.75 & 0.34 \\
\hline & Butter & 0.72 & . & . & 0.34 & 0.44 & 0.62 & 0.69 & 0.64 & 0.29 \\
\hline & Cheese & 0.70 & . & & 0.03 & 0.55 & 0.44 & 0.61 & 0.60 & 0.25 \\
\hline & Oats & 0.52 & 0.21 & 0.14 & 0.05 & 0.39 & 0.45 & 0.62 & 0.47 & 0.03 \\
\hline & Peas & 0.64 & 0.26 & 0.21 & -0.20 & 0.36 & 0.44 & 0.82 & 0.24 & 0.30 \\
\hline & Silver & 0.82 & 0.59 & 0.47 & 0.44 & 0.60 & 0.64 & 0.58 & 0.79 & 0.50 \\
\hline \multirow{6}{*}{$\ln \left(P_{i}^{H o l} / P_{\text {Wheat }}^{H o l}\right)$} & Barley & 0.54 & -0.04 & 0.18 & 0.22 & 0.11 & 0.21 & 0.50 & 0.63 & 0.51 \\
\hline & Butter & 0.78 & -0.08 & 0.46 & 0.36 & 0.51 & 0.52 & 0.73 & 0.65 & 0.35 \\
\hline & Cheese & 0.73 & -0.00 & 0.17 & 0.47 & 0.45 & 0.50 & 0.66 & 0.80 & 0.56 \\
\hline & Oats & 0.57 & -0.04 & 0.27 & 0.24 & 0.26 & 0.34 & 0.52 & 0.49 & -0.05 \\
\hline & Peas & 0.49 & & 0.16 & 0.13 & 0.16 & 0.38 & 0.66 & 0.58 & 0.51 \\
\hline & Silver & 0.83 & -0.07 & 0.61 & 0.55 & 0.69 & 0.65 & 0.71 & 0.82 & 0.48 \\
\hline
\end{tabular}

A verage first-order autocorrelation coefficient of OLS residuals across six regression specifications: (a) constant; (b) constant, transitory war dummy and transitory plague dummy; (c) constant, transitory war dummy, transitory plague dummy, and permanent war and plague dummies; and (d) specifications (a) through (c) run with a time trend. 
Table 7: English and Dutch commodity prices 1273-1991: Volatility around "theoretical" value

\begin{tabular}{|c|c|c|c|c|c|c|c|c|c|}
\hline Calegory & Index & $1273-1991$ & $1273 \sim 1399$ & $1400-1499$ & $1500-1599$ & $1600-1699$ & $1700-1799$ & $1800-1899$ & $1900-1991$ \\
\hline \multirow{10}{*}{$\ln \left(P_{i}{ }^{U K} / P_{i}{ }^{H o l}\right)$} & Barley & 0.42 & 0.25 & 0.34 & 0.39 & 0.46 & 0.64 & 0.35 & 0.32 \\
\hline & Butter & $\mathbf{0 . 3 3}$ & . & . & 0.19 & 0.24 & 0.33 & 0.41 & 0.36 \\
\hline & Cheese & 0.54 & & & 1.30 & 0.62 & 0.37 & 0.60 & 0.29 \\
\hline & Oats & 0.35 & 0.32 & 0.41 & 0.35 & 0.32 & 0.34 & 0.44 & 0.21 \\
\hline & Peas & 0.65 & 0.76 & 1.00 & 0.70 & 0.76 & 0.46 & 0.31 & 0.34 \\
\hline & Wheat & 0.37 & 0.37 & 0.52 & 0.51 & 0.24 & 0.21 & 0.27 & 0.34 \\
\hline & Traded & 0.35 & & 0.54 & 0.47 & 0.25 & 0.19 & 0.18 & 0.23 \\
\hline & Nontrad. & 0.56 & & & 0.23 & 0.43 & 0.71 & 0.71 & 0.27 \\
\hline & Mean Corr. * & {$[(0.53)]$} & $(0.52)$ & $(0.63)$ & $(0.62)$ & $(0.43)$ & $(0.36)$ & $(0.57)$ & $(0.60)$ \\
\hline & S.E. Corr. ${ }^{*}$ & {$[(0.08)]$} & $(0.17)$ & $(0.11)$ & $(0.07)$ & $(0.10)$ & $(0.10)$ & $(0.08)$ & $(0.07)$ \\
\hline
\end{tabular}

Simple standard deviation of each price series about its theoretical value of 0 .

" Figures in the row labelled "Mean Cors." give the average of the pairwise correlation coefficients between the individual cornmodity price se Figures in the row labelled "S.E. Corr." are approximate standard errors for the "Mean Corr." estimates, calculated on the assumption that $t$ distributed normally. Single-bracketed estimates correspond to a single century-long period, while the double-bracketed figures are calculated across all eight century-long periods. 
Talile 8: English and Dutch commodity prices 1273-1991: Average conditional volatility

\begin{tabular}{|c|c|c|c|c|c|c|c|c|c|}
\hline Category & Index & $1273-1991$ & $1273-1399$ & $1400-1499$ & $1500-1599$ & $1600-1699$ & $1700-1799$ & $1800-1899$ & $1900-199$ \\
\hline \multirow{10}{*}{$\ln \left(P_{i} U K^{\prime} / P_{i}^{H o l}\right)$} & Barley & 0.34 & 0.23 & 0.26 & 0.27 & 0.30 & 0.25 & 0.20 & 0.28 \\
\hline & Butter & 0.25 & . & . & 0.17 & 0.17 & 0.14 & 0.16 & 0.29 \\
\hline & Cheese & 0.30 & . & . & 0.47 & 0.35 & 0.19 & 0.17 & 0.22 \\
\hline & Orts & 0.29 & 0.26 & 0.27 & 0.23 & 0.20 & 0.19 & 0.26 & 0.17 \\
\hline & Pens & 0.36 & 0.34 & 0.36 & 0.32 & 0.35 & 0.31 & 0.24 & 0.29 \\
\hline & Wheat & 0.30 & 0.16 & 0.30 & 0.30 & 0.20 & 0.18 & 0.23 & 0.28 \\
\hline & Traded & 0.24 & . & 0.22 & 0.21 & 0.18 & 0.17 & 0.16 & 0.22 \\
\hline & Nontrad. & 0.32 & & & 0.20 & 0.17 & 0.15 & 0.37 & 0.17 \\
\hline & Mean Corr. & {$[(0.50)]$} & $(0.57)$ & $(0.63)$ & $(0.58)$ & $(0.43)$ & $(0.38)$ & $(0.55)$ & $(0.58)$ \\
\hline & S.E. Corr. * & {$[(0.03)]$} & $(0.08)$ & $(0.04)$ & $(0.04)$ & $(0.04)$ & $(0.04)$ & $(0.03)$ & $(0.04)$ \\
\hline \multirow{8}{*}{$\ln \left(P_{i} U K / P \underset{W h e a t}{U K}\right)$} & Barley & 0.26 & 0.15 & 0.18 & 0.29 & 0.25 & 0.27 & 0.17 & 0.21 \\
\hline & Butter & 0.31 & . & . & 0.30 & 0.23 & 0.22 & 0.25 & 0.28 \\
\hline & Cheese & 0.39 & . & . & 0.49 & $\mathbf{0 . 3 5}$ & 0.20 & 0.23 & 0.20 \\
\hline & Oats & 0.24 & 0.20 & 0.22 & 0.24 & 0.18 & 0.20 & 0.18 & 0.13 \\
\hline & Peas & 0.37 & 0.21 & 0.25 & 0.31 & 0.24 & 0.17 & 0.35 & 0.29 \\
\hline & Silver & 0.49 & 0.30 & 0.23 & 0.32 & 0.21 & 0.24 & 0.21 & 0.44 \\
\hline & Mean Corr. & {$[(0.68)]$} & $(0.77)$ & $(0.78)$ & $(0.78)$ & $(0.61)$ & $(0.71)$ & $(0.69)$ & $(0.58)$ \\
\hline & S.E. Corr. & $\{(0.02)\}$ & $(0.04)$ & $(0.04)$ & $(0.03)$ & $(0.03)$ & $(0.03)$ & $(0.03)$ & $(0.04)$ \\
\hline \multirow[t]{8}{*}{$\ln \left(P_{i} U K^{\prime} / P \underset{W h e a t}{U K}\right)$} & Barley & 0.20 & 0.13 & 0.20 & 0.14 & 0.14 & 0.13 & 0.15 & 0.21 \\
\hline & Butter & 0.34 & 0.09 & 0.25 & 0.19 & 0.20 & 0.22 & 0.32 & 0.16 \\
\hline & Cheese & 0.37 & 0.12 & 0.26 & 0.20 & 0.23 & 0.22 & 0.29 & 0.30 \\
\hline & Oals & 0.24 & 0.26 & 0.22 & 0.15 & 0.17 & 0.20 & 0.21 & 0.17 \\
\hline & Peas & 0.31 & & 0.30 & 0.18 & 0.28 & 0.31 & 0.28 & 0.26 \\
\hline & Silver & 0.42 & 0.19 & 0.30 & 0.23 & 0.24 & 0.24 & 0.25 & 0.43 \\
\hline & Mean Corr. & {$[(0.68)]$} & $(0.72)$ & $(0.67)$ & $(0.66)$ & $(0.61)$ & $(0.60)$ & $(0.67)$ & $(0.64)$ \\
\hline & S.E. Corr ${ }^{*}$ & {$[(0.02)]$} & $(0.08)$ & $(0.02)$ & $(0.02)$ & $(0.04)$ & $(0.03)$ & $(0.03)$ & $(0.04)$ \\
\hline
\end{tabular}

Average regression standard error across six $O L S$ regression specifications: (a) constant; (b) constant, transitory war dummy and transitory (c) constant, transitory war dummy, transitory plague dummy, and pernanent war and plague dummies; and (d) specifications (a) - (c) run "Figures in the rows labelled "Mean Corr." give the average of the pairwise correlation coefficients between the individual comrnodity price s Figures in the rows labelled "S.E. Corr." are approximate standard errors for the "Mean Corr." estimates, calculated on the assumption that distributed normally. Single-bracketed estimates correspond to a single century-long period, while the double-bracketed figures are calculated across all eight century-long periods. 
Table 9: English and Dutch commodity prices 1273-1991: Dispersion of conditional volatility

\begin{tabular}{|c|c|c|c|c|c|c|c|c|c|c|}
\hline Category & Index & $1273-1991$ & $1273-1399$ & $1400-1499$ & $1500-1599$ & $1600-1699$ & $1700-1799$ & $1800-1899$ & $1900-1991$ & $1973-1991$ \\
\hline \multirow{8}{*}{$\ln \left(P_{i} U K / P_{i}{ }^{H \circ l}\right)$} & Barley & 0.07 & 0.01 & 0.02 & 0.01 & 0.06 & 0.05 & 0.01 & 0.01 & 0.01 \\
\hline & Butter & 0.04 & . & . & 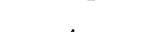 & 0.02 & 0.01 & 0.06 & 0.01 & 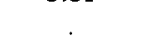 \\
\hline & Cheese & 0.06 & & & . & 0.10 & 0.00 & 0.03 & 0.01 & \\
\hline & Oats & 0.05 & 0.03 & 0.02 & 0.03 & 0.01 & 0.00 & 0.02 & 0.02 & 0.00 \\
\hline & Peas & 0.07 & . & 0.02 & 0.04 & 0.02 & 0.02 & 0.00 & 0.01 & \\
\hline & Wheat & 0.05 & . & 0.03 & 0.03 & 0.02 & 0.00 & 0.02 & 0.00 & 0.00 \\
\hline & Traded & 0.05 & . & 0.02 & 0.04 & 0.03 & 0.01 & 0.01 & 0.02 & . \\
\hline & Nontrad. & 0.05 & . & . & & & 0.02 & 0.11 & 0.03 & \\
\hline \multirow{6}{*}{$\ln \left(P_{i} U K / P \underset{W h e a l}{U K}\right)$} & Barley & 0.03 & 0.01 & 0.01 & 0.01 & 0.04 & 0.05 & 0.05 & 0.01 & 0.01 \\
\hline & Butter & 0.07 & . & . & . & 0.02 & 0.01 & 0.06 & 0.02 & . \\
\hline & Cheese & 0.12 & . & . & - & 0.09 & 0.01 & 0.05 & 0.03 & r \\
\hline & Oats & 0.03 & 0.00 & 0.01 & 0.02 & 0.01 & 0.00 & 0.05 & 0.00 & 0.00 \\
\hline & Peas & 0.09 & 0.01 & 0.01 & 0.02 & 0.01 & 0.00 & 0.07 & 0.01 & \\
\hline & Silver & 0.20 & 0.01 & 0.02 & 0.08 & 0.02 & 0.03 & 0.02 & 0.09 & 0.13 \\
\hline \multirow{6}{*}{$\ln \left(P_{i}{ }^{H o l} / P P_{W k_{\text {eat }}}^{H o l}\right)$} & Barley & 0.03 & . & 0.00 & 0.01 & 0.01 & 0.00 & 0.02 & 0.01 & 0.00 \\
\hline & Butter & 0.08 & . & 0.02 & 0.01 & 0.01 & 0.01 & 0.07 & 0.01 & 0.01 \\
\hline & Cheese & 0.11 & . & 0.01 & 0.02 & 0.03 & 0.00 & 0.04 & 0.03 & 0.08 \\
\hline & Oats & 0.04 & . & 0.02 & 0.01 & 0.02 & 0.00 & 0.05 & 0.01 & 0.00 \\
\hline & Peas & 0.04 & . & 0.01 & 0.01 & 0.01 & 0.01 & 0.02 & 0.01 & 0.00 \\
\hline & Silver & 0.15 & . & 0.03 & 0.09 & 0.02 & 0.03 & 0.01 & 0.07 & 0.14 \\
\hline
\end{tabular}

Standard deviation of regression standard error across six OLS regression specifications: (a) constant; (b) constant, transitory war dummy and transitory plague dummy; (c) constant, transitory war dummy, transitory plague dummy, and permanent war and plague dummies; and (d) specifications (a) through (c) run with a time trend. 
Table 10: Augmented Dickey-Fuller tests for English and Dutch commodity prices, 1273-1991

\begin{tabular}{|c|c|c|c|c|c|}
\hline \multirow[t]{2}{*}{ Category } & \multirow[t]{2}{*}{ Good } & \multicolumn{2}{|c|}{ Annusl } & \multicolumn{2}{|c|}{ 5-year } \\
\hline & & No trend & Trend & No trend & Trend \\
\hline \multirow[t]{3}{*}{$\ln \left(P_{i}^{U K} / P_{i}^{H o l}\right)$} & Barley & $\begin{array}{l}0.759^{*} \\
(0.038)\end{array}$ & $\begin{array}{c}0.746^{*} \\
(0.036)\end{array}$ & $\begin{array}{l}0.654^{*} \\
(0.094)\end{array}$ & $\begin{array}{l}0.612^{*} \\
(0.084)\end{array}$ \\
\hline & Butter & $\begin{array}{c}0.809^{*} \\
(0.034)\end{array}$ & $\begin{array}{c}0.803^{*} \\
(0.034)\end{array}$ & $\begin{array}{c}0.898 \\
(0.068)\end{array}$ & $\begin{array}{c}0.874 \\
(0.082)\end{array}$ \\
\hline & Wheat & $\begin{array}{l}0.803^{*} \\
(0.025)\end{array}$ & $\begin{array}{l}0.779^{*} \\
(0.028)\end{array}$ & $\begin{array}{l}0.577^{*} \\
(0.089)\end{array}$ & $\begin{array}{l}0.521^{*} \\
(0.095)\end{array}$ \\
\hline \multirow{2}{*}{$\ln \left(P_{i}^{U K} / P \underset{W h e a t}{U K}\right)$} & Barley & $0.598^{*}$ & $0.583^{*}$ & $0.655^{\circ}$ & $0.632^{\circ}$ \\
\hline & Butter & $\begin{array}{c}(0.038) \\
0.888^{*} \\
(0.018)\end{array}$ & $\begin{array}{c}(0.038) \\
0.797^{\circ} \\
(0.027)\end{array}$ & $\begin{array}{c}(0.060) \\
0.710 \\
(0.094)\end{array}$ & $\begin{array}{l}(0.061) \\
0.443^{*} \\
(0.109)\end{array}$ \\
\hline \multirow[t]{2}{*}{$\ln \left(P_{i}^{H o l} / P_{\text {Wheat }}^{\text {Hol }}\right)$} & Barley & $\begin{array}{l}0.689^{*} \\
(0.030)\end{array}$ & $\begin{array}{l}0.620^{*} \\
(0.034)\end{array}$ & $\begin{array}{l}0.694^{*} \\
(0.072)\end{array}$ & . \\
\hline & Butter & $\begin{array}{l}0.892^{*} \\
(0.015)\end{array}$ & $\begin{array}{l}0.835^{*} \\
(0.019)\end{array}$ & $\begin{array}{l}0.735^{*} \\
(0.066)\end{array}$ & $\begin{array}{l}0.539^{*} \\
(0.077)\end{array}$ \\
\hline \multirow[t]{3}{*}{$\ln \left(P_{i}^{U K}\right)$} & Barley & $\begin{array}{l}0.957^{\circ} \\
(0.008)\end{array}$ & $\begin{array}{l}0.901^{*} \\
(0.013)\end{array}$ & $\begin{array}{c}0.944 \\
(0.034)\end{array}$ & $\begin{array}{c}0.895 \\
(0.054)\end{array}$ \\
\hline & Butter & $\begin{array}{c}0.938 \\
(0.024)\end{array}$ & $\begin{array}{c}0.794 \\
(0.038)\end{array}$ & 0.999 & . \\
\hline & Wheat & $\begin{array}{l}0.940^{*} \\
(0.010)\end{array}$ & $\begin{array}{l}0.872^{*} \\
(0.015)\end{array}$ & $\begin{array}{l}0.847^{*} \\
(0.041)\end{array}$ & $\begin{array}{l}0.710^{*} \\
(0.063)\end{array}$ \\
\hline \multirow[t]{4}{*}{$\ln \left(P_{i} H \circ\right)$} & Barley & $\begin{array}{c}0.999 \\
(0.014)\end{array}$ & $\begin{array}{l}0.874^{*} \\
(0.022)\end{array}$ & $\begin{array}{c}0.832 \\
(0.063)\end{array}$ & $\begin{array}{c}0.961 \\
(0.018)\end{array}$ \\
\hline & Butter & 0.988 & $0.917^{\circ}$ & 0.999 & $0.969^{\circ}$ \\
\hline & & $(0.010)$ & $(0.016)$ & & $(0.007)$ \\
\hline & Wheat & $\begin{array}{c}0.997 \\
(0.008)\end{array}$ & $\begin{array}{l}0.869^{\circ} \\
(0.016)\end{array}$ & $\begin{array}{l}0.785^{*} \\
(0.058)\end{array}$ & $\begin{array}{l}0.627^{*} \\
(0.086)\end{array}$ \\
\hline
\end{tabular}

Estimated coefficient $\rho_{1}$ from the specification $y_{t}=\delta_{0}+\rho_{1} y_{t-1}+\zeta_{1} \Delta y_{t-1}+\zeta_{2} \Delta y_{t-2}+e_{t}$. Standard error in parentheses. Trends were included by adding a trend term $\delta_{1} t$ to the specification. An * denotes a coefficient that is significantly different from 1 at the 1 percent level. Estimation is carried out using the Kalman filter to cater to the presence of missing observations. 
Table 11: AR(1) estimates for English and Dutch commodity prices, 1273-1991

\begin{tabular}{|c|c|c|c|c|c|}
\hline \multirow[t]{2}{*}{ Category } & \multirow[t]{2}{*}{ Good } & \multirow{2}{*}{$\begin{array}{c}\text { 5-year } \\
\rho_{1}\end{array}$} & \multicolumn{3}{|c|}{ Annual } \\
\hline & & & $\rho_{1}$ & $\rho_{2}$ & $\rho_{3}$ \\
\hline \multirow[t]{3}{*}{$\ln \left(P_{i} U K / P_{i}^{H o l}\right)$} & Barley & $\begin{array}{c}0.672 \\
(0.065)\end{array}$ & $\begin{array}{c}0.839 \\
(0.022)\end{array}$ & $\begin{array}{l}-0.097 \\
(0.091)\end{array}$ & $\begin{array}{l}-0.035 \\
(0.221)\end{array}$ \\
\hline & Butter & $\begin{array}{c}0.761 \\
(0.068)\end{array}$ & $\begin{array}{c}0.894 \\
(0.024)\end{array}$ & $\begin{array}{c}0.032 \\
(0.060)\end{array}$ & $\begin{array}{l}-0.136 \\
(0.081)\end{array}$ \\
\hline & Wheat & $\begin{array}{c}0.628 \\
(0.071)\end{array}$ & $\begin{array}{c}0.784 \\
(0.027)\end{array}$ & $\begin{array}{c}0.048 \\
(0.075)\end{array}$ & $\begin{array}{l}-0.118 \\
(0.228)\end{array}$ \\
\hline \multirow{3}{*}{$\ln \left(P_{i}^{U K} / P_{\text {Wheat }}^{U K}\right)$} & Barley & 0.508 & 0.630 & 0.290 & 0.250 \\
\hline & & $(0.072)$ & $(0.030)$ & $(0.070)$ & $(0.373)$ \\
\hline & Butter & $\begin{array}{c}0.341 \\
(0.105)\end{array}$ & $\begin{array}{c}0.693 \\
(0.039)\end{array}$ & $\begin{array}{c}0.111 \\
(0.087)\end{array}$ & $\begin{array}{c}0.088 \\
(0.195)\end{array}$ \\
\hline \multirow{4}{*}{$\ln \left(P_{i} H^{H o l} / P \underset{\text { Wheat }}{H o l}\right)$} & Barley & 0.399 & 0.455 & 0.419 & 0.499 \\
\hline & & $(0.085)$ & $(0.040)$ & $(0.059)$ & $(0.096)$ \\
\hline & Butter & 0.636 & 0.745 & 0.231 & 0.267 \\
\hline & & $(0.073)$ & $(0.029)$ & $(0.044)$ & $(0.070)$ \\
\hline \multirow[t]{3}{*}{$\ln \left(P_{i}^{U K}\right)$} & Barley & $\begin{array}{c}0.784 \\
(0.053)\end{array}$ & $\begin{array}{c}0.881 \\
(0.021)\end{array}$ & $\begin{array}{c}0.081 \\
(0.037)\end{array}$ & $\begin{array}{c}0.020 \\
(0.098)\end{array}$ \\
\hline & Butter & $\begin{array}{c}0.811 \\
(0.065)\end{array}$ & $\begin{array}{c}0.793 \\
(0.038)\end{array}$ & $\begin{array}{c}0.169 \\
(0.043)\end{array}$ & $\begin{array}{l}0.115 \\
(0.069)\end{array}$ \\
\hline & Wheat & $\begin{array}{c}0.700 \\
(0.061)\end{array}$ & $\begin{array}{c}0.851 \\
(0.021)\end{array}$ & $\begin{array}{c}0.019 \\
(0.066)\end{array}$ & $\begin{array}{c}0.084 \\
(0.064)\end{array}$ \\
\hline \multirow[t]{4}{*}{$\ln \left(P_{i}{ }^{H o l}\right)$} & Barley & $\begin{array}{c}0.625 \\
(0.072)\end{array}$ & $\begin{array}{c}0.823 \\
(0.026)\end{array}$ & $\begin{array}{c}0.158 \\
(0.032)\end{array}$ & $\begin{array}{l}-0.177 \\
(0.098)\end{array}$ \\
\hline & Butter & 0.884 & 0.951 & 0.045 & -0.341 \\
\hline & & $(0.043)$ & $(0.023)$ & $(0.027)$ & $(0.070)$ \\
\hline & Wheat & $\begin{array}{c}0.578 \\
(0.076)\end{array}$ & $\begin{array}{c}0.829 \\
(0.025)\end{array}$ & $\begin{array}{c}0.123 \\
(0.051)\end{array}$ & $\begin{array}{c}0.067 \\
(0.082)\end{array}$ \\
\hline
\end{tabular}

Column 1: Estimated coefficient $\rho_{1}$ from the specification $y_{t}=\delta_{0}+\delta_{1} t+\rho_{1} y_{t-1}+e_{t}$, where $y_{t}$ is every fifth observation. Columns 2-4: Estimated coefficients $\rho_{1}, \rho_{2}$ and $\rho_{3}$ from the specification $y_{t}=\delta_{0}+\delta_{1} t+\rho_{1} y_{t-1}+\rho_{2} D_{1900,1972} y_{t-1}+\rho_{4} D_{1973,1991} y_{t-1}+e_{t}$, where $D_{s, t}$ is a dummy variable taking the value 1 for the years $s$ through $t$, and 0 otherwise. Thus $\rho_{2}$ and $\rho_{3}$ capture the increments over $\rho_{1}$ of the first-order autoregressive coefficient in each of two subsamples, 1900-1991 and 1973-1991. Standard errors in parentheses. For $\ln \left(P_{i} U K / P_{i}{ }^{H o l}\right)$, the mean and trend coefficients are constrained to equal 0 , as the price indices in this category represent real exchange rates. Estimation is carried out using the Kalman filter to cater to the presence of missing observations. 
Table A.1: Relative English/Dutch commodity prices in log grams of silver, 1273-1991: Average coefficient on war dummies.

\begin{tabular}{|c|c|c|c|c|c|c|c|}
\hline War & Period & Barley & Butter & Cheese & Oats & Peas & Wheat \\
\hline \multirow[t]{9}{*}{ Wars } & $1273-1991$ & $\begin{array}{c}0.10 \\
(0.14)\end{array}$ & $\begin{array}{c}0.02 \\
(0.13)\end{array}$ & $\begin{array}{c}-0.06 \\
(0.15)\end{array}$ & $\begin{array}{c}0.12 \\
(0.12)\end{array}$ & $\begin{array}{c}0.15 \\
(0.12)\end{array}$ & $\begin{array}{c}0.09 \\
(0.12)\end{array}$ \\
\hline & $1273-1399$ & & . & . & . & 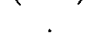 & $8=8$ \\
\hline & $1400-99$ & $\begin{array}{c}-0.04 \\
(0.34)\end{array}$ & . & . & $\begin{array}{c}-0.15 \\
(0.34)\end{array}$ & $\begin{array}{c}-0.07 \\
(0.41)\end{array}$ & $\begin{array}{c}-0.18 \\
(0.36)\end{array}$ \\
\hline & $1500-99$ & $\begin{array}{c}-0.06 \\
(0.20)\end{array}$ & . & . & $\begin{array}{c}0.07 \\
(0.20)\end{array}$ & $\begin{array}{c}-0.26 \\
(0.26)\end{array}$ & $\begin{array}{l}-0.10 \\
(0.26)\end{array}$ \\
\hline & $1600-99$ & . & $\begin{array}{c}-0.02 \\
(0.15)\end{array}$ & $\begin{array}{c}-0.01 \\
(0.25)\end{array}$ & . & $\begin{array}{c}0.17 \\
(0.22)\end{array}$ & $\begin{array}{c}0.13 \\
(0.17)\end{array}$ \\
\hline & $1700-99$ & -0.30 & 0.10 & -0.03 & 0.01 & 0.21 & 0.06 \\
\hline & & $(0.36)$ & $(0.20)$ & $(0.27)$ & $(0.28)$ & $(0.29)$ & $(0.19)$ \\
\hline & $1800-99$ & $\begin{array}{c}-0.10 \\
(0.28)\end{array}$ & $\begin{array}{c}-0.09 \\
(0.23)\end{array}$ & $\begin{array}{c}-0.05 \\
(0.25)\end{array}$ & $\begin{array}{c}0.16 \\
(0.33)\end{array}$ & $\begin{array}{c}0.11 \\
(0.28)\end{array}$ & $\begin{array}{c}-0.07 \\
(0.28)\end{array}$ \\
\hline & $1900-91$ & . & . & . & . & . & . \\
\hline \multirow[t]{2}{*}{ Roses } & $1273-1991$ & $\begin{array}{c}-0.13 \\
(0.47)\end{array}$ & . & . & $\begin{array}{c}0.08 \\
(0.43)\end{array}$ & $\begin{array}{c}0.14 \\
(0.50)\end{array}$ & $\begin{array}{c}-0.25 \\
(0.45)\end{array}$ \\
\hline & $1400-99$ & $\begin{array}{c}-0.26 \\
(0.65)\end{array}$ & . & . & $\begin{array}{c}-0.31 \\
(0.68)\end{array}$ & $\begin{array}{c}-0.22 \\
(0.78)\end{array}$ & $\begin{array}{c}-0.61 \\
(0.69)\end{array}$ \\
\hline \multirow[t]{3}{*}{ DutInd } & $1273-1991$ & -0.02 & . & . & -0.26 & 0.28 & -0.00 \\
\hline & & $(0.46)$ & . & . & $(0.42)$ & $(0.47)$ & $(0.44)$ \\
\hline & $1500-99$ & $\begin{array}{c}-0.14 \\
(0.40)\end{array}$ & 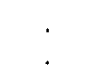 & . & $\begin{array}{c}-0.50 \\
(0.33)\end{array}$ & $\begin{array}{c}0.12 \\
(0.42)\end{array}$ & $\begin{array}{l}-0.02 \\
(0.42)\end{array}$ \\
\hline \multirow[t]{2}{*}{ EngCiv } & $1273-1991$ & $\begin{array}{c}0.08 \\
(0.33)\end{array}$ & $\begin{array}{c}0.03 \\
(0.32)\end{array}$ & $\begin{array}{c}-0.12 \\
(0.40)\end{array}$ & $\begin{array}{c}0.12 \\
(0.26)\end{array}$ & $\begin{array}{c}-0.20 \\
(0.28)\end{array}$ & $\begin{array}{c}0.20 \\
(0.31)\end{array}$ \\
\hline & $1600-99$ & $\begin{array}{c}-0.02 \\
(0.27)\end{array}$ & $\begin{array}{c}0.08 \\
(0.23)\end{array}$ & $\begin{array}{c}-0.22 \\
(0.41)\end{array}$ & $\begin{array}{c}0.12 \\
(0.25)\end{array}$ & $\begin{array}{c}-0.34 \\
(0.37)\end{array}$ & $\begin{array}{c}0.08 \\
(0.27)\end{array}$ \\
\hline \multirow[t]{2}{*}{ AngDut1 } & $1273-1991$ & $\begin{array}{c}-0.37 \\
(0.43)\end{array}$ & $\begin{array}{c}0.04 \\
(0.35)\end{array}$ & $\begin{array}{l}-0.10 \\
(0.46)\end{array}$ & $\begin{array}{c}-0.15 \\
(0.41)\end{array}$ & $\begin{array}{c}-0.03 \\
(0.41)\end{array}$ & $\begin{array}{c}-0.44 \\
(0.39)\end{array}$ \\
\hline & $1600-99$ & $\begin{array}{l}-0.50 \\
(0.38)\end{array}$ & $\begin{array}{c}-0.04 \\
(0.30)\end{array}$ & $\begin{array}{c}0.19 \\
(0.49)\end{array}$ & $\begin{array}{c}-0.26 \\
(0.38)\end{array}$ & $\begin{array}{l}-0.01 \\
(0.47)\end{array}$ & $\begin{array}{c}-0.44 \\
(0.34)\end{array}$ \\
\hline \multirow[t]{2}{*}{ AngDut2 } & $1273-1991$ & $\begin{array}{c}0.39 \\
(0.43)\end{array}$ & $\begin{array}{c}0.14 \\
(0.32)\end{array}$ & $\begin{array}{c}-0.03 \\
(0.34)\end{array}$ & $\begin{array}{c}0.06 \\
(0.42)\end{array}$ & $\begin{array}{c}0.12 \\
(0.37)\end{array}$ & $\begin{array}{c}0.18 \\
(0.34)\end{array}$ \\
\hline & $1600-99$ & $\begin{array}{c}0.33 \\
(0.43)\end{array}$ & $\begin{array}{c}0.10 \\
(0.23)\end{array}$ & $\begin{array}{c}-0.09 \\
(0.26)\end{array}$ & $\begin{array}{c}-0.02 \\
(0.40)\end{array}$ & $\begin{array}{c}0.06 \\
(0.41)\end{array}$ & $\begin{array}{c}0.12 \\
(0.26)\end{array}$ \\
\hline \multirow[t]{2}{*}{ AngDut3 } & $1273-1991$ & $\begin{array}{c}0.06 \\
(0.39)\end{array}$ & $\begin{array}{c}0.10 \\
(0.30)\end{array}$ & $\begin{array}{c}-0.10 \\
(0.31)\end{array}$ & $\begin{array}{c}-0.06 \\
(0.35)\end{array}$ & $\begin{array}{c}0.15 \\
(0.34)\end{array}$ & $\begin{array}{c}0.00 \\
(0.30)\end{array}$ \\
\hline & $1600-99$ & $\begin{array}{c}-0.18 \\
(0.38)\end{array}$ & $\begin{array}{c}0.04 \\
(0.22)\end{array}$ & $\begin{array}{l}-0.10 \\
(0.27)\end{array}$ & $\begin{array}{c}-0.14 \\
(0.34)\end{array}$ & $\begin{array}{c}0.02 \\
(0.41)\end{array}$ & $\begin{array}{c}-0.01 \\
(0.25)\end{array}$ \\
\hline \multirow[t]{2}{*}{ SpanSucc } & $1273-1991$ & $\begin{array}{c}0.02 \\
(0.24)\end{array}$ & $\begin{array}{c}0.06 \\
(0.21)\end{array}$ & $\begin{array}{c}0.29 \\
(0.18)\end{array}$ & $\begin{array}{c}0.14 \\
(0.20)\end{array}$ & $\begin{array}{c}0.05 \\
(0.19)\end{array}$ & $\begin{array}{c}0.03 \\
(0.19)\end{array}$ \\
\hline & $1700-99$ & $\begin{array}{c}1.05 \\
(1.00)\end{array}$ & $\begin{array}{c}-0.42 \\
(0.51)\end{array}$ & $\begin{array}{l}-0.02 \\
(0.61)\end{array}$ & $\begin{array}{c}0.08 \\
(1.70)\end{array}$ & $\begin{array}{c}-0.27 \\
(1.95)\end{array}$ & $\begin{array}{c}0.14 \\
(0.54)\end{array}$ \\
\hline \multirow[t]{2}{*}{ AngDut4 } & $1273-1991$ & $\begin{array}{c}-0.31 \\
(0.23)\end{array}$ & $\begin{array}{c}0.06 \\
(0.25)\end{array}$ & $\begin{array}{c}0.09 \\
(0.22)\end{array}$ & $\begin{array}{c}-0.00 \\
(0.19)\end{array}$ & $\begin{array}{c}0.24 \\
(0.22)\end{array}$ & $\begin{array}{c}0.11 \\
(0.24)\end{array}$ \\
\hline & $1700-99$ & $\begin{array}{c}-0.13 \\
(0.30)\end{array}$ & $\begin{array}{c}-0.11 \\
(0.19)\end{array}$ & $\begin{array}{c}-0.06 \\
(0.27)\end{array}$ & $\begin{array}{c}-0.02 \\
(0.21)\end{array}$ & $\begin{array}{c}0.28 \\
(0.25)\end{array}$ & $\begin{array}{c}0.03 \\
(0.19)\end{array}$ \\
\hline \multirow[t]{2}{*}{ FrenRev } & $1273-1991$ & $\begin{array}{c}-0.02 \\
(0.29)\end{array}$ & $\begin{array}{c}0.15 \\
(0.30)\end{array}$ & $\begin{array}{c}0.11 \\
(0.28)\end{array}$ & $\begin{array}{c}0.01 \\
(0.25)\end{array}$ & $\begin{array}{c}0.19 \\
(0.29)\end{array}$ & $\begin{array}{c}0.03 \\
(0.30)\end{array}$ \\
\hline & $1700-99$ & $\begin{array}{c}-0.00 \\
(0.34)\end{array}$ & $\begin{array}{c}0.12 \\
(0.24)\end{array}$ & $\begin{array}{c}0.01 \\
(0.32)\end{array}$ & $\begin{array}{c}0.01 \\
(0.26)\end{array}$ & $\begin{array}{c}0.30 \\
(0.32)\end{array}$ & $\begin{array}{c}0.11 \\
(0.25)\end{array}$ \\
\hline
\end{tabular}


continued from previous page

\begin{tabular}{|c|c|c|c|c|c|c|c|}
\hline War & Period & Barley & Butter & Cheese & Oats & Peas & Wheat \\
\hline \multirow[t]{2}{*}{ NapWar } & 1273-1991 & $\begin{array}{c}0.18 \\
(0.25)\end{array}$ & $\begin{array}{c}0.03 \\
(0.28)\end{array}$ & $\begin{array}{c}0.28 \\
(0.25)\end{array}$ & $\begin{array}{c}0.21 \\
(0.21)\end{array}$ & $\begin{array}{c}-0.24 \\
(0.25)\end{array}$ & $\begin{array}{c}0.04 \\
(0.27)\end{array}$ \\
\hline & $1800-99$ & $\begin{array}{c}0.51 \\
(0.52)\end{array}$ & $\begin{array}{c}0.17 \\
(0.46)\end{array}$ & $\begin{array}{c}0.52 \\
(0.48)\end{array}$ & $\begin{array}{c}0.25 \\
(0.62)\end{array}$ & $\begin{array}{c}0.84 \\
(0.68)\end{array}$ & $\begin{array}{c}0.49 \\
(0.57)\end{array}$ \\
\hline \multirow[t]{2}{*}{ WWI } & $1273-1991$ & $\begin{array}{c}-0.09 \\
(0.19)\end{array}$ & $\begin{array}{c}-0.22 \\
(0.22)\end{array}$ & $\begin{array}{c}-0.08 \\
(0.19)\end{array}$ & $\begin{array}{c}-0.15 \\
(0.16)\end{array}$ & $\begin{array}{c}0.43 \\
(0.23)\end{array}$ & $\begin{array}{c}-0.14 \\
(0.20)\end{array}$ \\
\hline & $1990-91$ & $\begin{array}{c}0.02 \\
(0.38)\end{array}$ & $\begin{array}{c}-0.02 \\
(0.37)\end{array}$ & $\begin{array}{c}0.17 \\
(0.30)\end{array}$ & $\begin{array}{c}-0.09 \\
(0.28)\end{array}$ & $\begin{array}{c}0.35 \\
(0.51)\end{array}$ & $\begin{array}{c}-0.07 \\
(0.38)\end{array}$ \\
\hline \multirow[t]{2}{*}{ WWII } & $1273-1991$ & $\begin{array}{c}-0.12 \\
(0.20)\end{array}$ & $\begin{array}{c}-0.11 \\
(0.24)\end{array}$ & $\begin{array}{l}-0.12 \\
(0.24)\end{array}$ & $\begin{array}{c}-0.12 \\
(0.16)\end{array}$ & $\begin{array}{c}-0.16 \\
(0.24)\end{array}$ & $\begin{array}{c}0.04 \\
(0.21)\end{array}$ \\
\hline & $1990-91$ & $\begin{array}{c}0.11 \\
(0.39)\end{array}$ & $\begin{array}{c}-0.03 \\
(0.36)\end{array}$ & $\begin{array}{c}-0.02 \\
(0.33)\end{array}$ & $\begin{array}{c}-0.20 \\
(0.27)\end{array}$ & $\begin{array}{c}-0.03 \\
(0.29)\end{array}$ & $\begin{array}{c}-0.19 \\
(0.36)\end{array}$ \\
\hline
\end{tabular}

Average regression coefficient across the six specifications run for each series and time period: (a) constant; (b) constant transitory war dummy and transitory plague dummy; (c) constant, transitory war dummy, transitory plague dummy, and permanent war and plague dummies; and (d) specifications (a) through (c) run with a time trend. The variable "Wars" is a minus one-zero-one dummy as described in the accompanying text. The remaining variables are zero-one dummies that take the value 1 in all years subsequent to the outbreak of that war. The war years are as follows: Roses: 1455-1485; Dutind: 1572-1609; EngCiv: 1642-1649; AngDut1: 1652-1654; AngDut2: 1665-1667; AngDut3: 1672-1674; SpanSucc: 1702-1713; AngDut4: 1780-1784; FrenRev: 1793-1802; NapWar: 1803-1815; WW1: 1914-1918; WW2: 1939-1945. 
Table A.2: Relative English/Dutch commodity prices in log grams of silver, 1273-1991: Average coefficient on plague dummies.

\begin{tabular}{|c|c|c|c|c|c|c|c|}
\hline Plague & Period & Barley & Butter & Cheese & Oats & Peas & Wheat \\
\hline \multirow[t]{11}{*}{ Plagues } & $1273-1991$ & $\begin{array}{c}0.12 \\
(0.19)\end{array}$ & $\begin{array}{c}0.44 \\
(0.50)\end{array}$ & $\begin{array}{c}-0.05 \\
(0.79)\end{array}$ & $\begin{array}{c}-0.04 \\
(0.18)\end{array}$ & $\begin{array}{c}-0.09 \\
(0.24)\end{array}$ & $\begin{array}{c}0.30 \\
(0.18)\end{array}$ \\
\hline & $1273-1399$ & . & . & . & 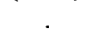 & . & 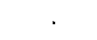 \\
\hline & $1400-99$ & $\begin{array}{c}0.34 \\
(0.33)\end{array}$ & $\dot{.}$ & . & $\begin{array}{c}-0.26 \\
(0.37)\end{array}$ & $\begin{array}{c}0.14 \\
(0.60)\end{array}$ & $\begin{array}{c}0.38 \\
(0.34)\end{array}$ \\
\hline & $1500-99$ & $\begin{array}{c}0.04 \\
(0.22)\end{array}$ & . & . & $\begin{array}{c}0.16 \\
(0.19)\end{array}$ & $\begin{array}{c}-0.04 \\
(0.27)\end{array}$ & $\begin{array}{c}0.31 \\
(0.23)\end{array}$ \\
\hline & $1600-99$ & . & . & & 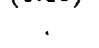 & . & . \\
\hline & & . & . & . & . & . & . \\
\hline & $1700-99$ & . & . & . & . & . & . \\
\hline & & . & $\cdot$ & . & . & . & . \\
\hline & $1800-99$ & . & . & . & . & . & . \\
\hline & $1900-91$ & . & . & . & . & . & . \\
\hline & $1900-91$ & 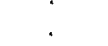 & . & . & . & . & . \\
\hline \multirow[t]{3}{*}{ ENGPL1 } & $1273-1991$ & . & . & . & . & . & . \\
\hline & & . & . & . & . & . & . \\
\hline & $12 \sqrt{3}-1399$ & . & . & . & . & . & . \\
\hline \multirow[t]{3}{*}{ ENGPL2 } & $1273-1991$ & . & . & . & . & . & . \\
\hline & & . & . & . & . & . & . \\
\hline & $1273-1399$ & . & . & . & . & . & . \\
\hline \multirow{4}{*}{ ENPL3 } & & 0.15 & $\cdot$ & · & -0.00 & -3.65 & . \\
\hline & $1273-1991$ & $\begin{array}{c}0.15 \\
(1.42)\end{array}$ & . & . & $\begin{array}{l}-0.00 \\
(0.59)\end{array}$ & $\begin{array}{l}-3.65 \\
(2.82)\end{array}$ & . \\
\hline & $1273-1399$ & 1.40 & . & . & 0.02 & 9.18 & . \\
\hline & & $(2.61)$ & . & . & $(0.59)$ & (3.64) & . \\
\hline \multirow[t]{3}{*}{ ENPL4 } & $1273-1991$ & -0.22 & & . & -0.03 & -0.34 & 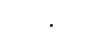 \\
\hline & $1273-1399$ & $(0.37)$ & . & . & $(0.27)$ & $(0.46)$ & . \\
\hline & $1273-1399$ & $\begin{array}{c}-0.10 \\
(0.29)\end{array}$ & . & . & $\begin{array}{c}0.09 \\
(0.32)\end{array}$ & $\begin{array}{c}-0.16 \\
(0.31)\end{array}$ & . \\
\hline \multirow[t]{3}{*}{ ENPL5 } & $1273-1991$ & . & . & . & . & . & . \\
\hline & & . & . & . & . & . & 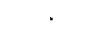 \\
\hline & $1273-1399$ & . & $\cdot$ & . & . & . & . \\
\hline \multirow[t]{3}{*}{ ENPL6 } & 1273-1991 & -0.09 & . & . & -0.22 & 0.35 & 0.03 \\
\hline & & $(0.27)$ & $\cdot$ & . & $(0.23)$ & $(0.55)$ & $(0.41)$ \\
\hline & $1400-99$ & . & . & . & . & . & 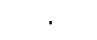 \\
\hline \multirow[t]{4}{*}{ ENPL7 } & $1273-1991$ & -0.42 & . & . & -0.20 & -0.58 & -0.38 \\
\hline & & $(0.29)$ & . & . & $(0.25)$ & $(0.41)$ & $(0.31)$ \\
\hline & $1400-99$ & -0.37 & . & . & -0.11 & -0.65 & -0.32 \\
\hline & & $(0.28)$ & . & . & $(0.26)$ & $(0.41)$ & $(0.34)$ \\
\hline \multirow[t]{4}{*}{ ENPL8 } & $1273-1991$ & 0.22 & . & . & 0.18 & 0.54 & 0.55 \\
\hline & & $(0.32)$ & . & . & $(0.28)$ & $(0.40)$ & $(0.33)$ \\
\hline & $1400-99$ & 0.33 & . & & 0.22 & 0.58 & 0.65 \\
\hline & & $(0.29)$ & . & . & $(0.27)$ & $(0.37)$ & $(0.35)$ \\
\hline \multirow[t]{4}{*}{ DTPL1 } & 1273-1991 & 0.02 & . & . & -0.32 & -0.24 & -0.17 \\
\hline & & $(0.29)$ & . & . & $(0.25)$ & $(0.27)$ & $(0.30)$ \\
\hline & $1400-99$ & 0.01 & . & . & -0.22 & -0.27 & -0.11 \\
\hline & & $(0.27)$ & . & . & $(0.25)$ & $(0.26)$ & $(0.32)$ \\
\hline
\end{tabular}


continued from previous page

\begin{tabular}{|c|c|c|c|c|c|c|c|}
\hline Plague & Period & Barley & Butter & Cheese & Oats & Peas & Wheat \\
\hline \multirow[t]{2}{*}{ DTPL2 } & $1273-1991$ & $\begin{array}{c}0.16 \\
(0.35)\end{array}$ & . & . & $\begin{array}{c}0.30 \\
(0.30)\end{array}$ & $\begin{array}{l}-0.16 \\
(0.34)\end{array}$ & $\begin{array}{c}0.36 \\
(0.36)\end{array}$ \\
\hline & $1400-99$ & $\begin{array}{c}0.19 \\
(0.31)\end{array}$ & . & . & $\begin{array}{c}0.37 \\
(0.29)\end{array}$ & $\begin{array}{c}-0.23 \\
(0.30)\end{array}$ & $\begin{array}{c}0.42 \\
(0.36)\end{array}$ \\
\hline \multirow[t]{2}{*}{ ENPL9 } & $1273-1991$ & $\begin{array}{c}0.22 \\
(0.43)\end{array}$ & . & . & $\begin{array}{c}0.07 \\
(0.39)\end{array}$ & $\begin{array}{c}0.42 \\
(0.46)\end{array}$ & $\begin{array}{c}0.23 \\
(0.41)\end{array}$ \\
\hline & $1400-99$ & $\begin{array}{c}0.30 \\
(0.40)\end{array}$ & . & . & $\begin{array}{c}0.17 \\
(0.40)\end{array}$ & $\begin{array}{c}0.54 \\
(0.43)\end{array}$ & $\begin{array}{c}0.31 \\
(0.44)\end{array}$ \\
\hline \multirow[t]{2}{*}{ DTPL3 } & $1273-1991$ & $\begin{array}{l}-0.02 \\
(0.27)\end{array}$ & . & . & $\begin{array}{c}-0.12 \\
(0.23)\end{array}$ & $\begin{array}{c}-0.05 \\
(0.27)\end{array}$ & $\begin{array}{c}-0.10 \\
(0.29)\end{array}$ \\
\hline & $1400-99$ & $\begin{array}{c}0.02 \\
(0.27)\end{array}$ & . & . & $\begin{array}{c}-0.03 \\
(0.25)\end{array}$ & $\begin{array}{c}-0.12 \\
(0.28)\end{array}$ & $\begin{array}{c}-0.01 \\
(0.32)\end{array}$ \\
\hline \multirow[t]{2}{*}{ ENPL10 } & $1273-1991$ & $\begin{array}{c}-0.22 \\
(0.31)\end{array}$ & . & . & $\begin{array}{c}-0.28 \\
(0.27)\end{array}$ & $\begin{array}{c}-0.15 \\
(0.34)\end{array}$ & $\begin{array}{c}-0.29 \\
(0.32)\end{array}$ \\
\hline & $1400-99$ & $\begin{array}{l}-0.11 \\
(0.47)\end{array}$ & . & . & $\begin{array}{c}0.13 \\
(0.51)\end{array}$ & $\begin{array}{c}0.07 \\
(0.59)\end{array}$ & $\begin{array}{c}0.01 \\
(0.49)\end{array}$ \\
\hline \multirow[t]{2}{*}{ DTPL4 } & $1273-1991$ & $\begin{array}{c}0.35 \\
(0.35)\end{array}$ & . & . & $\begin{array}{c}0.59 \\
(0.31)\end{array}$ & $\begin{array}{c}0.19 \\
(0.44)\end{array}$ & $\begin{array}{c}0.40 \\
(0.36)\end{array}$ \\
\hline & $1400-99$ & $\begin{array}{c}0.43 \\
(0.33)\end{array}$ & . & . & $\begin{array}{c}0.57 \\
(0.31)\end{array}$ & $\begin{array}{c}0.11 \\
(0.42)\end{array}$ & $\begin{array}{c}0.55 \\
(0.39)\end{array}$ \\
\hline \multirow[t]{2}{*}{ DTPL5 } & 1273-1991 & $\begin{array}{c}-0.02 \\
(0.33)\end{array}$ & . & . & $\begin{array}{c}-0.27 \\
(0.29)\end{array}$ & $\begin{array}{c}0.24 \\
(0.42)\end{array}$ & $\begin{array}{c}-0.07 \\
(0.34)\end{array}$ \\
\hline & $1400-99$ & $\begin{array}{c}0.11 \\
(0.50)\end{array}$ & . & . & $\begin{array}{c}0.01 \\
(0.53)\end{array}$ & . & $\begin{array}{c}0.13 \\
(0.52)\end{array}$ \\
\hline \multirow[t]{2}{*}{ ENDTPL1 } & $1273-1991$ & $\begin{array}{c}-0.21 \\
(0.28)\end{array}$ & . & . & $\begin{array}{c}-0.17 \\
(0.24)\end{array}$ & $\begin{array}{l}-0.15 \\
(0.32)\end{array}$ & $\begin{array}{c}-0.09 \\
(0.29)\end{array}$ \\
\hline & $1500-99$ & $\begin{array}{l}-0.12 \\
(0.27)\end{array}$ & . & . & $\begin{array}{c}-0.14 \\
(0.23)\end{array}$ & $\begin{array}{c}0.10 \\
(0.33)\end{array}$ & $\begin{array}{c}0.21 \\
(0.29)\end{array}$ \\
\hline \multirow[t]{2}{*}{ ENPL11 } & $1273-1991$ & $\begin{array}{c}0.24 \\
(0.32)\end{array}$ & . & . & $\begin{array}{c}0.28 \\
(0.28)\end{array}$ & $\begin{array}{c}-0.02 \\
(0.37)\end{array}$ & $\begin{array}{c}0.34 \\
(0.33)\end{array}$ \\
\hline & $1500-99$ & $\begin{array}{c}0.12 \\
(0.33)\end{array}$ & . & . & $\begin{array}{c}0.37 \\
(0.27)\end{array}$ & $\begin{array}{c}0.18 \\
(0.43)\end{array}$ & $\begin{array}{c}0.54 \\
(0.36)\end{array}$ \\
\hline \multirow[t]{2}{*}{ ENPL 12} & $1273-1991$ & $\begin{array}{c}-0.16 \\
(0.35)\end{array}$ & . & . & $\begin{array}{c}-0.02 \\
(0.31)\end{array}$ & $\begin{array}{c}-0.32 \\
(0.58)\end{array}$ & $\begin{array}{c}-0.48 \\
(0.35)\end{array}$ \\
\hline & $1500-99$ & $\begin{array}{l}-0.04 \\
(0.30)\end{array}$ & . & . & $\begin{array}{c}-0.22 \\
(0.24)\end{array}$ & $\begin{array}{c}-0.13 \\
(0.61)\end{array}$ & $\begin{array}{c}-0.33 \\
(0.33)\end{array}$ \\
\hline \multirow[t]{2}{*}{ ENPL13 } & $1273-1991$ & $\begin{array}{c}-0.03 \\
(0.40)\end{array}$ & e & . & $\begin{array}{l}-0.06 \\
(0.32)\end{array}$ & $\begin{array}{c}0.46 \\
(0.67)\end{array}$ & $\begin{array}{c}0.04 \\
(0.37)\end{array}$ \\
\hline & $1500-99$ & $\begin{array}{c}-0.17 \\
(0.35)\end{array}$ & . & . & $\begin{array}{c}-0.06 \\
(0.25)\end{array}$ & $\begin{array}{c}0.50 \\
(0.75)\end{array}$ & $\begin{array}{c}0.14 \\
(0.34)\end{array}$ \\
\hline \multirow[t]{2}{*}{ ENPL14 } & $1273-1991$ & $\begin{array}{c}0.30 \\
(0.41)\end{array}$ & . & . & $\begin{array}{c}0.28 \\
(0.32)\end{array}$ & $\begin{array}{l}-0.41 \\
(0.60)\end{array}$ & $\begin{array}{c}0.47 \\
(0.36)\end{array}$ \\
\hline & $1500-99$ & $\begin{array}{c}0.40 \\
(0.36)\end{array}$ & . & . & $\begin{array}{c}0.24 \\
(0.24)\end{array}$ & $\begin{array}{l}-0.14 \\
(0.62)\end{array}$ & $\begin{array}{c}0.55 \\
(0.33)\end{array}$ \\
\hline \multirow[t]{2}{*}{ ENDTPL2 } & $1273-1991$ & $\begin{array}{l}-0.36 \\
(0.37)\end{array}$ & . & . & $\begin{array}{c}-0.07 \\
(0.31)\end{array}$ & $\begin{array}{l}-0.20 \\
(0.54)\end{array}$ & $\begin{array}{l}-0.33 \\
(0.36)\end{array}$ \\
\hline & $1500-99$ & $\begin{array}{c}-0.29 \\
(0.32)\end{array}$ & . & . & $\begin{array}{c}0.00 \\
(0.25)\end{array}$ & $\begin{array}{c}-0.14 \\
(0.50)\end{array}$ & $\begin{array}{c}-0.04 \\
(0.34)\end{array}$ \\
\hline \multirow[t]{2}{*}{ ENPL15 } & $1273-1991$ & $\begin{array}{c}0.00 \\
(0.35)\end{array}$ & . & . & $\begin{array}{c}-0.03 \\
(0.31)\end{array}$ & $\begin{array}{c}0.16 \\
(0.47)\end{array}$ & $\begin{array}{c}-0.05 \\
(0.36)\end{array}$ \\
\hline & $1500-99$ & $\begin{array}{l}-0.09 \\
(0.28)\end{array}$ & 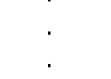 & . & $\begin{array}{l}-0.15 \\
(0.23)\end{array}$ & $\begin{array}{c}0.32 \\
(0.44)\end{array}$ & $\begin{array}{l}-0.03 \\
(0.32)\end{array}$ \\
\hline
\end{tabular}


continued from previous page

\begin{tabular}{|c|c|c|c|c|c|c|c|}
\hline Plague & Period & Barley & Butter & Cheese & Oats & Peas & Wheat \\
\hline \multirow[t]{2}{*}{ DTPL6 } & 1273-1991 & $\begin{array}{c}0.19 \\
(0.45)\end{array}$ & $\begin{array}{c}0.53 \\
(1.39)\end{array}$ & $\begin{array}{c}-1.87 \\
(3.35)\end{array}$ & $\begin{array}{c}0.18 \\
(0.40)\end{array}$ & $\begin{array}{l}-0.00 \\
(0.47)\end{array}$ & $\begin{array}{c}0.20 \\
(0.42)\end{array}$ \\
\hline & $1500-99$ & $\begin{array}{c}0.29 \\
(0.42)\end{array}$ & . & . & $\begin{array}{c}0.34 \\
(0.33)\end{array}$ & $\begin{array}{c}0.19 \\
(0.43)\end{array}$ & $\begin{array}{c}0.37 \\
(0.43)\end{array}$ \\
\hline \multirow[t]{2}{*}{ DTPL7 } & $1273-1991$ & $\begin{array}{c}0.11 \\
(0.35)\end{array}$ & $\begin{array}{c}0.45 \\
(0.41)\end{array}$ & $\begin{array}{c}0.17 \\
(0.46)\end{array}$ & $\begin{array}{c}0.45 \\
(0.28)\end{array}$ & $\begin{array}{c}0.48 \\
(0.35)\end{array}$ & $\begin{array}{c}0.18 \\
(0.33)\end{array}$ \\
\hline & $1500-99$ & $\begin{array}{c}0.16 \\
(0.29)\end{array}$ & & 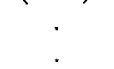 & $\begin{array}{c}0.34 \\
(0.22)\end{array}$ & $\begin{array}{c}0.63 \\
(0.32)\end{array}$ & $\begin{array}{c}0.35 \\
(0.30)\end{array}$ \\
\hline \multirow[t]{2}{*}{ ENPL16 } & $1273-1991$ & $\begin{array}{c}0.27 \\
(0.43)\end{array}$ & $\begin{array}{c}-0.06 \\
(0.35)\end{array}$ & $\begin{array}{c}0.51 \\
(0.49)\end{array}$ & $\begin{array}{c}0.05 \\
(\mathbf{0 . 3 3})\end{array}$ & $\begin{array}{c}0.18 \\
(0.43)\end{array}$ & $\begin{array}{c}0.38 \\
(0.38)\end{array}$ \\
\hline & $1500-99$ & $\begin{array}{c}0.15 \\
(0.40)\end{array}$ & & . & $\begin{array}{c}0.05 \\
(0.26)\end{array}$ & $\begin{array}{c}0.31 \\
(0.39)\end{array}$ & $\begin{array}{c}0.52 \\
(0.35)\end{array}$ \\
\hline \multirow[t]{2}{*}{ ENDTPL3 } & $1273-1991$ & $\begin{array}{c}0.07 \\
(0.41)\end{array}$ & $\begin{array}{c}-0.00 \\
(0.33)\end{array}$ & $\begin{array}{c}-0.19 \\
(0.46)\end{array}$ & $\begin{array}{c}0.06 \\
(0.31)\end{array}$ & $\begin{array}{l}-0.61 \\
(0.38)\end{array}$ & $\begin{array}{c}-0.18 \\
(0.35)\end{array}$ \\
\hline & $1500-99$ & $\begin{array}{l}-0.01 \\
(0.45)\end{array}$ & . & . & $\begin{array}{l}-0.17 \\
(0.31)\end{array}$ & $\begin{array}{c}-0.55 \\
(0.42)\end{array}$ & $\begin{array}{c}-0.28 \\
(0.41)\end{array}$ \\
\hline \multirow[t]{2}{*}{ DTPL8 } & 1273-1991 & $\begin{array}{c}0.04 \\
(0.31)\end{array}$ & $\begin{array}{c}0.03 \\
(0.31)\end{array}$ & $\begin{array}{c}-0.38 \\
(0.37)\end{array}$ & $\begin{array}{c}0.11 \\
(0.28)\end{array}$ & $\begin{array}{c}-0.39 \\
(0.30)\end{array}$ & $\begin{array}{c}0.06 \\
(0.32)\end{array}$ \\
\hline & $1600-99$ & $\begin{array}{c}-0.09 \\
(0.28)\end{array}$ & $\begin{array}{c}-0.05 \\
(0.23)\end{array}$ & $\begin{array}{l}-0.21 \\
(0.36)\end{array}$ & $\begin{array}{c}0.04 \\
(0.27)\end{array}$ & $\begin{array}{l}-0.47 \\
(0.37)\end{array}$ & $\begin{array}{c}-0.04 \\
(0.27)\end{array}$ \\
\hline \multirow[t]{2}{*}{ ENDTPL4 } & 1273-1991 & $\begin{array}{c}-0.04 \\
(0.30)\end{array}$ & $\begin{array}{c}-0.04 \\
(0.31)\end{array}$ & $\begin{array}{c}-0.69 \\
(0.34)\end{array}$ & $\begin{array}{l}-0.19 \\
(0.27)\end{array}$ & $\begin{array}{c}0.22 \\
(0.29)\end{array}$ & $\begin{array}{c}-0.06 \\
(0.31)\end{array}$ \\
\hline & $1600-99$ & $\begin{array}{c}-0.18 \\
(0.28)\end{array}$ & $\begin{array}{c}-0.05 \\
(0.21)\end{array}$ & $\begin{array}{c}-1.00 \\
(0.28)\end{array}$ & $\begin{array}{c}-0.26 \\
(0.27)\end{array}$ & $\begin{array}{c}0.13 \\
(0.34)\end{array}$ & $\begin{array}{c}-0.14 \\
(0.25)\end{array}$ \\
\hline \multirow[t]{2}{*}{ DTPL9 } & $1273-1991$ & $\begin{array}{c}0.66 \\
(0.43)\end{array}$ & $\begin{array}{c}0.14 \\
(0.35)\end{array}$ & $\begin{array}{c}0.31 \\
(0.41)\end{array}$ & $\begin{array}{c}0.25 \\
(0.44)\end{array}$ & $\begin{array}{c}0.14 \\
(0.40)\end{array}$ & $\begin{array}{c}0.38 \\
(0.39)\end{array}$ \\
\hline & $1600-99$ & $\begin{array}{c}0.65 \\
(0.41)\end{array}$ & $\begin{array}{c}0.21 \\
(0.28)\end{array}$ & $\begin{array}{c}0.25 \\
(0.37)\end{array}$ & $\begin{array}{c}0.21 \\
(0.43)\end{array}$ & $\begin{array}{c}0.11 \\
(0.44)\end{array}$ & $\begin{array}{c}0.37 \\
(0.32)\end{array}$ \\
\hline \multirow[t]{3}{*}{ ENPL5 } & $1273-1991$ & $\begin{array}{c}0.20 \\
(0.29)\end{array}$ & . & . & $\begin{array}{c}0.40 \\
(0.24)\end{array}$ & $\begin{array}{c}-0.61 \\
(0.57)\end{array}$ & . \\
\hline & $1600-99$ & . & . & . & . & . & . \\
\hline & & & . & v & . & & . \\
\hline
\end{tabular}

Average regression coefficient across the six specifications run for each series and time period: (a) constant; (b) constant, transitory war dummy and transitory plague dummy; (c) constant, transitory war dummy, transitory plague dummy, and permanent war and plague dummies; and (d) specifications (a) through (c) run with a time trend. The variable "Plagues" is a minus one-zero-one dummy as described in the accompanying text. The remaining variables are zero-one dummies that take the value 1 in all years subsequent to the outbreak of that plague. The plague years and their associated names are as follows (ENPL denotes English plague, DTPL denotes Dutch plague, and ENDTPL denotes a plague that occurred in both countries): ENPL1: 1348,1349; ENPL2: 1361,1362; ENPL3: 1368,1369; ENPL4: 1375; ENPL5: 1390,1391; ENPL6: 1400; ENPL7: 1420; ENPL8: 1427; DTPL1: 1439; DTPL2: 1450; ENPL9: 1457,1458; DTPL3: 1467-1774; ENPL10: 1485; DTPL4: 1493; DTPL5: 1499; ENDTPL1: 1511-1521; ENPL11: 1526-1532; ENPL12; 1536,1537; ENPL13: 1543; ENPL14: 1548; ENDTPL2: 1557, 1558; ENPL15: 1563; DTPL6: 1574, 1575; DTPL7: 1585, 1586, 1587, 1588; ENPL16: 1593; ENDTPL3: 1597-1605; DTPL8: 1617; ENDTPL4: 1624-1632; DTPL9: 1655, 1656; ENDTPL5: 1664, 1665, 1666. 
Figure 1: English and Dutch commodity prices, 1273-1991 Data coverage

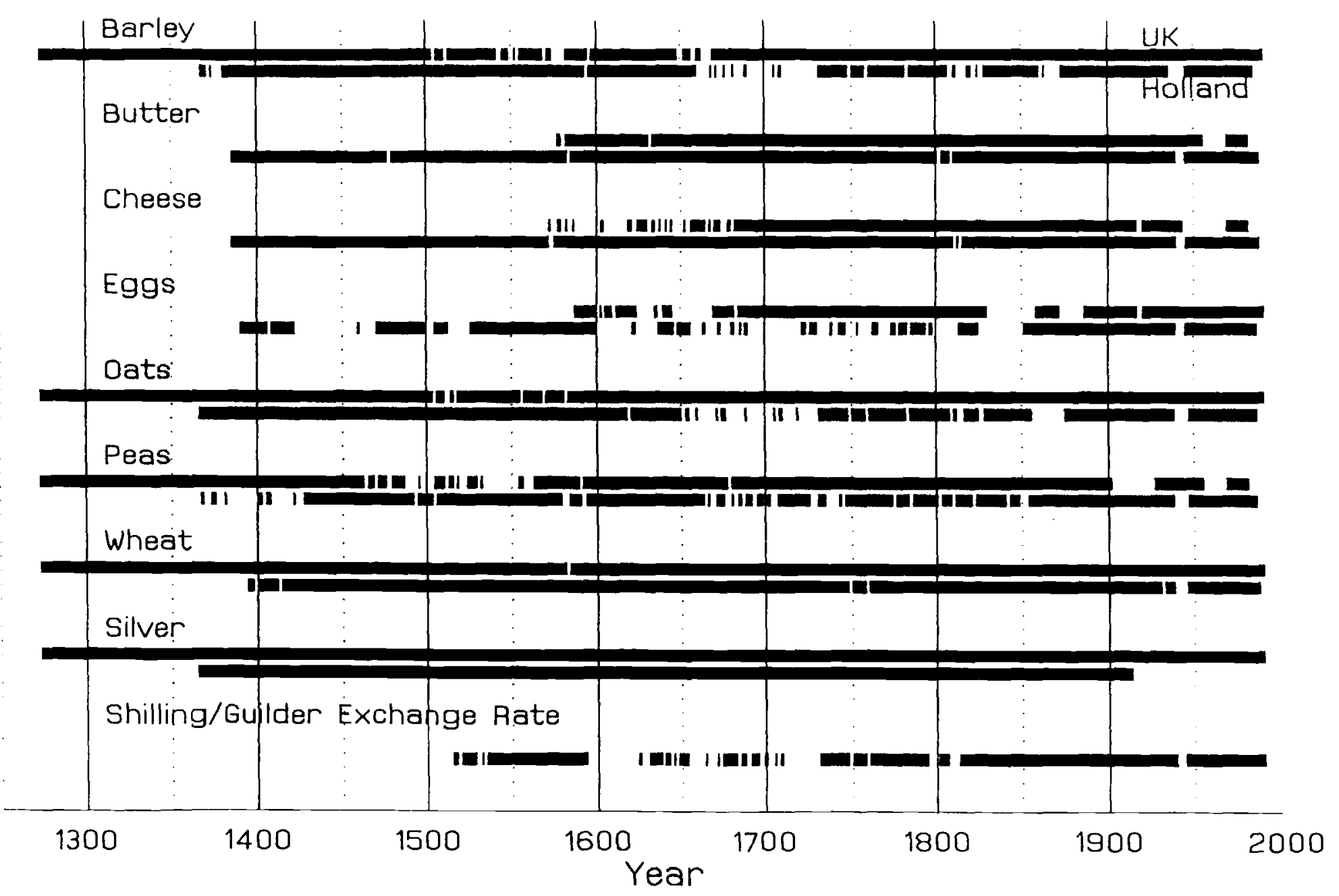


Figure 2: English barley, butter and oats, 1273-1991 Log price in grams of silver per unit

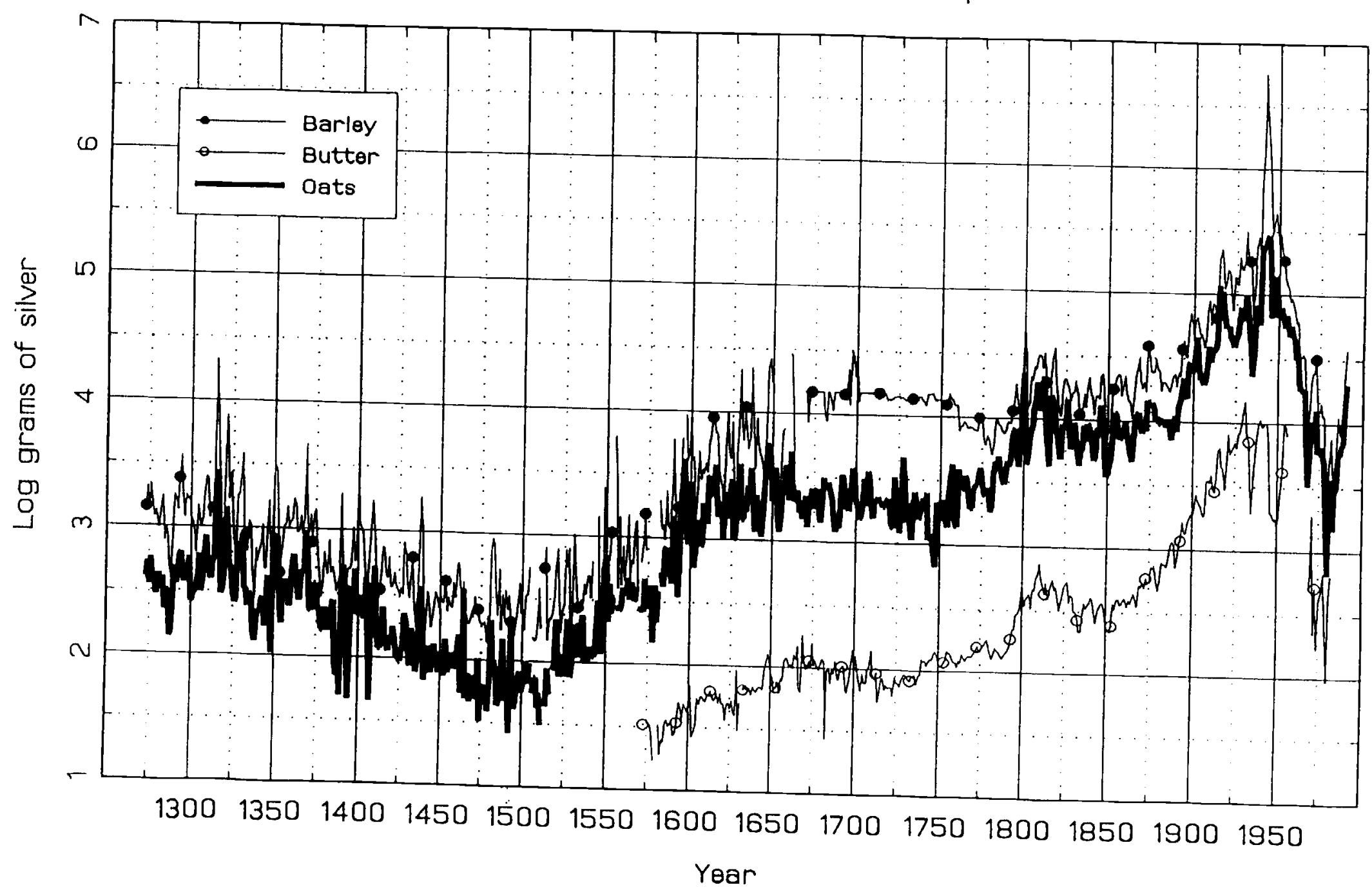




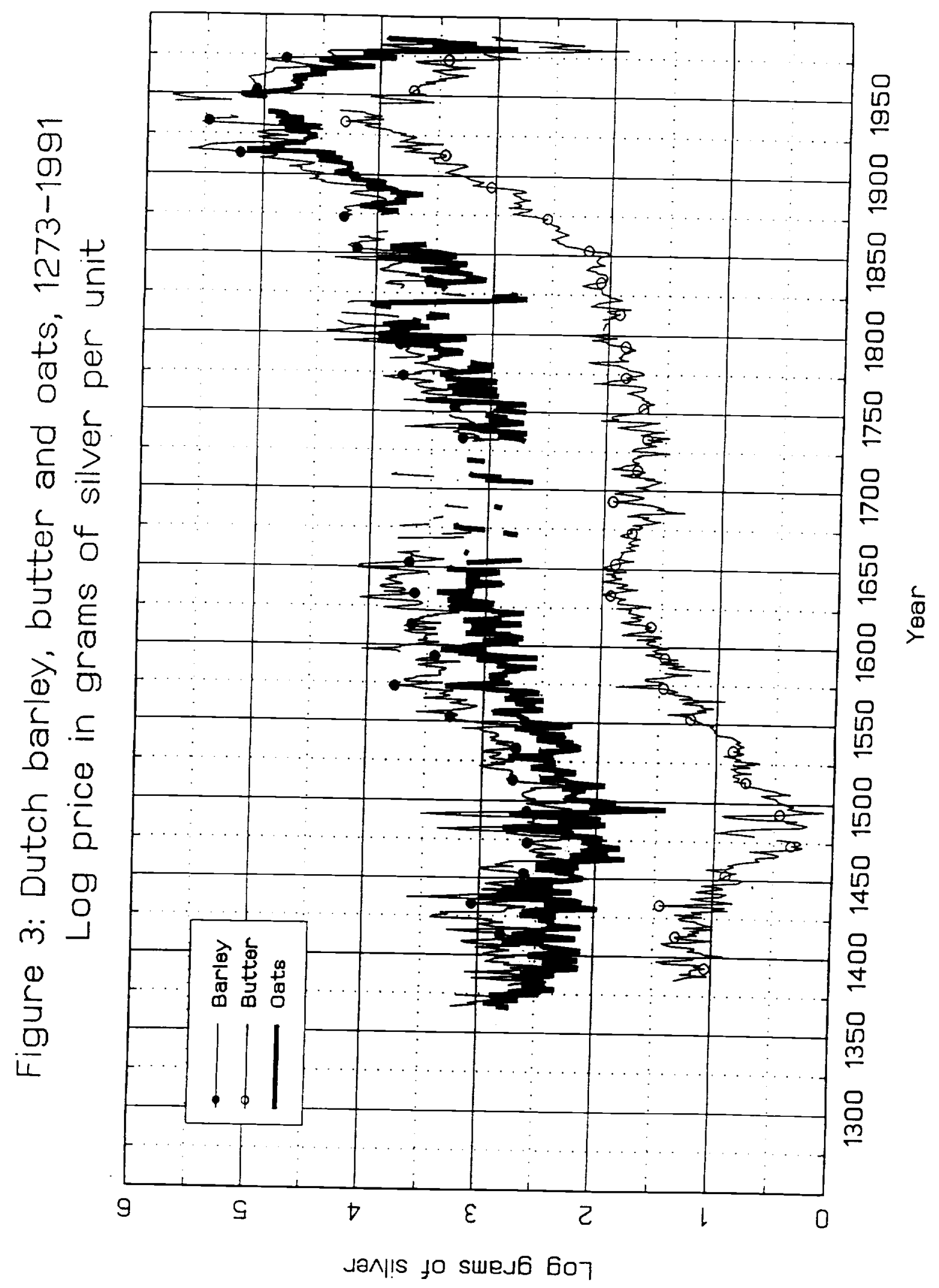




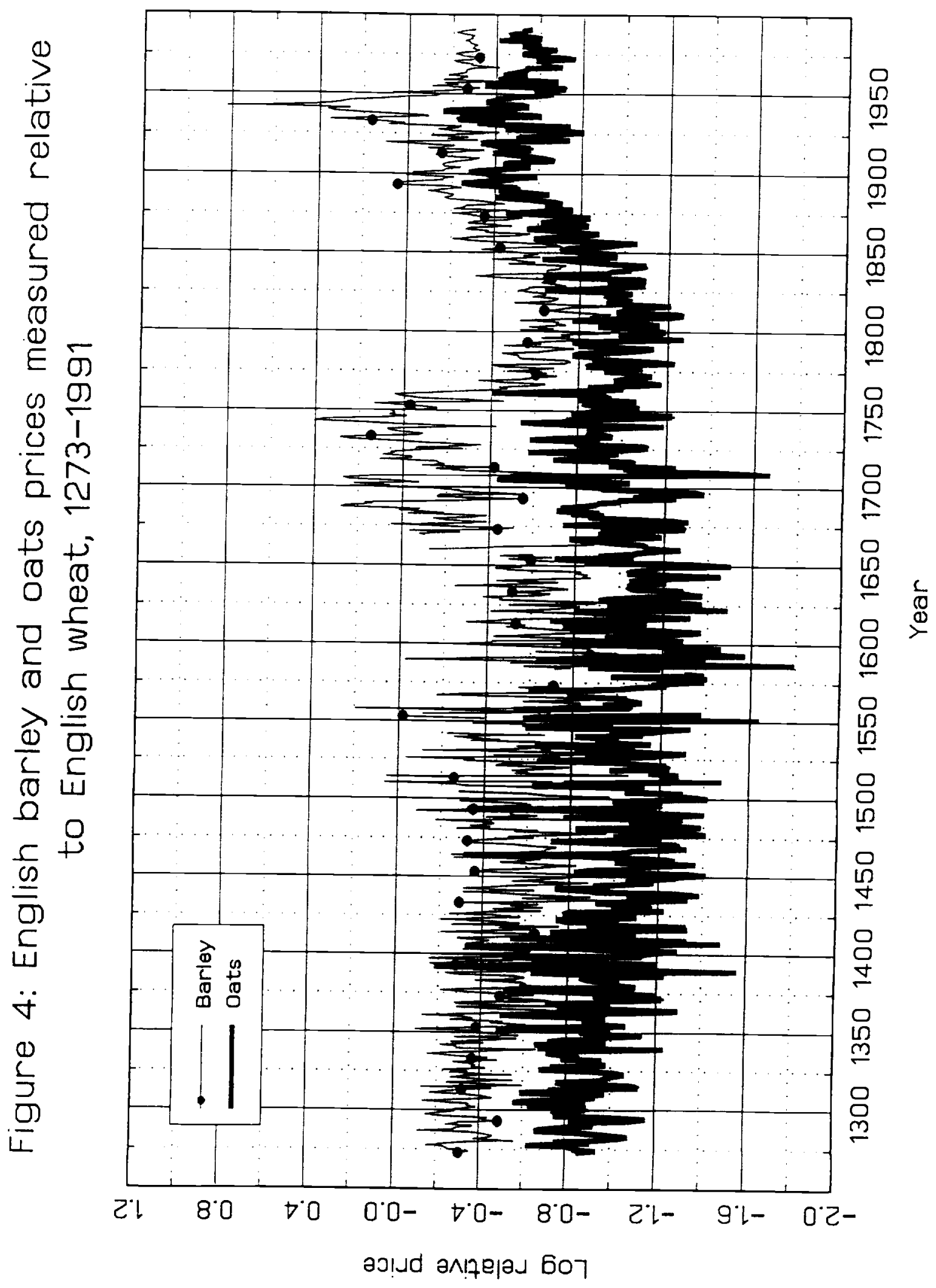




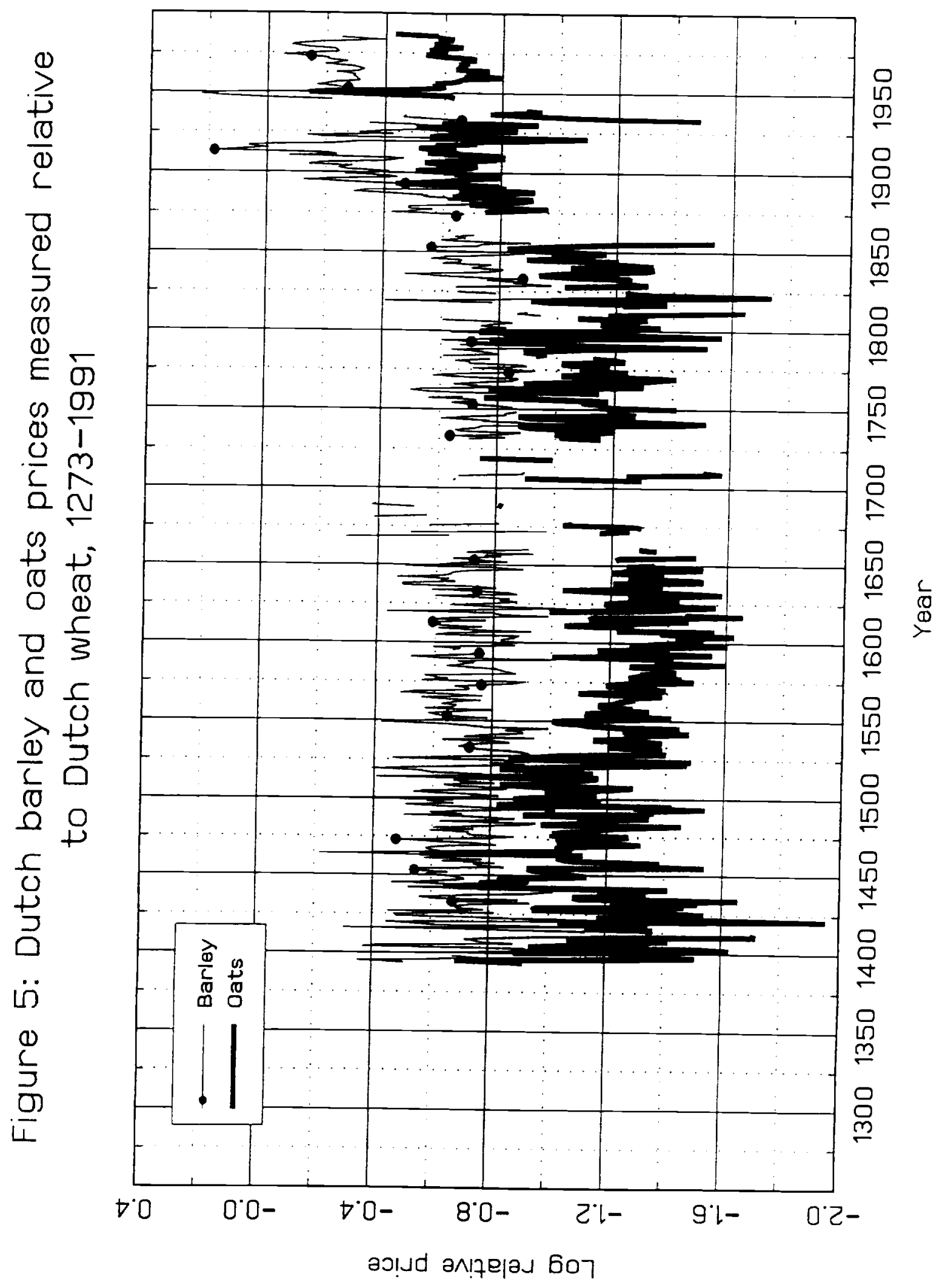




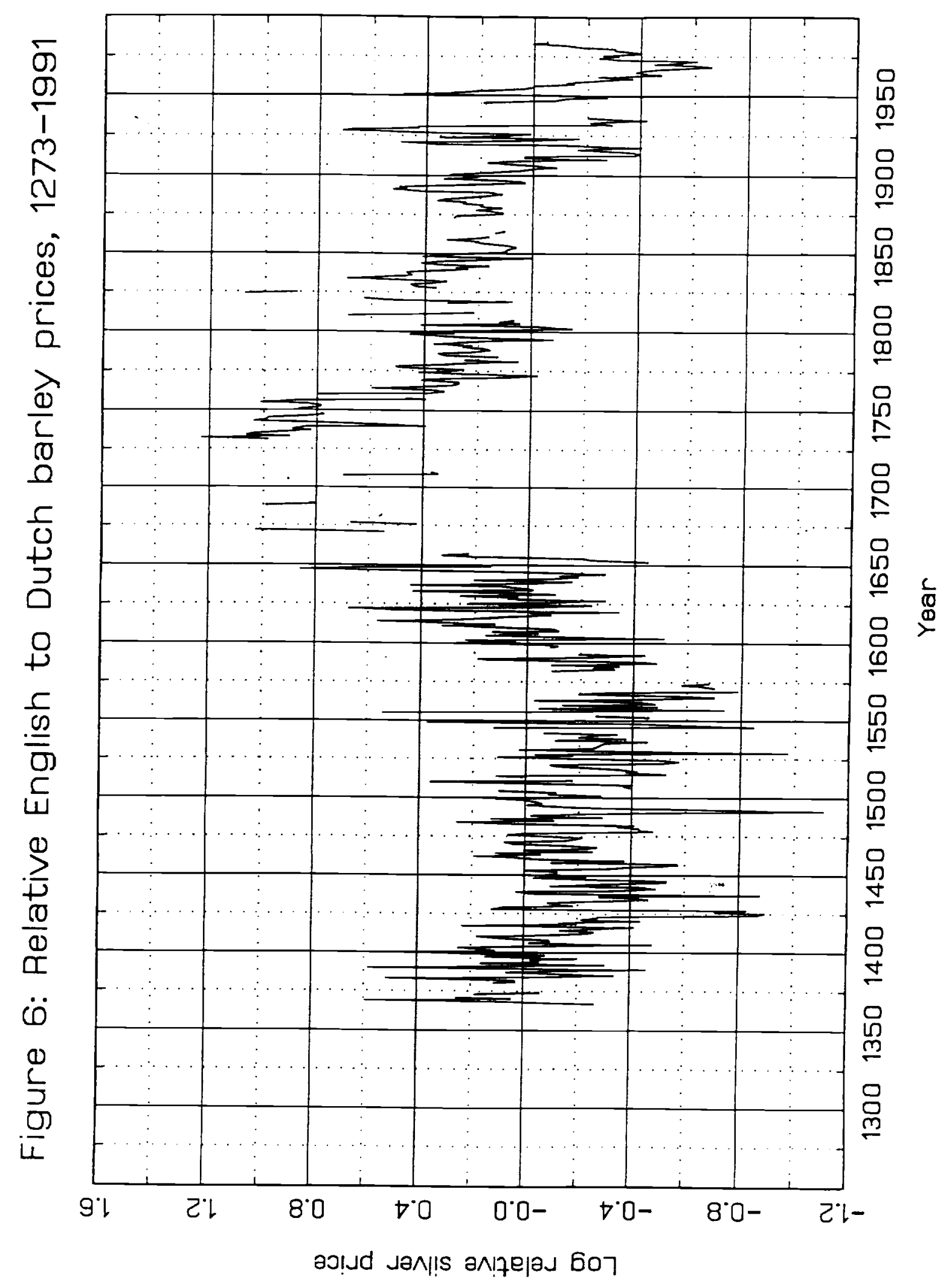


Figure 7: Relative English to Dutch oats prices, 1273-1991

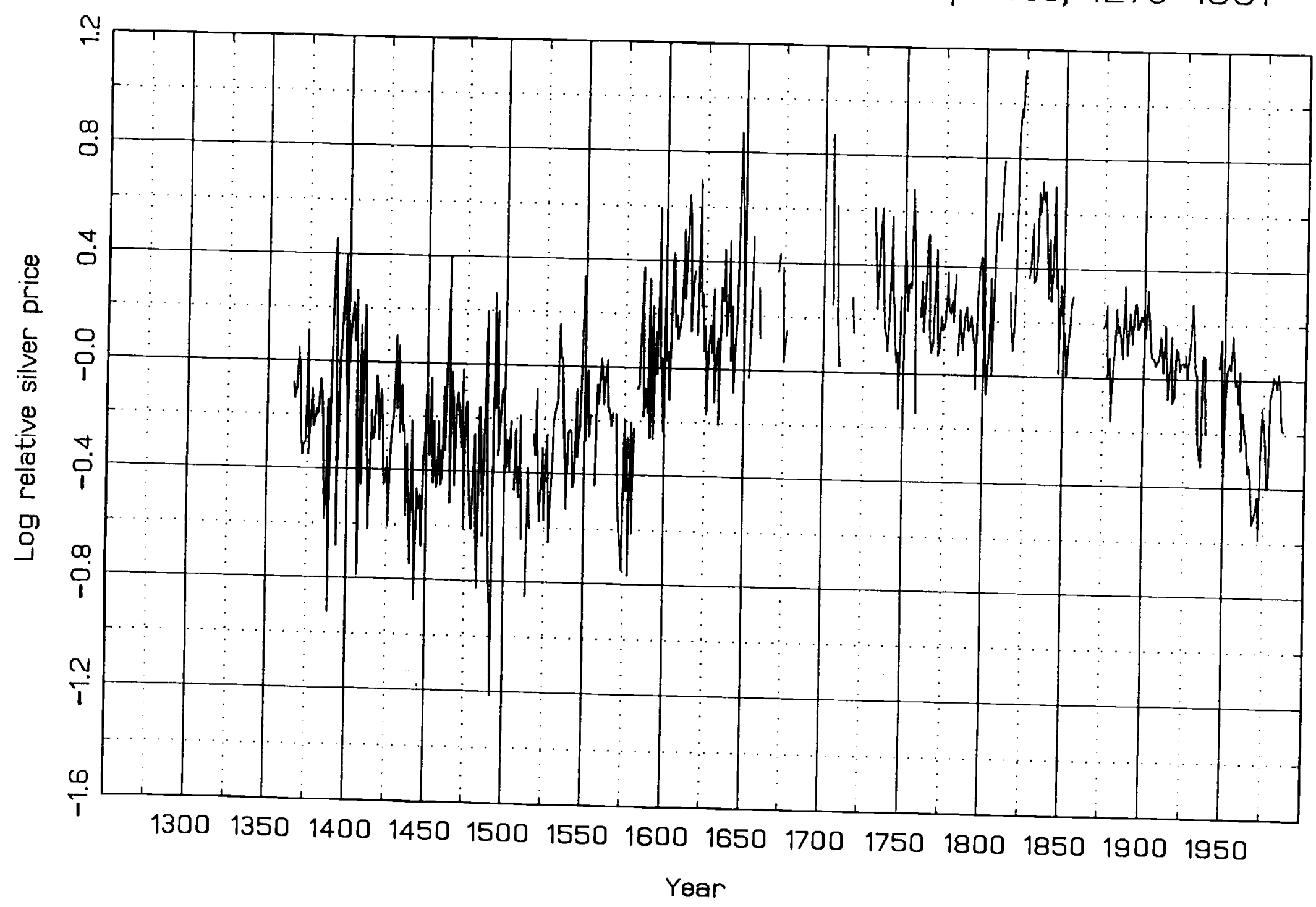




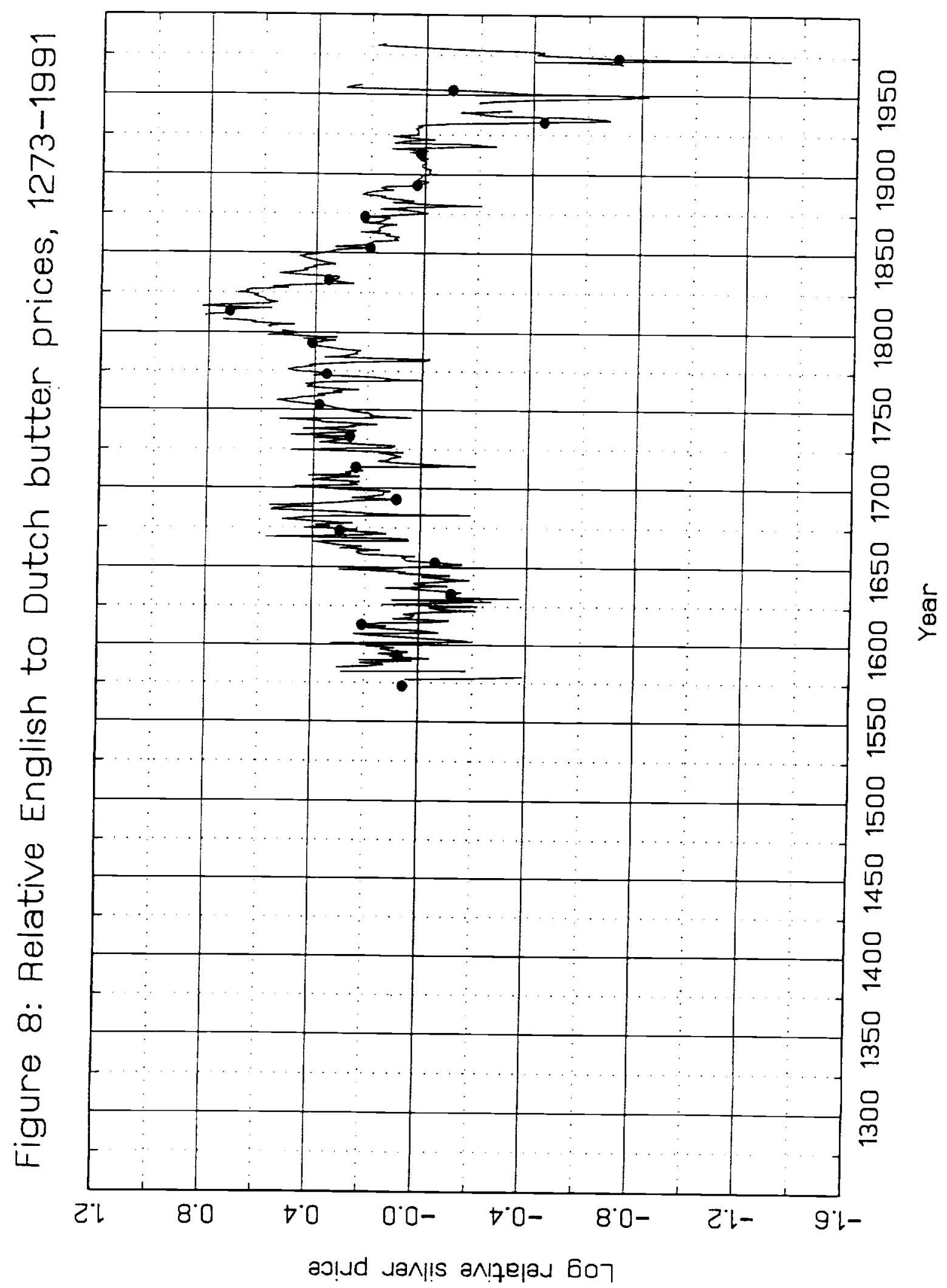


Figure 9: English butter, cheese and eggs prices measures relative to English wheat, 1273-1991

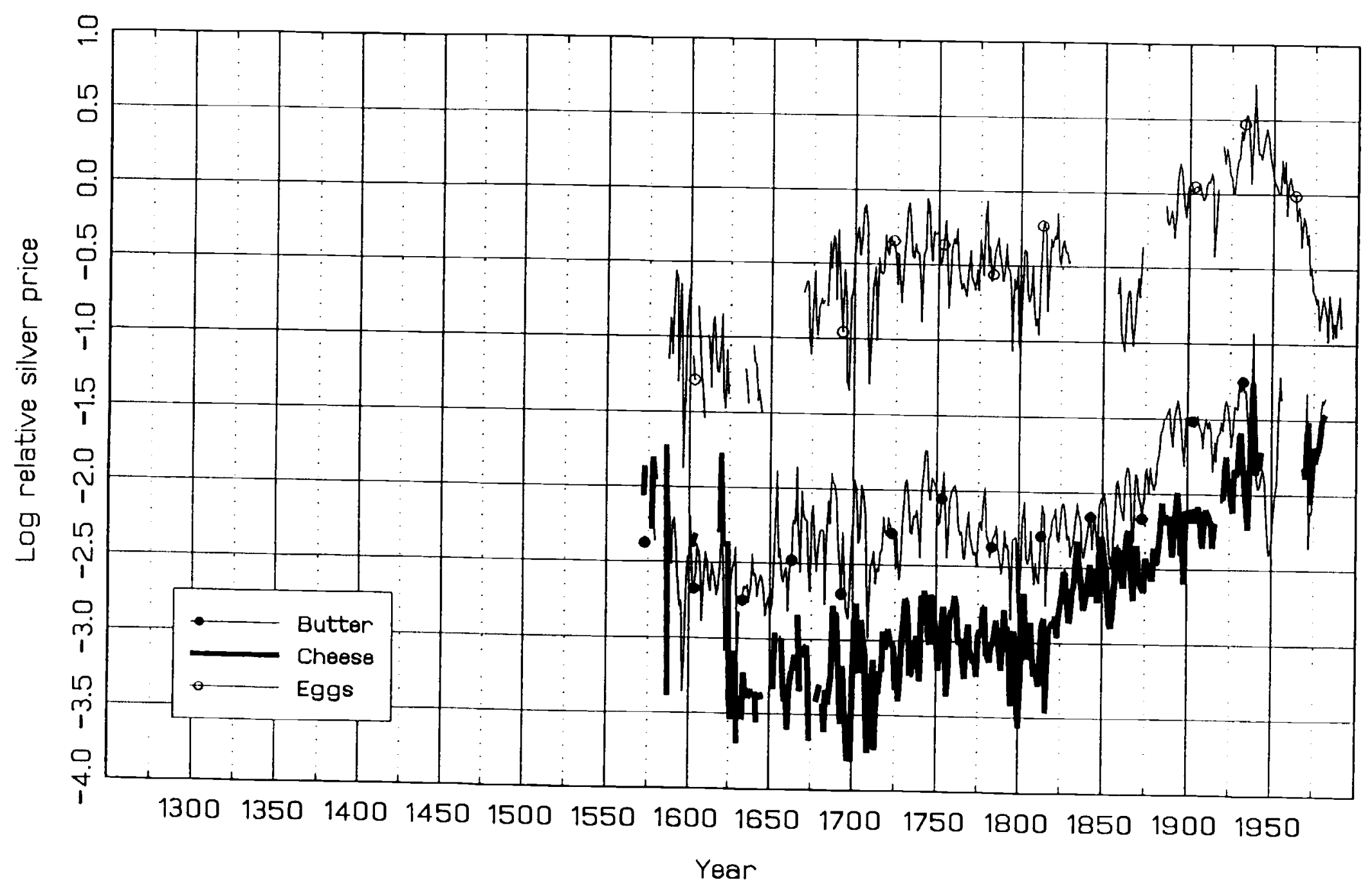




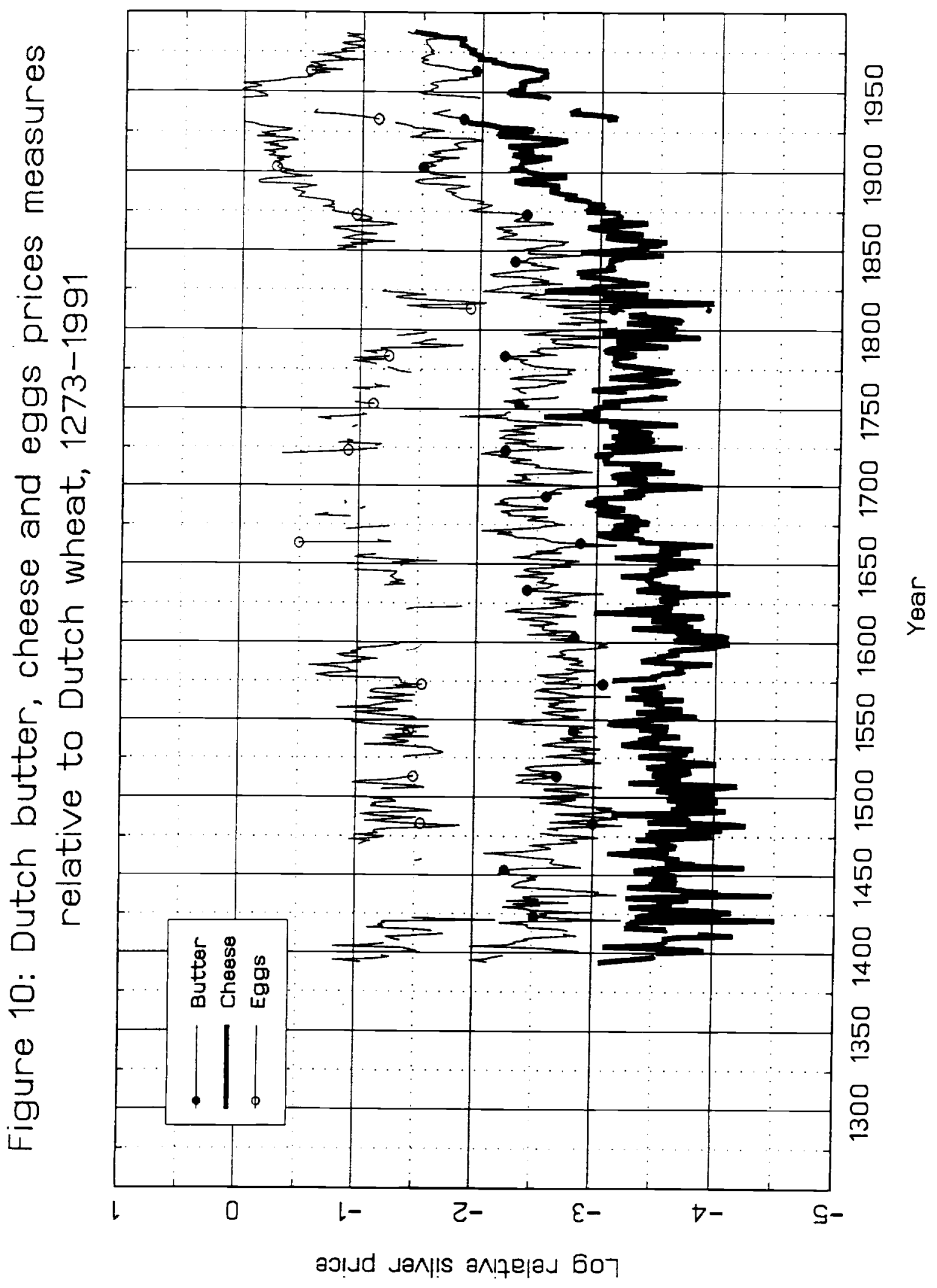




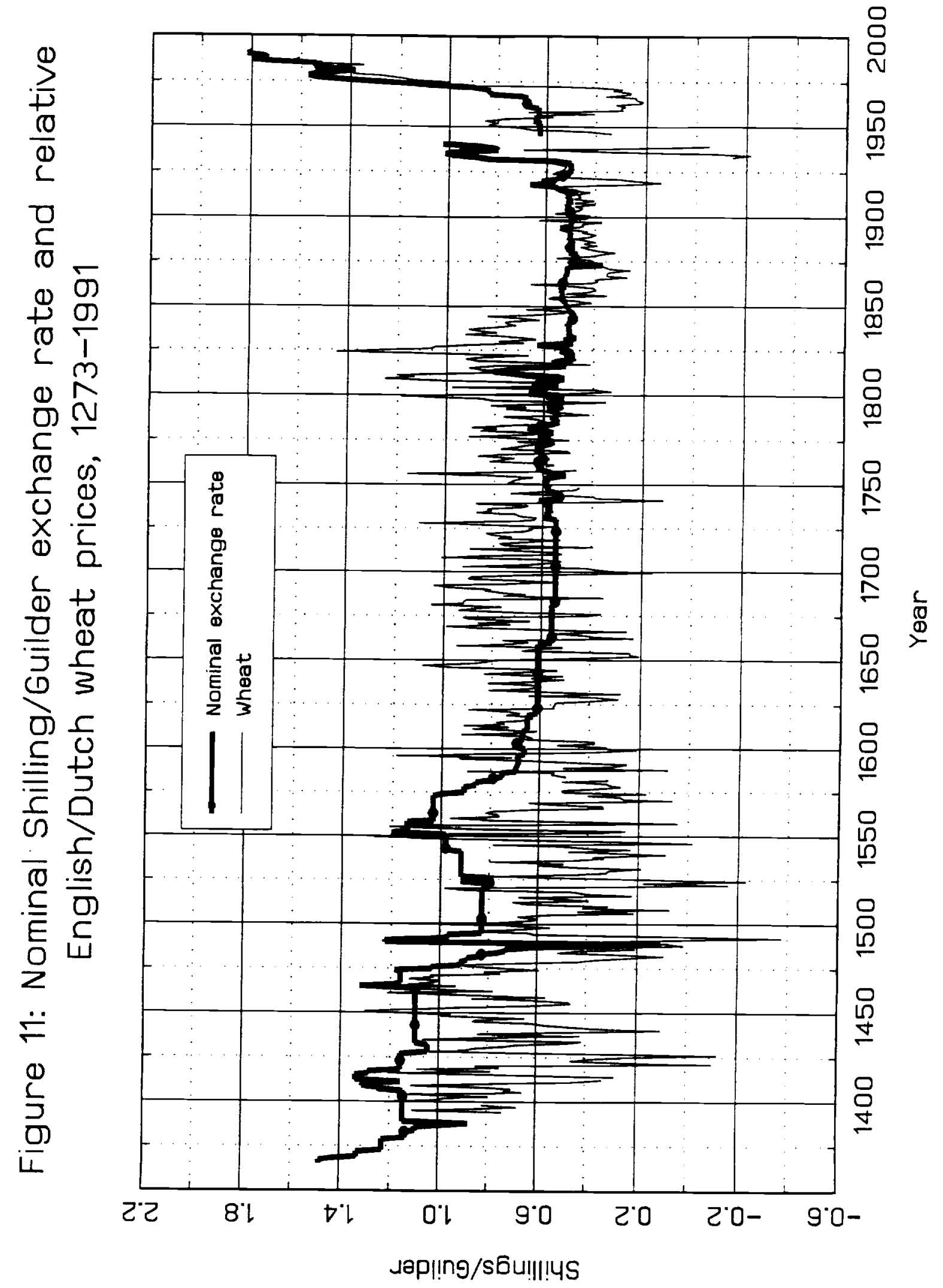

